\title{
PROYEKSI JANGKA PANJANG KEBUTUHAN ENERGI SULAWESI SELATAN MENGGUNAKAN SKENARIO SISTEM ENERGI BERSIH
}

\author{
Tesis \\ untuk memenuhi sebagian persyaratan \\ mencapai derajat Sarjana S-2
}

Program Studi Magister Teknik Sistem

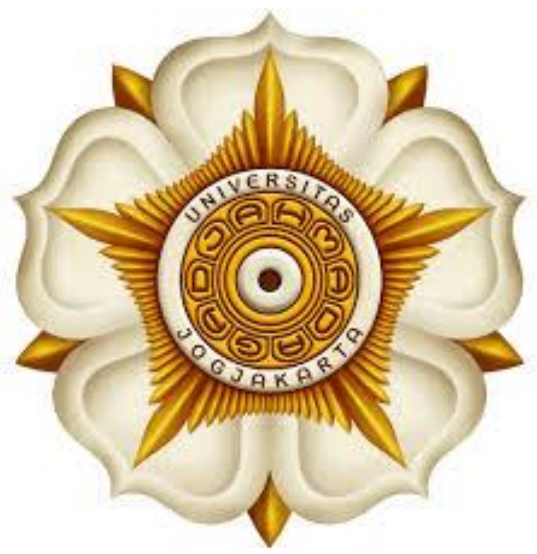

diajukan oleh

Rishal Asri

14/373847/PTK/9990

kepada

PROGRAM PASCASARJANA FAKULTAS TEKNIK

UNIVERSITAS GADJAH MADA

YOGYAKARTA 


\section{TESIS}

"PROYEKSI JANGKA PANJANG KEBUTUHAN ENERGI SULAWESI SELATAN MENGGUNAKAN SKENARIO SISTEM ENERGI BERSIH"

dipersiapkan dan disusun oleh

Rishal Asri

14/373847/PTK/9990

Telah dipertahankan di depan Dewan Penguji

Pada tanggal. I5... Februari.2016

Susunan Dewan Penguji

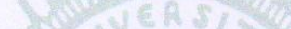

Pembimbing Utama

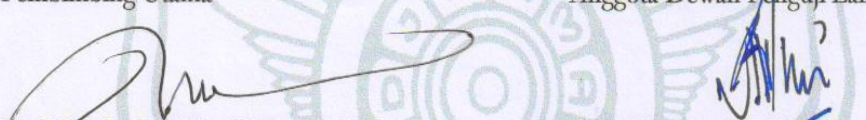

Rrof. Dr. Ir. Tarcisius Haryono, M.Sc $\quad$ Prof. Dr.Eng. Ir. Arief Budiman, M.S.

Pembimbing Pendamping

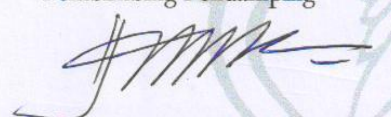

Dr.Eng. Mohammad Kholid Ridwan, S.T, M.Sc

Tesis ini telah diterima sebagai salah satu persyaratan Untuk memperoleh gelar Magister

Tanggal .29...Februari 2016

Ketua Program Studi Magister Teknik Sistem

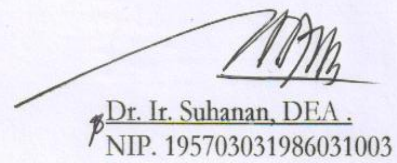

Mengetahui,

Ketua Unit Pengelola Program Pascasarjana Fakultas Teknik

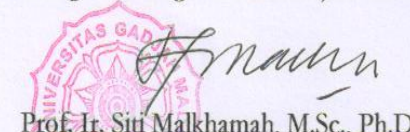

Prof. It. Siti Malkhamah, M.Sc. Ph.D

NIP. 196305021988032001 


\section{KATA PENGANTAR}

Syukur Alhamdulillah penulis panjatkan kehadirat Allah SWT. Atas limpahan rahmat, nikmat, dan karunia-Nya sehingga penulisan tesis ini dapat diselesaikan. Tesis ini ditulis untuk memenuhi persyaratan mencapai derajat sarjana S-2 Program Studi Magister Teknik Sistem (MTS), Konsentrasi Teknik Sistem Energi, Fakultas Teknik, Sekolah Pascasarjana, Universitas Gadjah Mada Yogyakarta.

Selesainya penulisan tesis yang berjudul "Proyeksi Jangka Panjang Kebutuhan Energi Sulawesi Selatan Menggunakan Skenario Sistem Energi Bersih" tidak terlepas dari bantuan berbagai pihak, untuk itu pada kesempatan ini, penulis ingin menyampaikan ucapan serta rasa terima kasih yang sangat mendalam kepada :

1. Prof. Ir. Panut Mulyono, M.Eng., Dr.Eng. selaku Dekan Fakultas Teknik Universitas Gadjah Mada Yogyakarta.

2. Prof. Ir. Siti Malkhamah, M.Sc., Ph.D. selaku Ketua Pascasarjana Fakultas Teknik Universitas Gadjah Mada

3. Dr. Ir. Suhanan, DEA., selaku Ketua Program Studi Magister Teknik Sistem, Fakultas Teknik, Universitas Gadjah Mada Yogyakarta

4. Prof. Dr. Ir. Tarcisius Haryono, M.Sc., selaku pembimbing utama yang telah memberikan bimbingan dari awal hingga selesainya penulisan tesis ini.

5. Dr.Eng. Mohamaad Kholid Ridwan, S.T., M.Sc., selaku pembimbing pendamping yang telah memberikan bimbingan dari awal hingga selesainya penulisan tesis ini.

6. Prof. Dr.Eng. Ir. Arief Budiman, M.S., selaku penguji utama yang telah bersedia meluangkan waktu dan memberikan pengarahan dan masukan untuk kesempurnaan penelitian

7. Bapak dan Ibu Dosen pada Magister Teknik Sistem yang telah memberikan wawasan pengetahuan dan keilmuan.

8. Seluruh Pengelola Magister Teknik Sistem Universitas Gadjah Mada, atas kerja sama yang baik selama masa studi 
9. Kepada Ayahanda M. Asri K, Ibunda Normah S, dan calon Istri Santi Rahim yang selalu memberikan dukungan penuh dalam penulisan tesis ini

10. Rekan-rekan Magister Teknik Sistem angkatan 2014 Abdul, Andika, Arie, Mitha, Diah, Lukman, Faziri, Fadhillah, Ismanto, Kezia, Mega, Qurnia, Siska, Vicky, Wahyu, dan seluruh rekan MTS lainnya.

11. Rekan-rekan Himpunan Mahasiswa Muslim Pascasarjan (HIMMPAS) Universitas Gadjah Mada

12. Pimpinan dan staf ESDM provinsi Sulawesi Selatan

13. Pimpinan dan staf PT. PLN Persero Sulselrabar

14. Pimpinan dan staf PT. Pertamina VII Makassar

15. Pimpinan dan staf BPS provinsi Sulawesi Selatan

16. Semua pihak yang tidak dapat penulis sebutkan, yang secara tidak langsung telah membantu, baik moral maupun materi dalam penyusunan tesis ini.

Semoga Allah SWT membalas semua kebaikan dan menjadikannya amal sholeh atas segala bantuan. Penulis menyadari bahwa tesis ini masih jauh dari sempurna, untuk itu sumbangan pemikiran, saran, dan kritik membangun dari para pembaca sangat penulis harapkan. Semoga hasil penelitian yang sederhana ini dapat memberi manfaat bagi pihak-pihak yang memerlukannya.

Yogyakarta, Februari 2016

Rishal Asri 


\section{PERNYATAAN}

Dengan ini saya menyatakan bahwa tesis ini tidak terdapat karya yang pernah diajukan untuk memperoleh gelar kesarjanaan di suatu Perguruan Tinggi, dan sepanjang pengetahuan saya tidak terdapat karya atau pendapat yang pernah ditulis atau diterbitkan oleh orang lain, kecuali yang secara tertulis diacu dalam naskah ini dan disebutkan dalam daftar pustaka.

Februari, 2016

Rishal Asri 


\section{DAFTAR ISI}

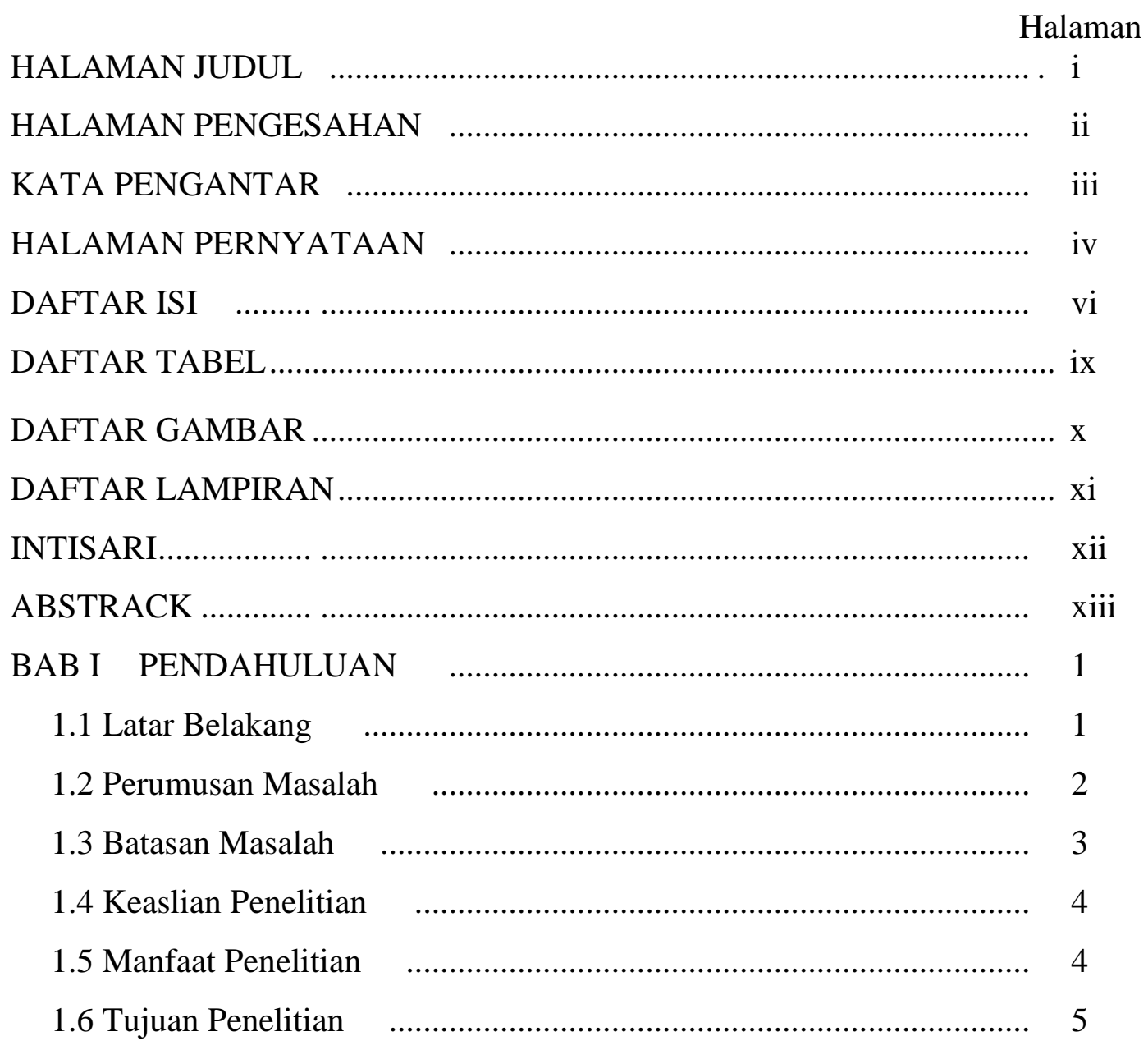

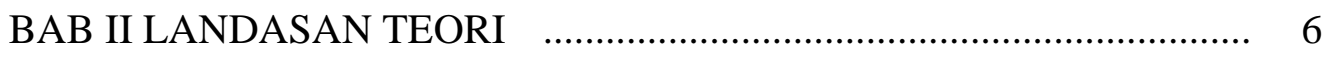

2.1 Tinjauan Pustaka ...................................................................... 6

2.2 Landasan Teori $\quad$...................................................................... 9

2.2.1 Konsep Clean Energy ...................................................... 9

2.2.2 Konsep Prakiraaan Permintaan Energi ................................. 9

2.2.3 Dasar Pembuatan Model ..................................................... 10

2.2.4 Model Peramalan/proyeksi .................................................. 13

2.2.5 Perangkat Lunak LEAP .................................................. 16

2.2.6 Pola Kebutuhan Energi ...................................................... 13

2.2.6.1 Sektor Pemerintah .................................................... 17

2.2.6.2 Sektor Rumah Tangga........................................... 17 
2.2.6.3 Sektor Komersial................................................. 18

2.2.6.4 Sektor Industri Besar dan Kecil ................................. 18

2.2.6.5 Sektor Transportasi ................................................. 19

2.2.7 Pola Penyediaan Energi ......................................................... 19

2.2.7.1 Batu Bara............................................................... 21

2.2.7.2 Minyak Mentah ...................................................... 21

2.2.7.3 Gas Bumi............................................................. 22

2.2.7.4 Energi Terbarukan................................................. 22

2.3 Hipotesis ................................................................................. 23

BAB III METODE PENELITIAN ～.................................................... 24

3.1 Data Penelitian ....................................................................... 24

3.2 Alat Penelitian ..................................................................... 25

3.3 Tata Laksana Penelitian $\quad$........................................................ 26

BAB IV HASIL PENELITIAN DAN PEMBAHASAN $\quad$....................... 29

4.1 Kondisi Sosial Ekonomi ............................................................ 29

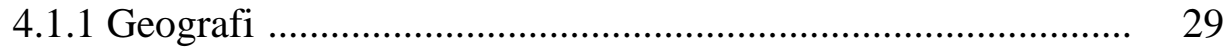

4.1.2 Populasi Penduduk ............................................................... 30

4.1.3 Produk Domestik Regional Bruto .......................................... 31

4.2 Kondisi Energi Sulawesi Selatan ............................................... 33

4.2.1 Minyak dan Gas Bumi ........................................................ 33

4.2.2 Batu Bara .......................................................................... 33

4.2.3 Energi Baru Terbarukan ...................................................... 34

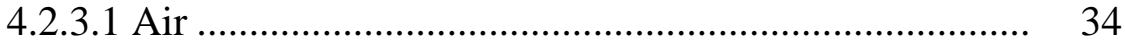

4.2.3.2 Panas Bumi................................................................ 34

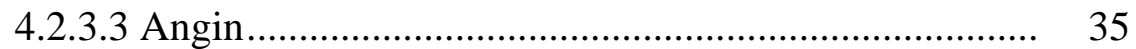

4.2.3.4 Surya ............................................................... 36

4.2.3.1 Biodiesel......................................................... 37

4.2.3.2 Bioetanol ......................................................... 38

4.2.3.1 Biogas ............................................................... $\quad 38$ 
4.2.3.2 Biomassa ..................................................... 38

4.2.4 Ketenagalistrikan ......................................................... 39

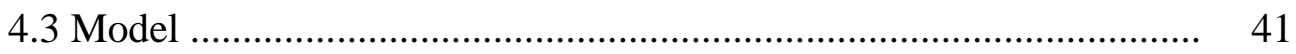

4.3.1 Asumsi Dasar ................................................................... 42

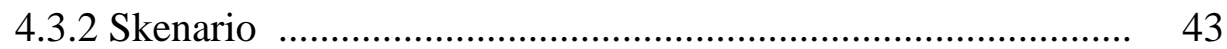

4.4 Proyeksi Konsumsi Energi Per Sektor ........................................... 45

4.4.1 Konsumsi Energi Sektor Rumah Tangga .............................. 47

4.4.2 Konsumsi Energi Sektor Industri ...................................... 50

4.4.3 Konsumsi Energi Sektor Transportasi ................................. 53

4.4.4 Konsumsi Energi Sektor Komersial..................................... 58

4.4.5 Konsumsi Energi Sektor Lain ............................................ 60

4.5 Proyeksi Penyediaan Energi ....................................................... 62

4.5.1 Pembangkit Listrik ........................................................... 62

4.5.2 Tambang Gas Bumi ........................................................ 68

4.6 Neraca Energi .......................................................................... 70

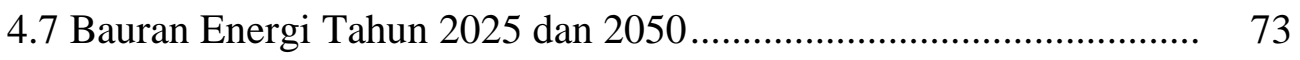

4.8 Sekuritas Energi ........................................................................ 74

BAB V KESIMPULAN DAN SARAN _........................................ 75

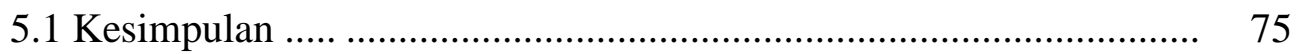

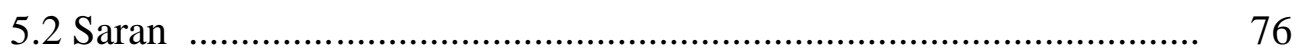

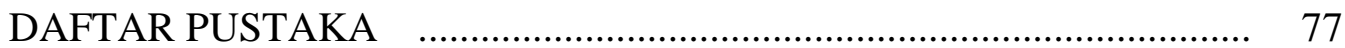

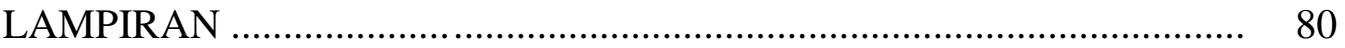


DAFTAR TABEL

Halaman

Tabel 1.1 Sasaran Energi Tahun 2025-2050 (Draft KEN-DEN) ..............4

Tabel 2.1 Penelitian Mengenai Proyeksi Energi ........................................ 7

Tabel 2.2 Perbandingan Perangkat Lunak Sistem Energi ...................... 15

Tabel 4.1 Rencana Pembangkit Listrik Sulawesi Selatan .........................41

Tabel 4.2 Perbandingan Skenario ........................................................4

Tabel 4.3 Proyeksi Konsumsi Energi Per Sektor .....................................46

Tabel 4.4 Konsumsi Energi Jenis Sektor Rumah Tangga Skenario BaU . 48

Tabel 4.5 Konsumsi Energi Jenis Sektor Rumah Tangga Skenario CE ...49

Tabel 4.6 Konsumsi Energi Jenis Sektor Industri...................................51

Tabel 4.7 Konsumsi Energi Jenis Sektor Transportasi Skenario BaU ......54

Tabel 4.8 Konsumsi Energi Jenis Sektor Transportasi Skenarion CE......57

Tabel 4.9 Konsumsi Energi Jenis Sektor Komersial..............................59

Tabel 4.10 Konsumsi Energi Jenis Sektor Lain .......................................61

Tabel 4.11 Proyeksi Energi Jenis Sektor Pembangkit Skenario BaU .......64

Tabel 4.12 Proyeksi Energi Jenis Sektor Pembangkit Skenario CE .........66

Tabel 4.13 Produksi LNG Skenario CE .................................................69

Tabel 4.14 Neraca Energi Sulawesi Selatan Tahun 2014 Skenario BaU.. 72

Tabel 4.15 Bauran Energi Sulawesi Selatan ......................................... 73

Tabel 4.16 Perbandingan Energy Security Skenario BaU dan CE............75 


\section{DAFTAR GAMBAR}

Halaman

Gambar 2.1 Kebutuhan Energi Indonesia Per Sektor ............................. 17

Gambar 2.2 Penyediaan Energi Indonesia ............................................20

Gambar 3.1 LEAP Versi 2015.0.8.0 …...............................................25

Gambar 3.2 Metode dan Alur Penelitian .............................................28

Gambar 4.1 Peta Provinsi Sulawesi Selatan ............................................2.29

Gambar 4.2 Perbandingan PDRB per Kapit dan PDRB Harga Konstan ..32

Gambar 4.3 Pertumbuhan PDRB Atas Dasar Harga Konstan .................. 32

Gambar 4.4 Konsumsi Energi Jenis BBM ............................................ 33

Gambar 4.5 Peta Potensi Panas Bumi Sulawesi Selatan........................... 35

Gambar 4.6 Peta Potensi Angin Sulawesi Selatan .................................... 36

Gambar 4.7 Model LEAP Energi Sulawesi Selatan.................................42

Gambar 4.8 Proyeksi Penggunaan Energi Total Per Sektor ....................45

Gambar 4.9 Bauran Energi Nasional ....................................................46

Gambar 4.10 Konsumsi Energi Sektor Rumah Tangga Skenario BaU ....47

Gambar 4.11 Konsumsi Energi Sektor Rumah Tangga Skenario CE.......48

Gambar 4.12 Konsumsi Energi Sektor Rumah Tangga Nasional.............49

Gambar 4.13 Konsumsi Energi Sektor Industri .....................................51

Gambar 4.14 Konsumsi Energi Sektor Industri Nasional........................53

Gambar 4.15 Konsumsi Energi Sektor Transportasi Skenario BaU .........54

Gambar 4.16 Konsumsi Energi Sektor Transportasi Skenario CE ...........56

Gambar 4.17 Konsumsi Energi Sektor Transportasi Nasional .................58

Gambar 4.18 Konsumsi Energi Sektor Komersial .................................59

Gambar 4.19 Konsumsi Energi Sektor Komersial Nasional....................60

Gambar 4.20 Konsumsi Energi Sektor Lain ...........................................61

Gambar 4.21 Konsumsi Energi Sektor Lain Nasional ............................62

Gambar 4.22 Peta Kelistrikan Sulawesi Selatan ......................................6 63

Gambar 4.23 Proyeksi pembangkit listrik skenario BaU .........................64

Gambar 4.24 Proyeksi pembangkit listrik skenario CE ...........................66

Gambar 4.25 Proyeksi pembangkit Nasional ........................................6 68

Gambar 4.26 Produksi Kilang LNG Skenario CE .................................69

Gambar 4.27 Proyeksi Pemakaian Gas Pada Setiap Sektor ...................... 70 


\section{DAFTAR LAMPIRAN}

Halaman

Lampiran 1 Pemakaian Bahan Bakar Gas............................................ 81

Lampiran 2 Energy Balance 2025 Scenario BaU .................................8 82

Lampiran 3 Energy Balance 2025 Scenario CE ......................................8 83

Lampiran 4 Energy Balance 2050 Scenario BaU .................................. 84

Lampiran 5 Energy Balance 2050 Scenario CE ....................................85

Lampiran 6 Energy Flow 2025 Scenario BaU .......................................86

Lampiran 7 Energy Flow 2025 Scenario CE ........................................8 87

Lampiran 8 Energy Flow 2050 Scenario BaU ..................................... 88

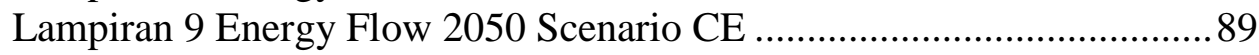

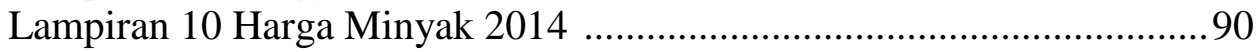

Lampiran 11 Konversi Satuan Energi .................................................91

Lampiran 12 Data Kependudukan dan Data Ekonomi .........................992

Lampiran 13 Pemakaian Energi BBM dan PLTA .................................93

Lampiran 14 PLTMH Sulawesi Selatan .............................................. 94

Lampiran 15 PLTS Sulawesi Selatan ...................................................95

Lampiran 16 Potensi Biodiesel dan Bioetanol Sulawesi Selatan .............96

Lampiran 17 Potensi Biogas Sulawesi Selatan ..................................... 97

Lampiran 18 Potensi Biomassa dan Pemakaian Energi Listrik ..............99

Lampiran 19 Pembangkit Listrik Sulawesi Selatan ............................... 100

Lampiran 20 Konversi Satuan Energi SBM ........................................ 101 


\section{INTI SARI}

Provinsi Sulawesi Selatan merupakan salah satu pulau terbesar di Indonesia. Kebutuhan energi seperti listrik dan transportasi merupakan penggerak roda ekonomi suatu daerah. Kebutuhan energi Sulawesi selatan sebanyak 17.000 SBM (Setara Barel Minyak) dengan pemenuhan 3.000 SBM yang berasal dari sumber energi domestik dan 14.000 SBM harus diimpor. Pemerintah Indonesia memiliki kebijakan energi nasioanl pada tahun 2025 bauran energi untuk energi terbarukan terbesar sebesar 23\% dan tahun 2050 sebesar $31 \%$. Pada penelitian ini bertujuan untuk meningkatkan proyeksi penggunaan energi terbarukan sesuai dengan arah kebijakan energi nasional. Data yang digunakan adala produk domestic regional bruto, konsumsi listrik, konsumsi bahan bakar minyak, dan indikator energi lainnya. Pada penelitian ini meggunakan LEAP untuk memodelkan dan memprediksi kebutuhan energi. Dari hasil penelitian ini pada tahun 2050 sumber energi fosil untuk kebutuhan energi yang digunakan adalah minyak bumi sebesar 80,21 juta SBM, batu bara 27 juta SBM, dan gas alam 14,28 SBM sedangkan energi terbarukan hanya 23,1 juta SBM.

Kata Kunci : Sulawesi Selatan, energi ,LEAP,listrik, prediksi 


\begin{abstract}
ABSTRACK
South Sulawesi province is one of the largest island in Indonesia. Energy needs such as electricity and transportation are driving the economy of a region. The energy needs of southern Sulawesi which are 17,000 BOE (Barrel of Oil Equivalent) to 3,000 BOE in coming from domestic energy sources and 14,000 $B O E$ to be imported. The Indonesian government has a national energy policy by 2025 energy mix for the largest renewable energy with be $23 \%$ and in 2050 with be $31 \%$. This study aims to increase the projected use of renewable energy in accordance with the direction of the national energy policy. The data used was gross regional domestic product, electricity consumption, consumption of fuel oil and other energy indicators. In this study LEAP receipts for modeling and forecasting the energy requirements. From the results of this study in 2050 fossil energy sources for the needs of the energy used is petroleum amounted to 80.21 million BOE, 27 million BOE coal, and natural gas 14.28 million BOE of renewable energy while only 23.1 million $B O E$.
\end{abstract}

Keywords: South Sulawesi. Energy, LEAP, Electricity, forecasting 


\section{BAB I}

\section{PENDAHULUAN}

\subsection{Latar Belakang}

Untuk mencapai pola pengelolaan energi diperlukan perubahan manajemen baik dari sisi demand maupun sisi supply energi. Pada kondisi saat ini telah diketahui bahwa permintaan penyediaan energi terus meningkat dari tahun ke tahun untuk mencukupi kebutuhan sektor rumah tangga, transportasi, industri maupun komersial. Di sisi lain, pemakaian energi pada masing-masing sektor tersebut masih jauh dari kriteria efisien sehingga pemakaian cenderung boros. Salah satu provinsi terbesar di Indonesia yaitu Sulawesi Selatan memiliki masalah utama yaitu kebutuhan dan pemenuhan energi.

Menurut Dinas Energi dan Sumber Daya Mineral provinsi Sulawesi Selatan ("Rencana Umum Energi Daerah Sulawesi Selatan," 2014) pada neraca energi menunjukkan bahwa produksi energi primernya lebih kecil dari pada penggunaan energi final. Kebutuhan energi primer pada tahun 2006 sebesar 17,293 ribu SBM yang disuplai dari potensi daerah domestik sebesar 2,998 ribu SBM hal ini karena energi yang dapat disuplai hanya energi gas alam sebesar 1,493 ribu SBM, energi matahari sebesar 2 ribu SBM dan energi Air sebesar 1,503 ribu SBM. Sedangkan sisanya perlu diadakan impor atau suplai dari luar provinsi Sulawesi Selatan sebesar 14,295 ribu SBM.

Pemerintah lebih terfokus dalam penggunaan sumber energi fosil untuk mencukupi kebutuhan energi primer. Pemanfaatan sumber energi terbarukan hanya dipakai sebagai energi alternatif dan tidak mendapat porsi perhatian yang 
lebih besar walaupun lebih menjanjikan dari segi potensi maupun keramahan terhadap lingkungan. Maka perubahan manajemen pengelolaan energi harus diubah demi menjaga keamanan pasokan dan ketahanan energi nasional.

Perubahan ini meliputi perubahan sisi demand maupun sisi supply. Dari sisi demand, diperlukan upaya konservasi energi untuk pemakaian energi yang lebih efisien serta menggunakan teknologi hemat energi. Sedangkan dari sisi supply, diperlukan sebuah kebijakan diversifikasi sumber energi terbarukan untuk memaksimalkan penyediaan dan pemanfaatan energi dengan menjadikan energi fosil sebagai faktor penyeimbang. Ketersediaan energi merupakan parameter dan aspek yang penting bagi keberhasilan pembangunan daerah.

\subsection{Perumusan Masalah}

Dari uraian di atas maka perumusan masalah dapat diidentifikasikan adalah menentukan gambaran masa depan terkait pemakaian dan penyediaan energi serta menentukan bauran energi di provinsi Sulawesi Selatan. Pada sistem energi dapat diuraikan lebih terperinci yaitu keseimbangan permintaan dan penyediaan energi, besar sharing energi terbarukan terhadap penyediaan energi dan langkah-langkah yang dapat diambil untuk menerapkan sistem energi bersih.

\subsection{Batasan Masalah}

Dalam penelitian ini akan dilakukan perencanaan permintaan energi di provinsi Sulawesi Selatan. Ada pun yang menjadi lingkup kajian atau batasan masalah dalam penelitian ini adalah :

a. Sistem Energi Provinsi Sulawesi Selatan. 
b. Data dasar untuk proyeksi adalah data tahun 2014 .

c. Proyeksi dilakukan adalah data tahun 2014- 2025 dan tahun 20142050.

d. Efek lingkungan tidak dibahas dalam penelitian ini.

Penentuan batas akhir proyeksi tahun 2025 dan tahun 2050 diadakan untuk mengikuti Kebijakan Energi Nasional (KEN) yang disusun pada tahun tersebut sebagai pedoman untuk memberi arah pengelolaan energi guna mewujudkan kemandirian dan ketahanan energi guna mendukung pembangunan nasional dengan terwujudnya bauran energi primer dengan peranan masing-masing jenis energi pada tahun 2025 sebagai berikut:

- Minyak bumi menjadi kurang dari 20 persen.

- Gas bumi menjadi lebih dari 30 persen

- Batu Bara menjadi lebih dari 33 persen.

- Bahan bakar nabati menjadi lebih dari 5 persen.

- Panas bumi mejadi lebih dari 5 persen.

- Biomassa, nuklir, mikrohidro, tenaga surya,dan tenaga angin menjadi 5 persen.

- Batu bara yang dicairkan menjadi lebih dari 2 persen.

Proyeksi menggunakan tahun 2050 untuk mencapai sasaran di bidang penyediaan energi primer, pemanfaatan energi primer per kapita, penyediaan kapasitas pembangkit dan pemanfaatan listrik per kapita. Pada tabel 1.1 diuraikan target tahun 2025 dan tahun 2050 . 
Tabel 1.1 Sasaran Energi pada tahun 2025-2050 (Draft KEN-DEN)

\begin{tabular}{|l|c|c|c|}
\hline \multicolumn{1}{|c|}{ Sasaran } & Satuan & Tahun 2025 & Tahun 2050 \\
\hline Penyediaan energi primer & MTOE & 400 & 1.000 \\
\hline $\begin{array}{l}\text { Pemanfaatan energi } \\
\text { primer per kapita }\end{array}$ & TOE & 1,4 & 3,2 \\
\hline Penyediaan kapasitas pembangkit & GW & 115 & 430 \\
\hline Pemanfaatan listrik per kapita & $\mathrm{kWh}$ & 2.500 & 7000 \\
\hline
\end{tabular}

Dalam melakukan analisis permintaan energi digunakan alat bantu yang berupa perangkat lunak komputer yaitu LEAP ( Long-range Energi Alternative Planning system ). Metode perhitungan dalam LEAP didasarkan pada perhitungan analitis end use.

\subsection{Keaslian penelitian}

Dari hasil studi pustaka hingga saat ini belum pernah ada penelitian yang dilakukan atau ditemukan serupa dengan penelitian mengenai pemetaan dan perencanaan konsumsi energi di provinsi Sulawesi Selatan serta penerapan sistem energi bersih.

\subsection{Manfaat Penelitian}

Hasil penelitian ini dapat membantu pemerintah di provinsi Sulawesi Selatan dalam membuat perencanaan energi daerah seperti diamanatkan dalam Undang-undang No. 30 tahun 2007 tentang energi, serta dapat menjadi masukan dalam pengembangan teknologi energi di provinsi Sulawesi Selatan. 


\subsection{Tujuan Penelitian}

Tujuan penelitian ini adalah :

a. Menentukan proyeksi permintaan dan penyediaan energi per sektor pemakai dan per jenis di provinsi Sulawesi Selatan.

b. Menentukan proyeksi bauran energi di provinsi Sulawesi Selatan

c. Menentukan besar sharing energi terbarukan terhadap pemenuhan energi di provinsi Sulawesi Selatan.

d. Menentukan Energy Security atau ketahanan energi di provinsi Sulawesi Selatan 


\section{BAB II}

\section{LANDASAN TEORI}

\subsection{Tinjauan Pustaka}

Menurut Huang, Bor, \& Peng (2011) metode forecasting data menggunakan LEAP untuk memprediksi kebutuhan energi di Taiwan atau pun di negara lain sangat berbeda sehingga dibutuhkan perencanaan yang membutuhkan waktu dan skenario energi yang berbeda. Dengan menggunakan LEAP, kebutuhan tiap negara atau daerah dapat ditunjukkan keuntungan dan kekurangan tiap penggunaan sumber energi terhadap lingkungan di sekitarnya.

Penelitian Manjang, Arief, \& Kitta (2013) menunjukkan kebutuhan energi listrik di provinsi Sulawesi Selatan pada suatu desa. Survei data dan analisis data menggunakan LEAP yang akan menghasilkan prediksi pemakaian dan penyedian energi listrik di Sulawesi Selatan. Untuk menggunakan energi terbarukan sebagai energi utama untuk mensuplai kebutuhan energi listrik pada suatu desa, maka perlu teknologi energi terbarukan seperti matahari, angin, dan air yang dapat dikonversi menjadi energi listrik

Menurut Putra, Tuegeh, Tumaliang, \& Patras (2014) untuk dapat memenuhi kebutuhan listrik di provinsi Sulawesi Selatan perlu dibangun pembangkit listrik secara bertahap dan penambahan kapasitas sebesar 330 MW. Provinsi Sulawesi Selatan memiliki banyak potensi energi primer yang dapat dimanfaatkan sebagai alternatif pengembangan pembangkit listrik, diantaranya: energi air yang dapat dimanfaatkan menjadi PLTA yang mempunyai kapasistas 1,835.8 MW dan PLTM sebesar 68.84 MW, gas alam dengan cadangan 
terukur sebesar 377.3 BSCF, batu bara dengan cadangan terukur 5.2 juta ton dan panas bumi dengan kapasitas mencapai 1,950 MW.

Menurut Roinioti, Koroneos, \& Wangensteen (2012) pada penelitian tentang sistem energi Yunani dilakukan skenario Clean Energy atau energi bersih. Di dalam skenario bersih menghasilkan prosentasi penggunaan energi terbarukan sebesar 23,9 \% dan penurunan penggunaan bahan bakar fosil minyak 20 MTOE. Pada tabel 2.1 ditunjukkan beberapa penelitan mengenai proyeksi energi.

Tabel 2.1 Penelitian Mengenai Proyeksi Energi

\begin{tabular}{|l|l|l|l|}
\hline No & Peneliti & Judul Penelitian & Hasil Penelitian \\
\hline 1 & $\begin{array}{l}\text { Saddler, Diesendorf, } \\
\text { \& Denniss (2007) }\end{array}$ & $\begin{array}{l}\text { Clean energy } \\
\text { scenarios for } \\
\text { Australia }\end{array}$ & $\begin{array}{l}\text { Penggunaan skenario energi } \\
\text { bersih yang dapat menghemat } \\
\text { penggunaan energi secara } \\
\text { ekonomi dengan tambahan } \\
\text { biaya pada penggunaan energi } \\
\text { terbarukan dan gas }\end{array}$ \\
\hline 2 & $\begin{array}{l}\text { Mondal, Boie, \& } \\
\text { Denich (2010) }\end{array}$ & $\begin{array}{l}\text { Future demand } \\
\text { scenarios of } \\
\text { Bangladesh power } \\
\text { sector }\end{array}$ & $\begin{array}{l}\text { Peramalan kebutuhan energi } \\
\text { listrik di Bangladesh } \\
\text { menghasilkan kenaikan } \\
\text { sebelas kali pada tahun 2035 }\end{array}$ \\
\hline 3 & $\begin{array}{l}\text { Huang, Bor, \& Peng } \\
\text { (2011) }\end{array}$ & $\begin{array}{l}\text { The long-term } \\
\text { forecast of Taiwan's } \\
\text { energy supply and } \\
\text { demand: LEAP } \\
\text { model application }\end{array}$ & $\begin{array}{l}\text { keuntungan dan kekurangan } \\
\text { tiap penggunaan sumber } \\
\text { energi di Taiwan terhadap } \\
\text { lingkungan di sekitarnya }\end{array}$ \\
\hline 4 & $\begin{array}{l}\text { Roinioti, Koroneos, } \\
\text { Wangensteen (2012) }\end{array}$ & $\begin{array}{l}\text { Modeling the Greek } \\
\text { energy system: } \\
\text { Scenarios of clean } \\
\text { energy use and their } \\
\text { implications }\end{array}$ & $\begin{array}{l}\text { Penggunaan energi di yunani } \\
\text { menggunakan perbandingan } \\
\text { lima skenario dengan skenario } \\
\text { terpilih adalah skenario biru }\end{array}$ \\
\hline
\end{tabular}


Tabel 2.1 Penelitian Mengenai Proyeksi Energi (lanjutan)

\begin{tabular}{|c|c|c|c|}
\hline No & Peneliti & Judul Penelitian & Hasil Penelitian \\
\hline 5 & $\begin{array}{l}\text { Manjang, Arief, \& } \\
\text { Kitta (2013) }\end{array}$ & $\begin{array}{l}\text { Optimalisasi } \\
\text { Penggunaan Energi } \\
\text { Terbarukan Lokal } \\
\text { Sebagai Energi } \\
\text { Primer Pembangkit } \\
\text { Tenaga Listrik Di } \\
\text { Sulawesi Selatan } \\
\text { Berbasis Skenario } \\
\text { Energi Mix Nasional }\end{array}$ & $\begin{array}{l}\text { Penggunaan energi terbarukan } \\
\text { sebagai energi utama yang } \\
\text { mensuplai kebutuhan energi } \\
\text { listrik pada suatu desa untuk } \\
\text { desa mandiri energi }\end{array}$ \\
\hline 6 & $\begin{array}{l}\text { Putra, Tuegeh, } \\
\text { Tumaliang, \& Patras } \\
(2014)\end{array}$ & $\begin{array}{l}\text { AnalisaPertumbuhan } \\
\text { Beban Terhadap } \\
\text { Ketersediaan Energi } \\
\text { Listrik di Sistem } \\
\text { Kelistrikan Sulawesi } \\
\text { Selatan }\end{array}$ & \begin{tabular}{lrr} 
untuk & dapat & \multicolumn{2}{r}{ memenuhi } \\
kebutuhan & listrik di & provinsi \\
Sulawesi & Selatan & perlu \\
dibangun & pembangkit & listrik \\
secara & bertahap & dan \\
penambahan kapasitas & sebesar \\
330 MW & &
\end{tabular} \\
\hline 7 & $\begin{array}{l}\text { Haryono \& } \\
\text { Deendarlianto (2014) }\end{array}$ & $\begin{array}{l}\text { Analisis } \\
\text { Keseimbangan } \\
\text { Energi Daerah } \\
\text { Istimewa } \\
\text { Yogyakarta }\end{array}$ & $\begin{array}{l}\text { Bauran energi Provinsi DIY } \\
\text { pada tahun } 2012 \text { sebesar } \\
0,07 \% \text { yang dapat meningkat } \\
\text { pada tahun } 2025 \text { sebesar } \\
0,53 \% \text { dengan menggunakan } \\
\text { energi terbarukan }\end{array}$ \\
\hline 8 & $\begin{array}{l}\text { Gómez, Dopazo, \& } \\
\text { Fueyo (2014) }\end{array}$ & $\begin{array}{l}\text { The causes of the } \\
\text { high energy } \\
\text { intensity of the } \\
\text { Kazakh economy: A } \\
\text { characterization of } \\
\text { its energy system }\end{array}$ & $\begin{array}{l}\text { Kebutuhan energi negara } \\
\text { Kazahktan yang paling besar } \\
\text { adalah pemanas pada tiap } \\
\text { bangunan dan penggunaan } \\
\text { sumber energi gas yang } \\
\text { kurang efisien untuk industri }\end{array}$ \\
\hline 9 & $\begin{array}{l}\text { McPherson \& Karney } \\
(2014)\end{array}$ & $\begin{array}{l}\text { Long-term scenario } \\
\text { alternatives and their } \\
\text { implications: LEAP } \\
\text { model application of } \\
\text { Panama's electricity } \\
\text { sector }\end{array}$ & $\begin{array}{l}\text { Penggunaan energi terbarukan } \\
\text { sebagai energi mix pada } \\
\text { negara Panama dapat } \\
\text { mengurangi penggunaan } \\
\text { energi fosil }\end{array}$ \\
\hline
\end{tabular}


Tabel 2.1 Penelitian Mengenai Proyeksi Energi (lanjutan)

\begin{tabular}{|l|ll|l|l|}
\hline No & Peneliti & Judul Penelitian & Hasil Penelitian \\
\hline 10 & $\begin{array}{l}\text { Kale \& Pohekar } \\
\text { (2014) }\end{array}$ & $\begin{array}{l}\text { Electricity demand } \\
\text { and supply scenarios } \\
\text { for Maharashtra } \\
\text { (India) for 2030: An } \\
\text { application of long } \\
\text { range energy } \\
\text { alternatives planning }\end{array}$ & $\begin{array}{l}\text { Negara bagian Maharashtra } \\
\text { menggunakan tiga skenario } \\
\text { untuk kebutuhan energi listrik } \\
\text { yaitu BAU, EC, REN dengan } \\
\text { skenario terpilih REN } \\
\text { lingkungan dampak }\end{array}$ \\
\hline 11 & Hongtao (2015) & $\begin{array}{l}\text { Clean-energy } \\
\text { policies and } \\
\text { electricity sector } \\
\text { carbon emissions in } \\
\text { the U.S. states }\end{array}$ & $\begin{array}{l}\text { Amerika serikat telah } \\
\text { melakukan kebijakan energi } \\
\text { bersih untuk mengurangi } \\
\text { penggunaan karbon pada } \\
\text { sistem kelistrikan }\end{array}$ \\
\hline
\end{tabular}

\subsection{Landasan Teori}

\subsubsection{Konsep Clean Energy}

Menurut Saddler, Diesendorf, \& Denniss (2007) konsep Clean Energy atau energi bersih adalah sebuah metode untuk menghasilkan energi yang lebih efisien dan lebih bersih. Energi yang lebih bersih adalah upaya untuk meningkatkan penggunaan teknologi energi baru dan terbarukan. Energi yang lebih efisisen adalah upaya untuk mengurangi biaya pada teknologi energi yang sudah ada misalnya energi fosil seperti batu bara, bahan bakar minyak, dan gas.

\subsubsection{Konsep Prakiraan Permintaan Energi}

Prakiraan energi merupakan bagian penting dalam penyusunan perencanaan energi disamping strategi penyediaannya. Secara umum beberapa faktor utama yang menentukan tingkat permintaan energi adalah pertumbuhan 
ekonomi (PDB), jumlah penduduk, harga energi dan konsumsi energi di masa lampau. Untuk membuat prakiraan permintaan energi, alat yang digunakan dapat berupa model energi yang merupakan model pola konsumsi energi di masa mendatang Berbagai model energi telah dikembangkan untuk membantu dalam perencanaan energi, antara lain model yang berdasarkan top down (ekonometrik) maupun bottom-up banyak digunakan untuk membuat prakiraan permintaan energi jangka panjang. Sedangkan untuk strategi penyediaan energi, banyak digunakan teknik optimasi dengan fungsi objektif tertentu atau dengan cara perhitungan/akuntansi biasa.

\subsubsection{Dasar Pembuatan Model}

Konsumsi energi di masa mendatang pada dasarnya merupakan pola konsumsi di masa lalu yang dipengaruhi oleh parameter baru yang kurang dominan. Oleh karena itu dasar pembuatan model dengan metode ekonometri banyak digunakan. Permintaan energi di setiap sektor dapat diklasifikasikan dalam permintaan energi dan non energi (bahan bakar), yang masing-masing diperkirakan memakai analisis regresi. Untuk estimasi energi listrik dengan regresi permintaannya dibagi dalam sektor industri, rumah tangga, komersial, dan publik, sedangkan untuk bahan bakar estimasi dilakukan dengan regresi dari tiap jenis bahan bakar dan satu yang digunakan sebagai sumber energi mix yang dihitung berdasarkan fungsi sharing. Ide umum pembuatan model prakiraan permintaan energi adalah sebagai berikut (Assauri, 1984).

$$
\mathrm{E}=\mathrm{EL}+\mathrm{FU} \ldots \ldots \ldots \ldots \ldots \ldots \ldots \ldots \ldots \ldots \ldots \ldots \ldots \ldots
$$

dengan : 
Total Permintaan Energi Final $\mathrm{E}=\sum \mathrm{E}_{\mathrm{i}}$

Total permintaan energi listrik $\mathrm{EL}=\sum \mathrm{EL}_{\mathrm{i}}$

Total permintaan bahan bakar $\mathrm{FU}=\sum \sum \mathrm{FU}_{\mathrm{ij}}$

$\mathrm{i}=$ Sektor (i industri)

$\mathrm{j}=$ Bahan bakar (minyak, batu bara, gas, dan lain-lain.)

Persamaan di atas memperlihatkan konsumsi energi final yang digunakan adalah hasil jumlah energi listrik dan bahan bakar yang dikonsumsi di semua sektor. Pemisahan energi dan bahan bakar berdasarkan asumsi tidak adanya subtitusi, antara satu energi dan sumber energi lainnya. Dalam analisis regresi yang diterapkan pada perkiraan permintaan energi, intensitas energi sebaiknya digunakan sebanyak mungkin. Persamaan permintaan energi dan permintaan bahan bakar dapat dijelaskan dengan anggapan bahwa permintaan sektoral adalah perkalian intensitas energi dan tingkat aktifitas ekonomi di setiap sektor. Secara umum intensitas-intensitas tersebut diestimasikan dengan analisis regresi dan indikator aktivitas ekonomi dipakai sebagai nilai exogenous pada model ekonomi makro.

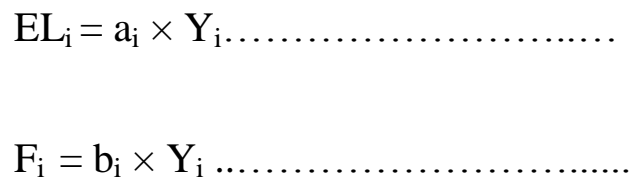

dengan :

$$
\begin{aligned}
& \mathrm{a}_{\mathrm{i}}=\mathrm{EL}_{\mathrm{i}} / \mathrm{Y}_{\mathrm{i}}\left(\mathrm{a}_{\mathrm{i}}=\text { intensitas energi pada tingkat aktivitas }\left(\mathrm{Y}_{\mathrm{i}}\right)\right) \\
& \mathrm{b}_{\mathrm{i}}=\mathrm{F}_{\mathrm{i}} / \mathrm{Y}_{\mathrm{i}}\left(\mathrm{bi}=\text { intensitas bahan bakar pada tingkat aktivitas }\left(\mathrm{Y}_{\mathrm{i}}\right)\right)
\end{aligned}
$$

Ketika menggunakan intensitas, permintaan energi dihitung berdasarkan persaman 2.4, sebagai berikut : 


$$
\mathrm{E}=\sum\left(\mathrm{a}_{\mathrm{i}} \times \mathrm{Y}_{\mathrm{i}}\right)+\sum\left(\mathrm{b}_{\mathrm{i}} \times \mathrm{Y}_{\mathrm{i}}\right)
$$

Jika digunakan sebagai fungsi sharing, pangsa dari sumber energi individu didistribusikan ke produk minyak, gas, batubara dan sebagainya. Jadi model mempertimbangkan subtitusi energi dan kompetisinya serta setiap pangsa dijelaskan terhadap harga relatif antara produk energi yang berbeda.

$$
F_{i j}(\text { bahan bakar } j)=F_{i} \times S_{i j} \ldots \ldots \ldots \ldots \ldots \ldots \ldots
$$

$S_{i j}=f\left(P e_{i j} / P e_{i}\right)$

dengan :

Sij : pangsa setiap sumber energi

Pe : harga energi

Permintaan energi primer dihitung menggunakan faktor konversi. Efisiensi konversi biasanya meningkat dengan adanya perbaikan teknologi khususnya peralatan baru. Tren waktu dan harga energi real akan menjadi variabel explanatori yang merepresentasikan perbaikan teknologi.

$$
\mathrm{PER}=\mathrm{EL} / \alpha+\mathrm{F}_{\mathrm{j}} / \beta_{\mathrm{j}}
$$

$$
\begin{aligned}
& \alpha=f\left(T, P_{e}\right) \\
& \beta=f\left(T, P_{e}\right)
\end{aligned}
$$

dengan :

PER : Permintaaan energi primer $\alpha$ dan $\beta \mathrm{j} \quad$ : Faktor konversi 
$\mathrm{T}$ : Tren waktu

Pada kajian ini metode yang dipakai adalah metode bottom-up dengan faktor intensitas menjadi dominan dalam setiap pembuatan modelnya. Meskipun demikian dalam pembuatan model dapat digunakan model hasil regresi sehingga hasilnya akan lebih baik.

\subsubsection{Model Peramalan/proyeksi}

Dari uraian di atas maka dapat dilakukan beberapa pendekatan pembangunan model peramalan energi (Winarno, 2005) yang dapat dibangun dari yang paling sederhana sampai yang sangat rumit. Secara umum model tersebut dapat dibedakan dalam lima pendekatan utama, yaitu pendekatan proses (reference energy system/RES), pendekatan trend, pendekatan elastisitas, pendekatan ekonometri dan pendekatan input/output. Berbagai alternatif proyeksi dapat dibuat dengan menggunakan satu atau beberapa teknik analisis yang tersedia. Pada kajian ini akan dibahas metode prakiraan dengan pendekatan ekonometrik untuk memperkirakan besarnya permintaan dan penyediaan energi nasional 35 tahun ke depan dengan menggunakan alat bantu berupa perangkat lunak komputer.

\subsubsection{Perangkat Lunak LEAP (Long-Range Energy Alternatives Planning)}

The Long-range Energy Alternatives Planning atau kemudian disingkat dengan LEAP adalah sebuah perangkat lunak yang sudah secara luas digunakan untuk analisis kebijakan energi dan penilaian terhadap mitigasi perubahan iklim yang dikembangkan di Stockhlom Environment Institute (SEI). Perangkat ini telah digunakan oleh ratusan organisasi di lebih dari 169 negara di dunia. Di antara 
pemakainya meliputi pemerintahan, akademisi, organisasi swasta, perusahaan konsultan dan banyak kepentingan energi lainnya. Perangkat ini telah digunakan dalam skala kota, negara hingga bangsa, regional bahkan secara global (Prasad, Bansal, \& Raturi, 2014).

Metodologi pemodelan dalam LEAP adalah akuntasi. Permintaan energi atau pemasokan energi dalam metode akuntasi ini dihitung dengan menjumlahkan pemakaian dan pemasokan energi masing-masing jenis kegiatan (Heaps, 2012). Perangkat lunak ini juga memiliki scenario manager atau pemilihan skenario yang sesuai dengan peraturan yang berlaku. Hasil dari pemilihan skenario dapat menunjukkan konsistensi perubahan sistem energi yang telah direncanakan sesuai dengan waktu ditentukan.

Metode bottom-up adalah metode yang digunakan dalam proses akuntasi untuk meramalkan/ forecasting kebutuhan energi secara nasional, regional, atau sesuai dengan level yang diinginkan (Suganthi \& Samuel, 2012). Dalam perencanaan energi dibutuhkan pemilihan perangkat lunak yang sesuai dengan tujuan kebutuhan energi. Pada Tabel 2.1 diberikan penjelasan mengenai perencanaan energi dan pemilihin perangkat lunak. 
Tabel 2.2 Perbandingan perangkat lunak sistem energi

\begin{tabular}{|c|c|c|c|c|c|}
\hline \multirow[t]{2}{*}{ Tool } & \multicolumn{3}{|c|}{ Energy-sectors considered } & \multicolumn{2}{|c|}{ Renewable-energy penet rations simulated } \\
\hline & Eectricity sector & Heat sector & Transport sector & $100 \%$ electricity simulated & $100 \%$ renewable energy-system \\
\hline \multicolumn{6}{|c|}{ Reports available detailing these renewable-energy penetrations } \\
\hline EnergyPLAN & Yes & Yes & Yes & Yes & Yes \\
\hline INFORSE & Yes & Yes & Yes & Yes & Yes \\
\hline Mesap HaNet & Yes & Yes & Yes & Yes & Yes \\
\hline H2RES & Yes & Yes & Partly & Yes & Yes \\
\hline SimREN & Yes & Yes & Partly & Yes & Yes \\
\hline energyPro & Yes & Partly & - & Yes & Partlya \\
\hline HOMER & Yes & Yes & - & Yes & Partlya \\
\hline TRNSYS16 & Yes & Yes & - & Yes & Partlya \\
\hline PERSEUS & Yes & Yes & Partly & Yes & - \\
\hline MESSAGE & Yes & Yes & Yes & - & - \\
\hline NEMS & Yes & Yes & Yes & - & - \\
\hline \multicolumn{6}{|c|}{ Reparts NOT available detailing these renewable-energy penetrations } \\
\hline LEAP & Yes & Yes & Yes & Yes & Yes \\
\hline Invert & Yes & Yes & Partly & Yes & Yes \\
\hline EMPS & Yes & - & - & Yes & Partlya \\
\hline ProdRisk & Yes & - & - & Yes & Partly ${ }^{a}$ \\
\hline RETScreen & Yes & Yes & - & Yes & Partly ${ }^{a}$ \\
\hline MinKCAM & Yes & Partly & Yes & Yes & - \\
\hline SIVAEL & Yes & Partly & - & Yes & - \\
\hline COMPOSE & Yes & Yes & Yes & - & - \\
\hline ENPEP-BALANCE & Yes & Yes & Yes & - & - \\
\hline IKARUS & Yes & Yes & Yes & - & - \\
\hline MARKAL/TIMES & Yes & Yes & Yes & - & - \\
\hline PRIMES & Yes & Yes & Yes & - & - \\
\hline E4cast & Yes & Yes & Partly & - & - \\
\hline STREAM & Yes & Yes & Partly & - & - \\
\hline EMINENT & Yes & Yes & - & - & - \\
\hline UniSyD3.0 & Yes & Partly & Yes & - & - \\
\hline WILMAR Planning Tool & Yes & Partly & Partly & - & - \\
\hline BALMORE & Yes & Partly & - & - & - \\
\hline GTMax & Yes & Partly & - & - & - \\
\hline RAMSES & Yes & Partly & - & - & - \\
\hline HYDROCEMS & Yes & - & - & - & - \\
\hline ORCED & Yes & - & Partly & - & - \\
\hline EMCAS & Yes & - & Partly & - & - \\
\hline WASP & Yes & - & - & - & - \\
\hline AEOLUS & Yes & - & - & - & - \\
\hline BCHP Screening Tool & - & - & - & - & - \\
\hline
\end{tabular}

Sumber : (Connolly, Lund, Mathiesen, \& Leahy, 2010)

Pada Tabel 3.1 diberikan perbandingan masing-masing fitur pada penggunaan sektor energi yaitu listrik, panas, dan transportasi. Pada software LEAP memiliki kekurangan yaitu tidak dapat menunjukkan penggunaan detail energi seperi penggunaan listrik per bulan, per hari, atau per jam. Sebaliknya, LEAP dari segi pemodelan dan simulasi dapat menunjukkan gambaran kebutuhan dan pemenuhan energi secara periodik dalam waktu yang tak terbatas (Connolly et al., 2010). 


\subsubsection{Pola Kebutuhan Energi}

Pertumbuhan penggunaan energi dipengaruhi oleh beberapa faktor, antara lain : pertumbuhan ekonomi dan pertambahan penduduk. Dalam situasi normal, pertumbuhan penggunaan energi dapat ditentukan berdasarkan konsep elastisitas. Elastisitas penggunaan energi dinyatakan sebagai persentase pertumbuhan energi (per kapita) dibandingkan dengan persentase pertumbuhan ekonomi (Sugiyono \& Boedoyo, 1999).

Secara umum, untuk jangka panjang keberhasilan pembangunan akan menyebabkan bergesernya penggerak ekonomi dari sektor pertanian ke sektor industri dan akhirnya beralih ke sektor jasa. Dalam kurun 30 tahun Indonesia sudah bergeser dari sektor pertanian ke sektor industri. Tetapi ternyata sektor industri di Indonesia masih sangat tergantung dari bahan baku import.

Untuk memudahkan pembahasan selanjutnya, sektor perekonomian dikelompokkan menjadi 6 buah sektor yaitu :

a. sektor pemerintah, termasuk di dalamnya fasiltas umum;

b. sektor rumah tangga;

c. sektor komersial;

d. sektor industri besar, yang termasuk di sini di antaranya industri baja, semen, pupuk, nikel, tembaga dan timah;

e. sektor industri sedang dan kecil, termasuk di dalamnya agroindustri/pertanian;

f. sektor transportasi. 
Dalam kondisi normal, pertumbuhan setiap sektor dapat diprediksi berdasarkan data historis. Dengan adanya krisis moneter dituntut adanya perubahan struktur ekonomi. Ini menyebabkan prediksi pertumbuhan tidak dilakukan melalui pola pertumbuhan konvensional yang berdasarkan data historis. Pada gambar 2.1 ditunjukkan kebutuhan energi Indonesia.

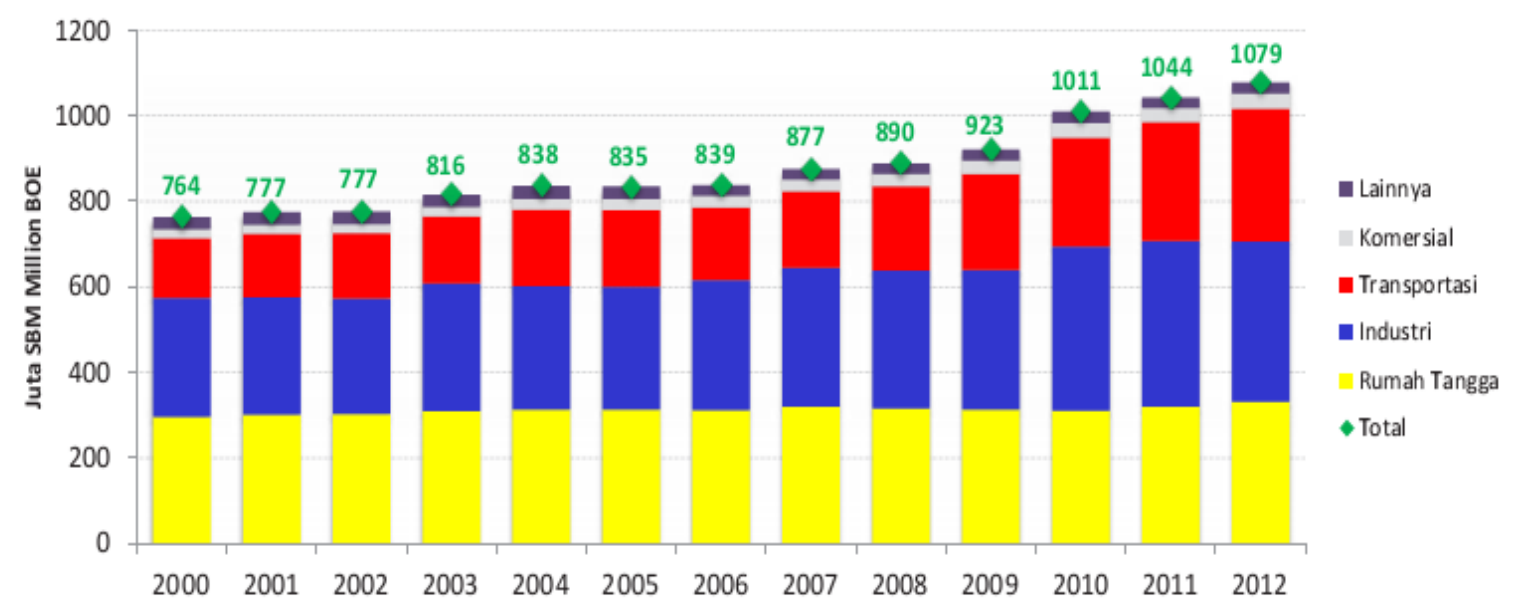

Gambar 2.1 Kebutuhan Energi Indonesia Per Sektor

Sumber: (Sugiyono, Anindhita, Boedoyo, \& Adiarso, 2014)

\subsubsection{Sektor Pemerintah}

Sektor ini tidak banyak mengalami pertumbuhan karena dana pemerintah yang terbatas. Pada saat krisis pertumbuhannya mendekati nol dan akan naik perlahan-lahan untuk jangka panjang. Dengan terbatasnya dana, fasilitas umum juga kurang mendapat perhatian.

\subsubsection{Sektor Rumah Tangga}

Rumah tangga yang berada di perkotaan berdasarkan sektor industri dan rumah tangga pedesaan yang berbasis pertanian. Sektor ini akan terus berkembang seiring pertumbuhan ekonomi. 


\subsubsection{Sektor Komersial}

Sektor ini merupakan sektor yang menggambarkan perdagangan atau perekonomian yang erat kaitannya dengan industri besar.

\subsubsection{Sektor Industri Besar dan Kecil}

Parameter yang mempengaruhi kelangsungan hidup suatu industri adalah bahan baku dan pemasaran hasil produk. Bila bahan baku berasal dari impor maka industri tersebut tidak akan kompetitif bila dibandingkan dengan industri yang menggunakan bahan baku lokal. Sedangkan untuk hasil produk, industri akan tetap tumbuh bila pemasarannya untuk konsumsi eksport, sedangkan industri yang pemasarannya untuk konsumsi dalam negeri kemungkinan pertumbuhannya mengalami penurunan. Sektor industri besar kebanyakan adalah industri yang bahan bakunya dari impor dan untuk konsumsi lokal,

Industri sedang/kecil kebanyakan menggunakan bahan baku lokal dan untuk konsumsi lokal. Beberapa industri sedang seperti agroindustri mempunyai keunggulan karena menggunakan komponen lokal dan untuk pasaran ekspor. Sektor industri sedang/kecil ini diharapkan masih akan tumbuh dan harga jual produk dalam US\$ akan lebih murah karena turunnya nilai Rupiah terhadap US\$. Hal ini akan membuat hasil produk lebih kompetitif di pasar internasional. Disamping itu komitmen pemerintah untuk lebih memberdayakan sektor industri sedang/kecil ini akan memungkinkan industri ini lebih banyak mengambil porsi dalam menyumbang PDB. 


\subsubsection{Sektor Transportasi}

Sarana transportasi sangat diperlukan dalam rangka memobilisasi barang maupun orang dari suatu tempat ke tempat lain. Sehubungan dengan konsumsi energi, sektor transportasi yang dimaksud mencakup sarana transportasi yang digerakkan oleh mesin atau kendaraan bermotor. Terdapat tiga jenis energi yang dikonsumsi oleh sektor transportasi yaitu BBM, gas dan listrik.

\subsubsection{Pola Penyediaan Energi}

Penyediaan energi (Energy Supply) untuk masa depan merupakan permasalahan yang senantiasa menjadi perhatian semua bangsa karena kesejahteraan manusia dalam kehidupan modern sangat terkait dengan jumlah dan mutu energi yang dimanfaatkan. Bagi Indonesia yang merupakan salah satu negara sedang berkembang, penyediaan energi merupakan faktor yang sangat penting dalam mendorong pembangunan. Seiring dengan meningkatnya pembangunan diberbagai sektor, pertumbuhan ekonomi dan pertumbuhan penduduk, kebutuhan akan energi akan terus meningkat

Dalam memenuhi kebutuhan energi, penyedian energi nasional dipasok dari produksi domestik dan impor. Pasokan energi dari produksi domestik sangat tergantung teknologi dan infrastruktur energi. Infrastruktur energi terdiri dari infrastruktur konversi energi (berupa kilang minyak, gas dan pembangkit listrik), infrastruktur transmisi dan distribusi energi (pipa minyak, pipa gas, jaringan transmisi dan distribusi listrik), dan infrastruktur fisik (pelabuhan, jalan darat, angkutan sungai dan kereta api). 
Pada saat ini, Indonesia memiliki keterbatasan dalam hal tersebut. Teknologi ekplorasi dan infrastruktur energi membutuhkan modal yang besar dan dalam jangka waktu yang panjang. Untuk itu diperlukan kebijakan pemerintah dalam meningkatkan investasi di bidang energi. Dengan keterbatasan tersebut, untuk memenuhi kebutuhan energi domestik dapat dilakukan impor minyak dari negara lain. Impor minyak sangat tergantung dengan berapa besar kebutuhan akan energi, harga minyak dunia dan nilai tukar Rupiah terhadap Dolar AS (Elinur, Priyarsono, Tambunan, \& Firdaus, 2010). Pada gambar 2.2 ditunjukkan pola penyediaan energi.

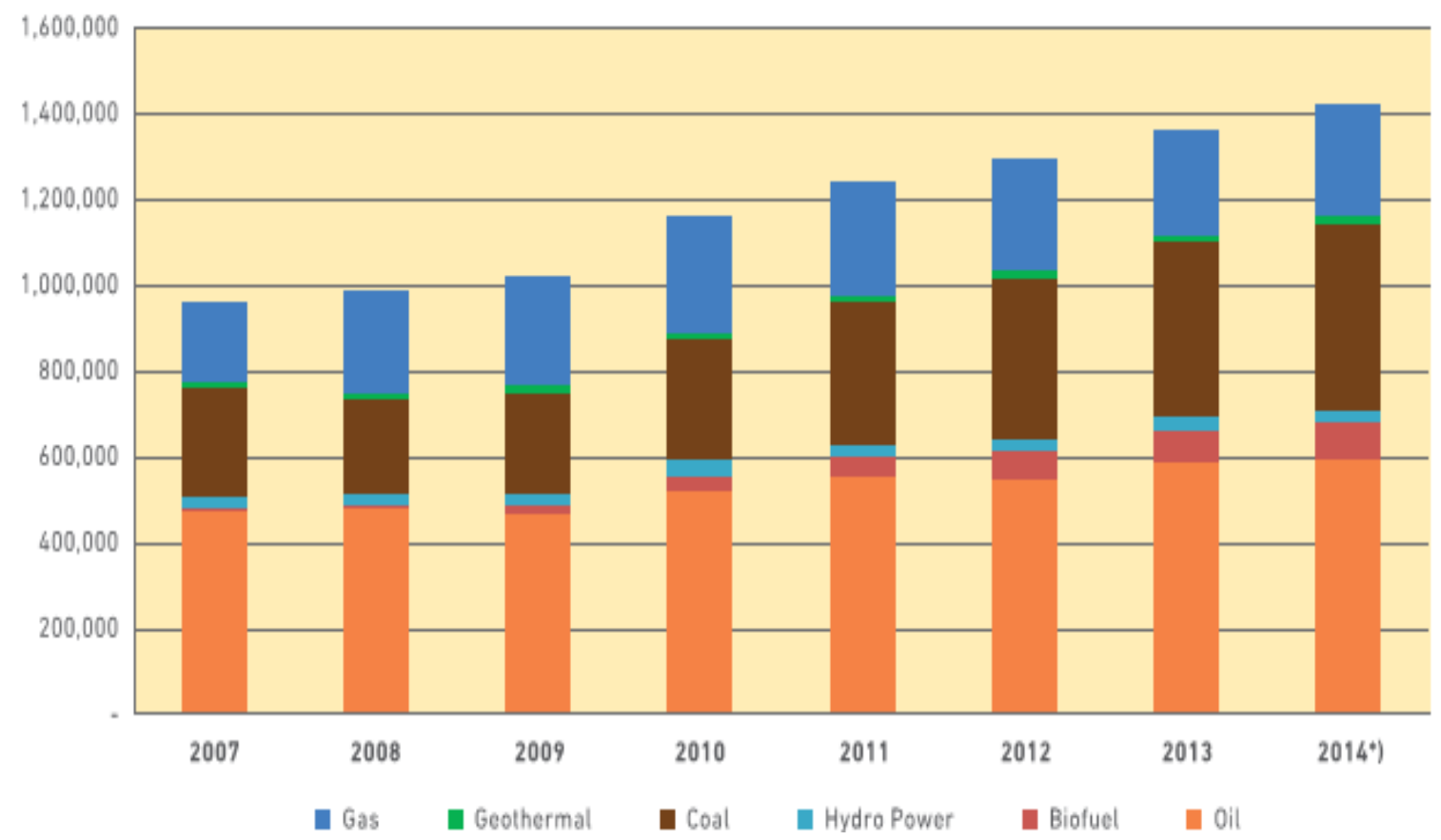

Gambar 2.2 Penyediaan Energi Indonesia

Sumber : (The National Energy Council, 2015) 


\subsubsection{Batu Bara}

Indonesia merupakan salah satu negara produsen batubara terbesar di dunia. Saat ini sebagian besar dari produksi batubara Indonesia adalah untuk diekspor, sedangkan sisanya untuk memenuhi kebutuhan energi dalam negeri. Namun di masa datang, semakin tingginya kebutuhan batubara dalam negeri diperkirakan akan menyebabkan semakin menurunnya pangsa ekspor batubara. Indonesia juga mengimpor batubara dalam bentuk kokas untuk industri metalurgi dalam jumlah yang kecil. Batubara memiliki peranan yang penting dalan pemenuhan kebutuhan energi dan jaminan ketersediaan energi bagi industri, khususnya untuk pembangkit listrik.

\subsubsection{Minyak Mentah}

Minyak mentah (Crude Oil) sebagai bahan baku untuk menghasilkan bahan bakar, seperti bensin (premium), solar, minyak diesel, minyak tanah dan pelumas. Dengan demikian minyak mentah memiliki peranan dalam mencukupi kebutuhan energi. Minyak mentah bersumber dari cadangan alam yang tidak dapat diperbaharui, sehingga cadangannya makin menipis sejalan dengan tuntutan kebutuhan energi yang semakin meningkat.

Peningkatan ekonomi akan mendorong pemanfaatan BBM terutama pada sektor transportasi sebagai pengguna utama BBM. Hal ini perlu didukung oleh adanya peningkatan penyediaan minyak mentah yang memadai. Sejak tahun 2004 produksi minyak mentah dalam negeri tidak mencukupi untuk memenuhi kebutuhannya, sehingga Indonesia menjadi importir minyak mentah. Hal ini terjadi karena belum ditemukannya cadangan minyak dalam jumlah besar 
berakibat pada menurunnya jumlah cadangan minyak mentah (Sugiyono et al., 2014).

\subsubsection{Gas Bumi}

Gas bumi adalah hasil proses alami berupa hidrokarbon yang dalam tekanan dan temperatur atmosfer berupa fase gas yang diperoleh dari proses. Total cadangan gas bumi Indonesia pada 2011 mencapai sekitar 153 TSCF yang terdiri dari cadangan terbukti sebesar 105 TSCF dan cadangan potensial lebih dari 48 TSCF. Total cadangan gas tersebut pada 2012 cenderung menurun mencapai 151 TSCF yang terdiri atas 103 TSCF cadangan terbukti dan 47 TSCF cadangan potensial.

Dengan Tingkat produksi gas baik gas ikutan (associated) maupun gas bukan ikutan (non associated) mencapai 3,26 TCF pada 2011 dan 3,17 TCF pada 2012, rasio cadangan produksi gas mencapai secara berurutan meningkat 32 tahun pada 2011 dan 33 tahun pada 2012Sumber daya gas tersebut umumnya berada di luar Jawa, terutama di Sumatera termasuk Natuna yang mencapai hampir 56 persen. Cadangan gas di luar Jawa lainnya tersebar di Papua, Kalimantan, Maluku, dan Sulawesi yang masing-masing memiliki cadangan gas secara berurutan $16 \%, 11 \%, 10 \%$, dan hampir $2 \%$. Sementara itu di Jawa, cadangan gasnya hanya sekitar delapan persen dari total cadangan gas Indonesia.

\subsubsection{Energi Terbarukan}

Energi terbarukan didefinisikan sebagai energi yang dapat diperoleh ulang (terbarukan) seperti sinar matahari dan angin. Sumber energi terbarukan adalah 
sumber energi ramah lingkungan yang tidak mencemari lingkungan dan tidak memberikan kontribusi terhadap perubahan iklim dan pemanasan global seperti pada sumber-sumber tradisional lain

Indonesia memiliki potensi energi terbarukan seperti tenaga air, panas bumi, angin, surya, samudera, maupun biomasa jumlahnya cukup memadai namun tersebar. Berdasarkan data ESDM (2013), cadangan panas bumi Indonesia sebesar 16.484 MW dari potensi sekitar 28.617 MW. Kapasitas terpasang pembangkit panasbumi (hingga September 2013) sebesar 1.242 MW. Sementara itu, potensi biomasa untuk kelistrikan mencapai 49,8 GWe dengan kapasitas terpasang pembangkit yang terhubung ke grid sebesar 445 MWe. Potensi tenaga surya di Indonesia cukup tinggi dengan intensitas sebesar 4,8 $\mathrm{kWh} / \mathrm{m} 2 /$ day dengan pemanfaatan baru sebesar 12,1 MWe. Kapasitas terpasang pembangkit tenaga angin baru sekitar 1,1 MWe dari potensi 9.290 MWe (Sugiyono et al., 2014)

\subsection{Hipotesis}

Permintaan dan penyediaan energi provinsi Sulawesi Selatan pada tahun 2025 dan 2050 menggunakan skenario sistem energi bersih belum ada. Bauran energi yang ada di Sulawesi Selatan didominasi oleh fosil dan proyeksi bauran energi untuk tahun 2025 dan 2050 per sumber energi belum ada. Besaran sharing energi terbarukan untuk memenuhi permintaan energi di Sulawesi Selatan membutuhkan proyeksi. Tingkat ketahanan energi di Sulawesi Selatan belum ditentukan. 


\section{BAB III}

\section{METODE PENELITIAN}

\subsection{Data penelitian}

Dalam penelitian, ini bahan yang diperlukan adalah data ekonomi, data kependudukan, data pemakaian energi, data infrastruktur energi terbarukan dan data potensi energi terbarukan. Penelitian ini menggunakan skenario sistem energi bersih atau clean energy. Sistem energi bersih merupakan usaha untuk meningkatkan penggunaan energi terbarukan dan penggunaan teknologi bersih untuk mengurangi efek dari aktivitas energi fosil yang ada pada suatu kawasan. Teknologi bersih yang dapat diterapkan seperti clean coal technology untuk menangkap emisi dan polusi yang ada pada pembangkit batu bara.

Berikut data yang diperlukan sebagai input analisis permintaan energi di provinsi Sulawesi Selatan :

- Data Ekonomi

- Pendapatan Regional Bruto Daerah (PDRB)

- $\quad$ PDRB per Kapita

- Pertumbuhan PDRB

- Data Kependudukan

- Jumlah penduduk

- Pertumbuhan penduduk

- Data Pemakaian Energi

- Jenis dan jumlah energi yang digunakan

- Data Potensi Energi Terbarukan 
- Jenis dan jumlah potensi yang mungkin dibangkitkan

- Data Infrastruktur Energi Terbarukan

- Infrastruktur energi terbarukan yang telah dibangun di provinsi Sulawesi Selatan

- Roadmap Pengembangan energi terbarukan di provinsi Sulawesi Selatan.

- Data Skenario Sistem Energi Bersih

- Rencana Pembangunan Jangka Menengah Daerah (RPJMD) Sulawesi Selatan

- Rencana Usaha Pembangunan Tenaga Listrik (RUPTL) PT. PLN ( Persero)

- $\quad$ Rencana Induk Perkeretaapian Nasional (RIPNAS)

- Rencana Umum Ketenagalistrikan Daerah (RUED) Sulawesi Selatan

Seluruh data tersebut adalah data sekunder yang diperoleh dari beberapa dinas dan instansi terkait di provinsi Sulawesi Selatan.

\subsection{Alat Penelitian}

Alat yang digunakan dalam penelitian ini adalah :

- Laptop

- Perangkat lunak Microsoft Excel

- Perangkat lunak LEAP ( Long-range Energi Alternative Planning System) ditunjukkan pada gambar 3.1 


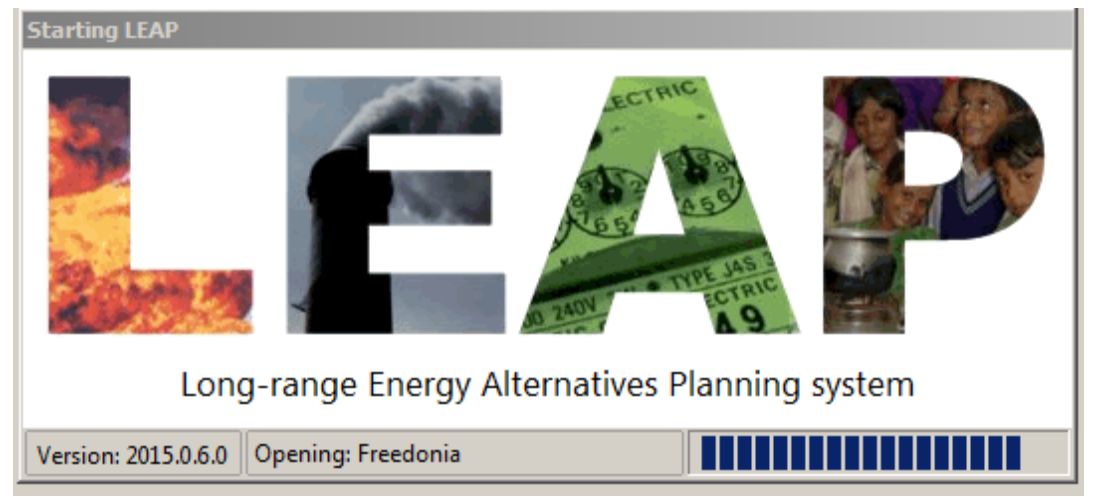

Gambar 3.1 LEAP Versi 2015.0.8.0

\subsection{Tata Laksana Penelitian}

Penelitian ini dilakukan dengan beberapa tahapan sebagai berikut :

a. Studi literatur

Studi literatur dilakukan dengan mempelajari beberapa literatur yang memiliki keterkaitan dengan penelitian ini, baik berupa teori dasar, outlook, kajian energi, jurnal, slide presentasi. Melakukan identifikasi masalah mengenai penelitian yang dijadikan usulan, menggunakan saransara peneliti terdahulu untuk dijadikan sebagai peluang masalah yang dibahas pada penelitian ini.

b. Pengumpulan Data

Data dikumpulkan dari Badan Pusat Statistik (BPS), Dinas Pertambangan dan Energi Sulawesi Selatan, PT. PLN, PT. PERTAMINA, dan lain-lain. Data yang digunakan dalam penelitian ini adalah data sekunder.

c. Pengolahan data

1. Pengelompokan konsumsi energi per sektor 
Pengelompokan dan pengolahan data awal dari berbagai sektor dilakukan dengan menggunakan software Excel 2007. Data-data tersebut dimasukkan ke dalam aplikasi LEAP untuk diolah dan disimulasikan dalam perhitungan.

2. Perhitungan proyeksi konsumsi energi

Tahap ini merupakan penyusunan skenario. Skenario yang digunakan dalam penelitian ini adalah BAU ( Business as Usual) yang merupakan skenario proyeksi didasarkan pada anggapan bahwa pertumbuhan konsumsi energi akan berjalan sebagaimana biasanya seperti waktu sebelumnya dan tidak ada kebijakan di berbagai sektor. BAU dapat dilakukan dengan memilih Refference (REF) pada kotak scenario. Setelah itu muncul tampilan dimana harus memasukkan data expression. Setelah mengetahui skenario BAU, dilakukan simulasi berbagai skenario penghematan dari berbagai sektor.

3. Pemodelan dan perbandingan berbagai skenario Pemodelan dan perbandingan digunakan untuk menentukan solusi terbaik dari perhitungan konsumsi energi.

d. Analisis keseimbangan energi

Analisis keseimbangan energi dilakukan dengan menguraikan sisi permintaan dan sisi penyediaan. Neraca energi biasa digunakan untuk mempermudah mengidentifikasi antara permintaan dan penyediaan. Keseluruhan alur penelitian ditunjukkan pada Gambar 3.2. 


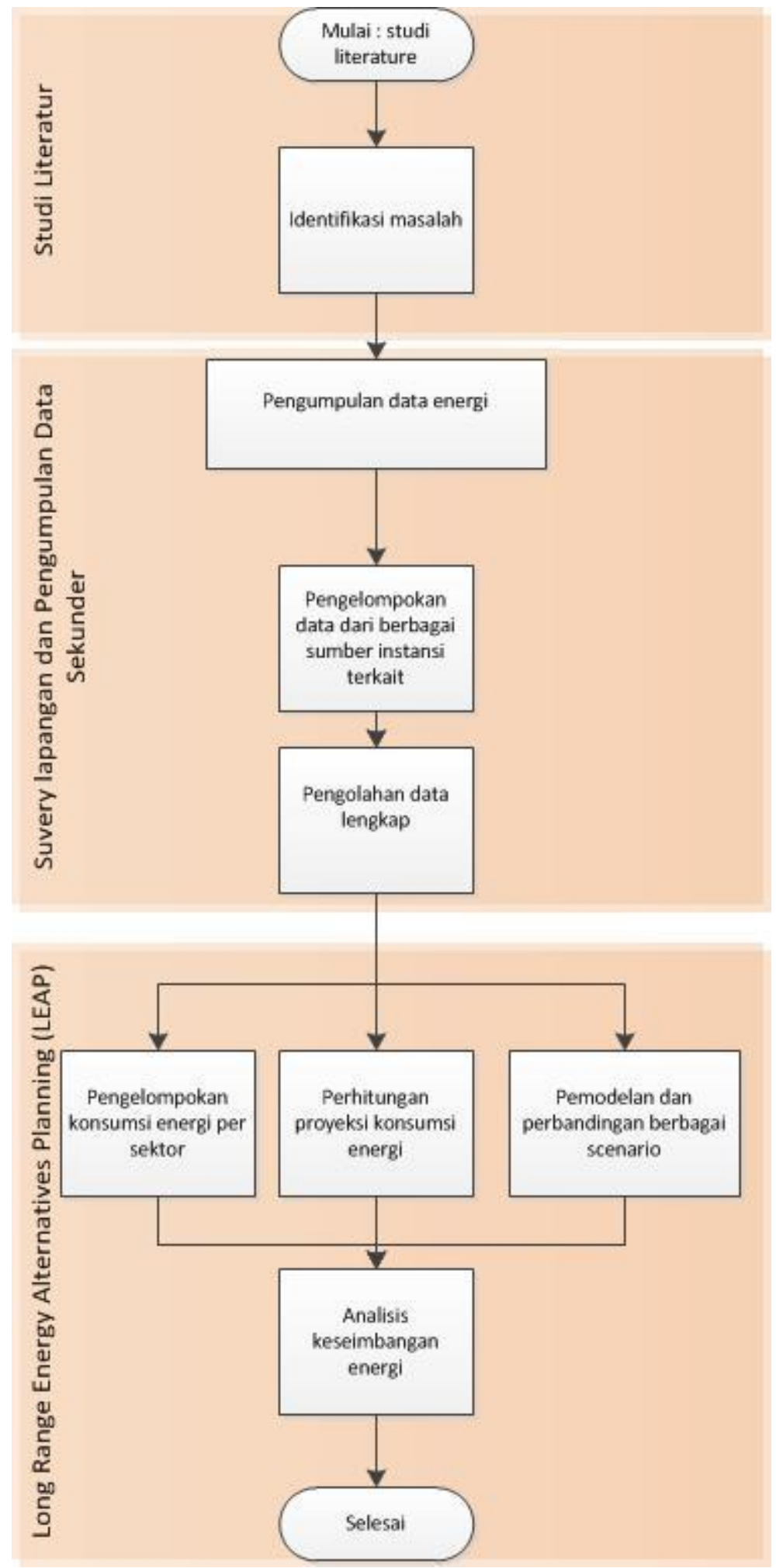

Gambar 3.2 Metode dan Alur Penelitian 


\section{BAB IV}

\section{HASIL PENELITIAN DAN PEMBAHASAN}

\subsection{Kondisi Sosial Ekonomi}

\subsubsection{Geografis}

Provinsi Sulawesi Selatan yang beribukota di Makassar terletak antara $0^{\circ} 12^{\prime}-8^{\circ}$ Lintang Selatan dan $116^{\circ} 48^{\prime} \quad 122^{\circ} 36^{\prime}$ Bujur Timur, yang berbatasan dengan Provinsi Sulawesi Barat di sebelah Utara dan Teluk Bone serta Provinsi Sulawesi Tenggara di sebelah Timur. Batas sebelah Barat dan Timur masing masing adalah Selat Makassar dan Laut Flores. Pada gambar 4.1 ditunjukkan bentuk geografis Sulawesi Selatan.

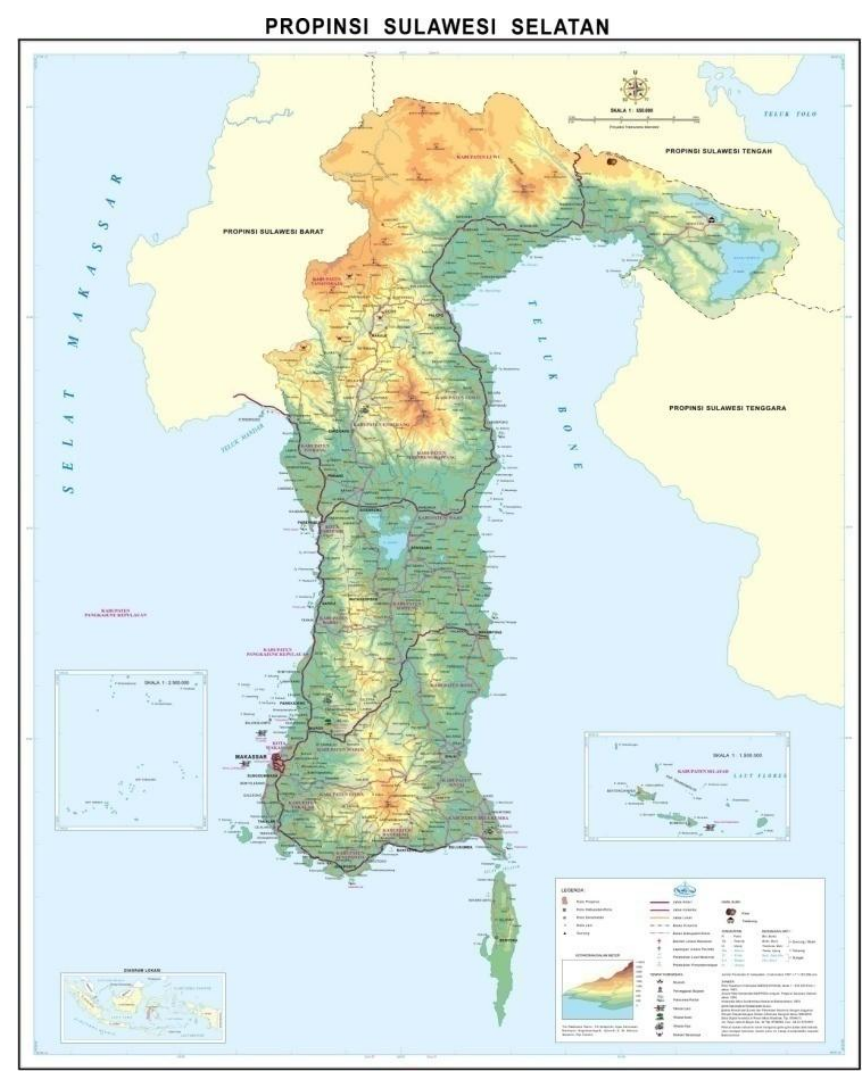

Gambar 4.1 Peta Provinsi Sulawesi Selatan 
Jumlah sungai yang mengaliri wilayah Sulawesi Selatan tercatat sekitar 67 aliran sungai, dengan jumlah aliran terbesar di Kabupaten Luwu, yakni 25 aliran sungai. Sungai terpanjang tercatat ada satu sungai yakni Sungai Saddang yang mengalir meliputi Kabupaten Tator, Enrekang dan, Pinrang. Panjang sungai tersebut masing-masing $150 \mathrm{~km}$.

Suhu udara Sulawesi Selatan pada tahun 2013 berada pada kisaran 23,4$32^{\circ} \mathrm{C}$ dengan kelembaban udara $71-93{ }^{\circ} \mathrm{C}$. Sedangkan kecepatan angin berkisar 4 knots dengan tekanan udara 1010,7-1011,5 mb. Keadaan cuaca atau iklim ini membuat Sulawesi Selatan relatif lebih hangat.

\subsubsection{Populasi penduduk}

Jumlah penduduk Sulawesi Selatan pada tahun 2013 adalah sekitar 8,3 juta jiwa, dimana setiap 95 laki-laki terdapat 100 perempuan. Semakin meningkatnya pertumbuhan ekonomi maka makin berkembang pula fasilitas publik. Hal ini berdampak pada semakin padatnya jumlah penduduk terutama di daerah perkotaan. Kini kepadatan penduduk Sulawesi Selatan telah mencapai angka 181 jiwa per kilometer persegi.

Seperti daerah lain pada umumnya, distribusi penduduk di Sulawesi Selatan memusat pada daerah perkotaan. Tercatat mayoritas penduduk Sulawesi Selatan menjadikan kota Makassar sebagai daerah tujuan untuk tempat tinggal baik untuk tujuan pekerjaan maupun untuk alasan lainnya. Makassar pun kini dipadati 17 persen penduduk Sulawesi Selatan. Pada lampiran 11 ditunjukkan jumlah penduduk dan pertumbuhan penduduk. 


\subsubsection{Produk Domestik Regional Bruto}

Produk Domestik Regional Bruto (PDRB) atau Gross Regional Domestic Product (GRDP) merupakan salah satu pencerminan kemajuan ekonomi suatu daerah, yang didefinisikan sebagai keseluruhan nilai tambah barang dan jasa yang dihasilkan dalam waktu satu tahun di wilayah tersebut.

Produk domestik regional bruto (PDRB) atas dasar harga berlaku menunjukkan kemampuan sumber daya ekonomi yang dihasilkan oleh suatu daerah. Nilai PDRB yang besar menunjukkan kemampuan sumber daya ekonomi yang besar. Sedangkan, PDRB atas dasar harga konstan dapat menunjukkan laju pertumbuhan ekonomi secara keseluruhan atau setiap sektor dari tahun ke tahun.

Produk domestik regional bruto Sulawesi Selatan atas dasar harga berlaku pada tahun 2013 sekitar 184.783,06 milyar rupiah. Sektor pertanian mempunyai nilai tambah paling besar dibandingkan sektor lain yaitu mencapai 44.162,54 milyar rupiah. Selanjutnya disusul oleh sektor perdagangan, hotel, restoran terbesar kedua dengan nilai tambah mencapai 33.031,58 milyar rupiah. Sektor industri pengolahan Sulawesi Selatan yang diharapkan mampu menunjang sektor pertanian dengan berorientasi pada agro industri ternyata nilai tambahnya terbesar keempat, yaitu mencapai 22.559,13 milyar rupiah. Pada lampiran 11 ditunjukkan PDRB atas harga berlaku, Pertumbuhan PDRB, dan PDRB per Kapita. 


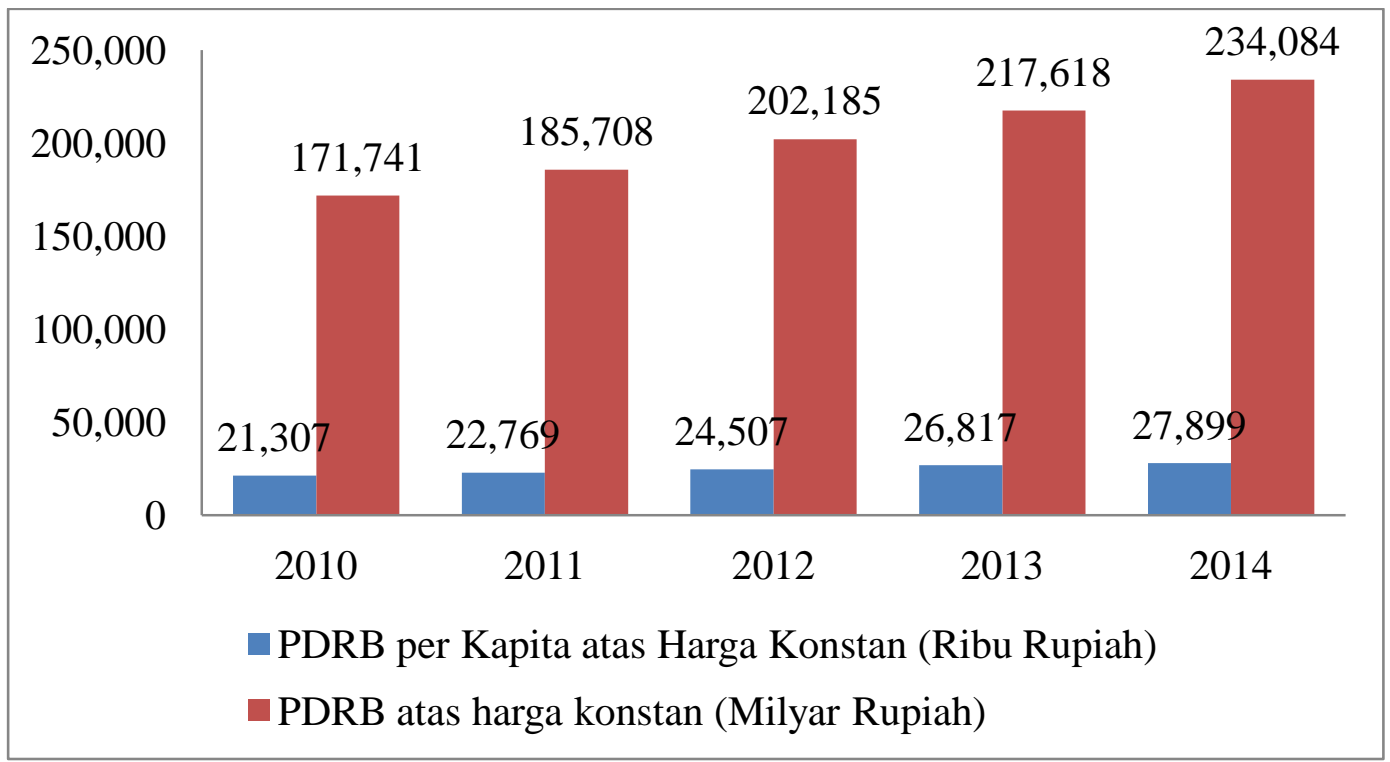

Gambar 4.2 Perbandingan PDRB per Kapita dan PDRB atas harga konstasn

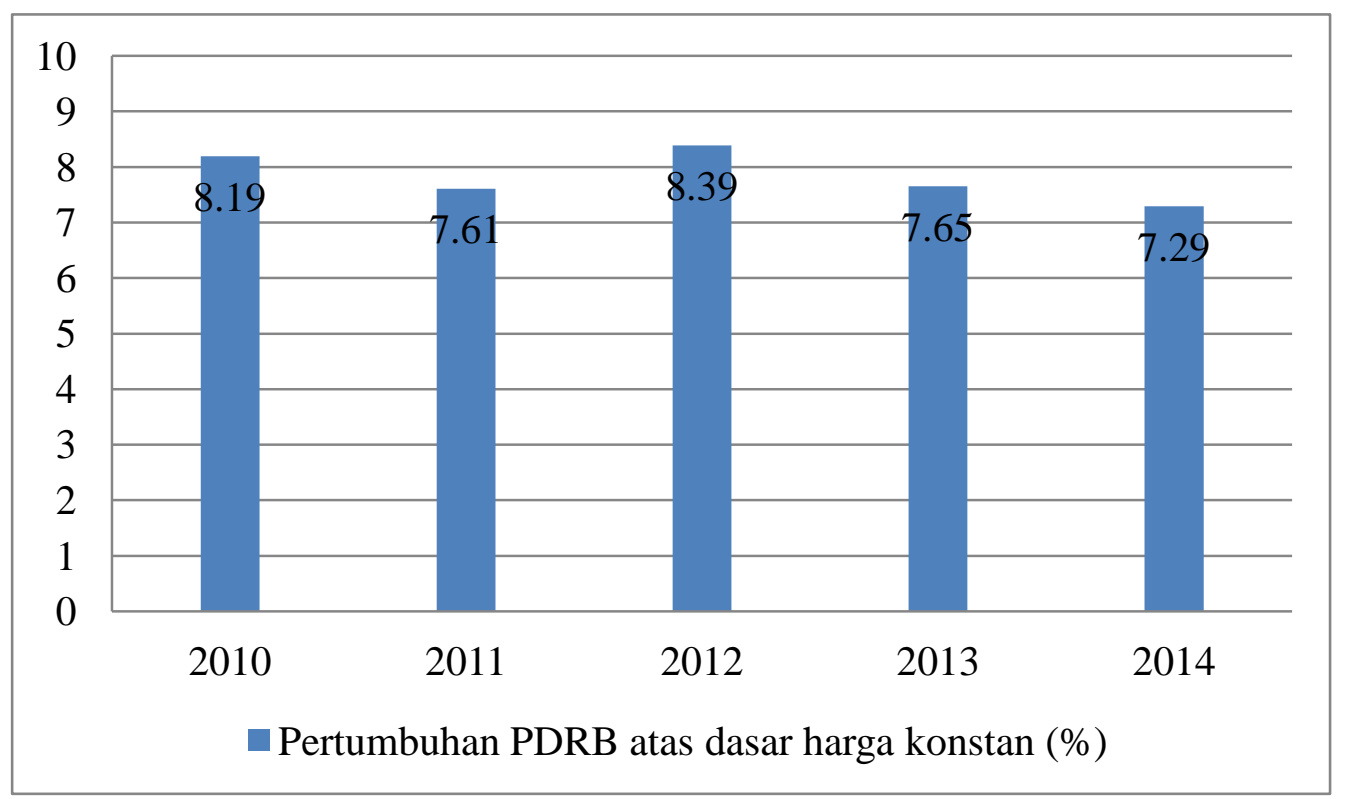

Gambar 4.3 Pertumbuhan PDRB atas dasar harga konstan 


\subsection{Kondisi Energi Sulawesi Selatan}

\subsubsection{Minyak dan Gas Bumi}

Cadangan minyak bumi dan gas alam di Sulawesi Selatan belum banyak ditemukan. Cadangan gas alam yang kini sedang diproduksi adalah di Sengkang adalah jumlah cadangan sebesar 603,70 BSCF yang setara 172,59 MW (Tim Kajian Pengembangan Energi \& ESDM, 2003). Pada lampiran 12 ditunjukkan konsumsi energi jenis bahan bakar minyak (BBM), sedangkan untuk bahan bakar gas terdapat pada lampiran 1 .

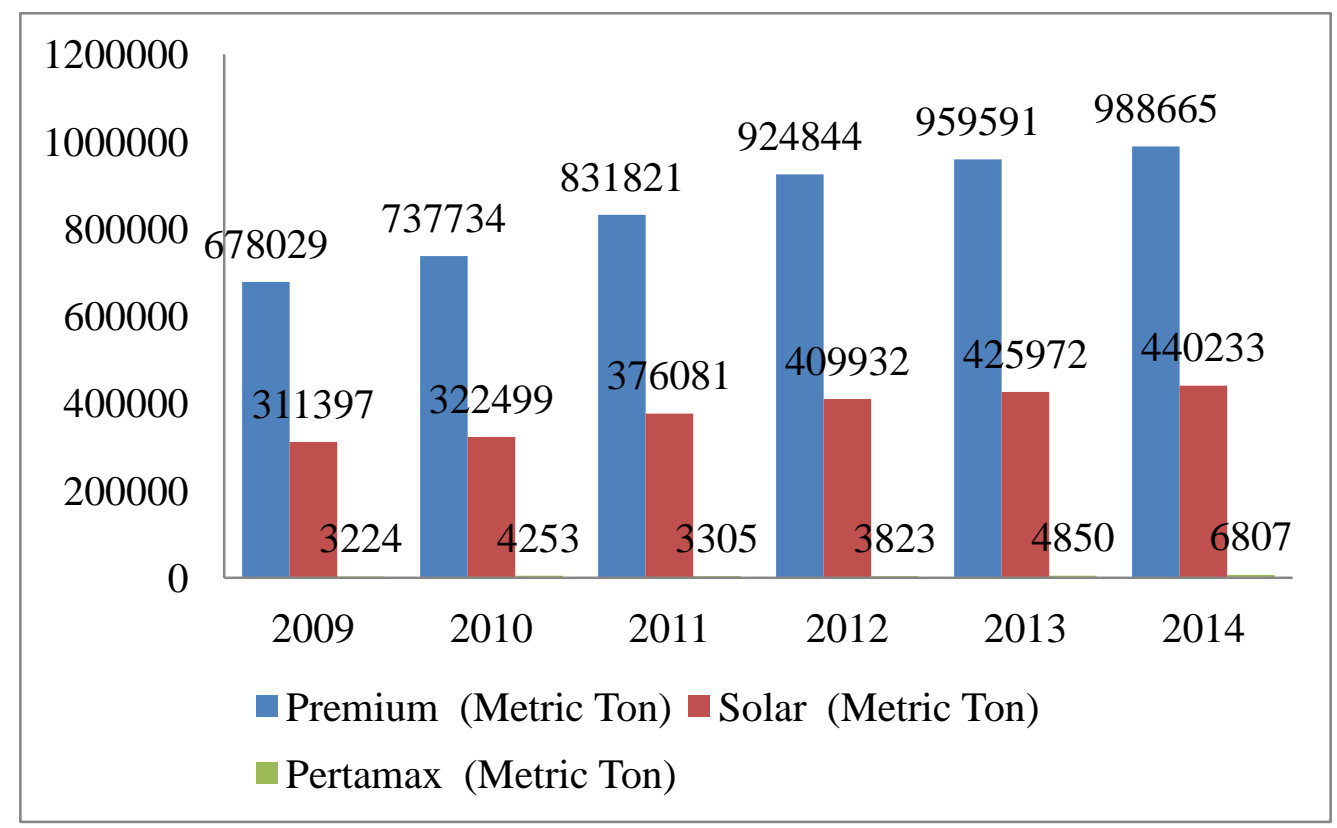

Gambar 4.4 Konsumsi Energi jenis BBM

\subsubsection{Batu Bara}

Potensi batubara di Sulawesi Selatan tersebar di berbagai kabupaten. Berdasarkan data sementara yang diperoleh dari Dinas Pertambangan dan Energi Sulawesi Selatan bahwa jumlah cadangan batubara di Sulawesi Selatan adalah 
37,3 juta ton $^{3}$ setara dengan 138.343.036 SBM (Tim Kajian Pengembangan Energi \& ESDM, 2003).

\subsubsection{Energi Baru Terbarukan}

\subsubsection{Air/Hidro}

Provinsi Sulawesi Selatan mempunyai banyak sumber energi primer dalam bentuk energi terbarukan terutama berupa tenaga air yang dapat dikembangkan menjadi PLTA. Potensi tenaga air yang dapat dikembangkan menjadi PLTA sekitar 1.836 MW dan yang dapat kembangkan menjadi PLTM sekitar 160 MW. Pada lampiran 12 dan 13 ditunjukkan mengenai PLTA dan PLTM yang sudah ada / existing hingga saat ini.

\subsubsection{Panas Bumi / Geothermal}

Sulawesi Selatan mempunyai potensi panas bumi (geothermal) yang dapat dikembangkan dan dimanfaatkan sebagai sumber tenaga pembangkit listrik tenaga panas bumi. Potensi yang ditemukan adalah sebesar 337 MW. Dinas Energi dan Sumber Daya Mineral (ESDM) Sulawesi selatan telah melakukan survey mengenai potensi tersebut. Pada gambar 4.5 ditunjukkan letak potensi panas bumi di Sulawesi selatan. 


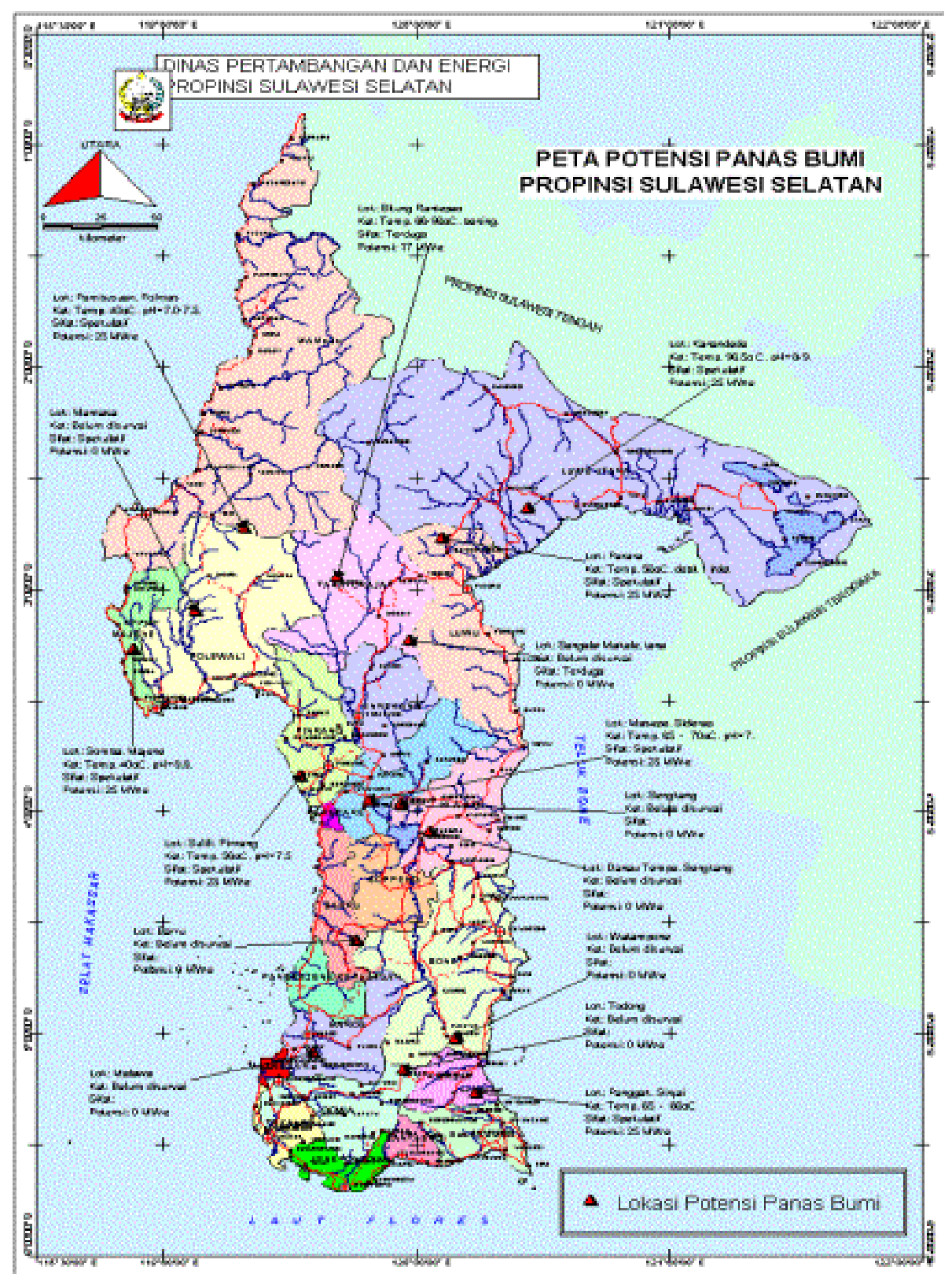

Gambar 4.5 Peta Potensi Panas Bumi Sulawesi Selatan

\subsubsection{Angin}

Potensi angin di Provinsi Sulawesi Selatan sangat besar. Secara umum energi angin relatif kecil. Kecepatan angin pada umumnya berkisar $6-7$ m/detik, maka perlu pemilihan lokasi yang berada di sekitar pinggir pantai. Pada gambar 4.6 ditunjukkan peta potensi angin Sulawesi selatan 


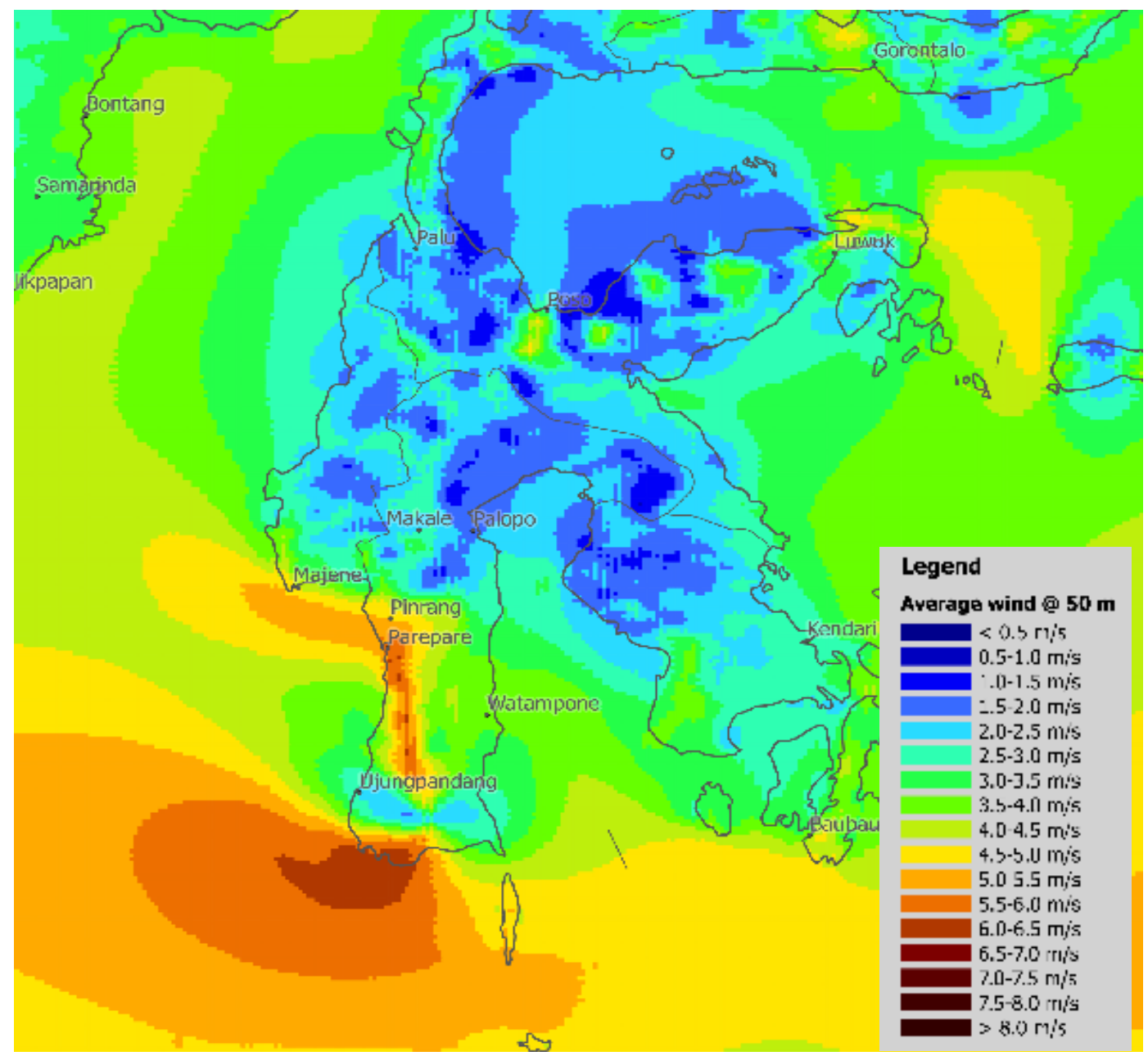

Gambar 4.6 Peta Potensi Angin Sulawesi Selatan

Sumber: ESP Denmark,2014

Pemerintah Sulawesi selatan telah melakukan program pembangunan Pembangkit Listrik Tenaga Bayu (PLTB) yaitu pada kabupaten Sidrap sebesar 100 MW dan Jeneponto sebesar 162.5 MW.

\subsubsection{Surya}

Potensi energi surya atau matahari yang telah dimanfaatkan untuk penerangan pada daerah pedesaan di Sulawesi Selatan yang belum terjangkau PLN adalah 14.799 unit dengan kapasitas $10 \mathrm{Wp}$ dan $50 \mathrm{Wp}$. Pembangkit listrik 
tenaga surya terpusat telah dibangun 5 unit yaitu Bantaeng, Selayar, Luwu, Sinjai dan Pangkep. Pada lampiran 14 ditunjukkan Pembangkit Listrik Tenaga Surya (PLTS) yang telah dibangun oleh pemerintah Sulawesi selatan dengan rincian kabupaten.

Potensi energi matahari yang dapat diakumuliasikan di Sulawesi Selatan menurut (Suyuti, 2011) adalah sebesar 593 MWh dari lima kota madya dan kabupaten yaitu Makassar, Palopo, Bone, Rantepao, dan Pare-pare.

\subsubsection{Biodiesel}

Potensi bioenergi Sulawesi Selatan yang berasal dari sumber nabati dan hewan adalah biodiesel, bioetanol, biogas, biobriket, dan biomassa. Biodiesel hingga saat ini merupakan sumber energi yang telah ada sejak tahun 2007 dengan potensi yang ada mencapai 601.992 Ha. Pada lampiran 15 ditunjukkan potensi biodiesel di Sulawesi Selatan.

Saat ini sedang dikembangkan oleh pemerintah Sulawesi selatan rumput laut sebagai sumber bahan biodiesel. Sulawesi selatan saat ini memiliki industri rumput laut yang cukup besar dengan tujuan ekspor ke luar negri. Dengan menggunakan potensi rumput laut yang melimpah karena Sulawesi selatan memmiliki garis pantai yang panjang dan dapat memanfaatkan potensi rumput laut untuk mengatasi krisis energi di Indonesia dibandingkan mengekspor untuk sumber pangan atau pun obat-obatan di luar negri. 


\subsubsection{Bioetanol}

Bioetanol adalah etanol yg dihasilkan dari biomassa yangg mengandung komponen pati dan selulosa, seperti singkong dan tetes tebu. Etanol dlm dunia industri digunakan sebagai campuran untuk minuman keras, bahan baku farmasi dan kosmetika. Etanol yang dapat difungsikan sebagai bahan bakar adalah yang berkadar alkohol di atas $99.5 \%$, dan dipakai sebagai subsitusi bensin (premium). Pada tahun 2008 ESDM Sulawesi Selatan mencatat potensi Bioetanol yang ditunjukkan pada lampiran 15. Dari data tabel pada lampiran 15 potensi untuk bioetanol sendiri mencapai 40.700 Ha. Bioetanol saat ini yang telah dikembangkan yaitu tanaman ubi kayu.

\subsubsection{Biogas}

Potensi biogas yang berasal dari kotoran hewan ternak terutama dari kotoran sapi yang mencapai 1.190.708 ekor pada tahun 2007. Pemerintah Sulawesi Selatan telah membangun insatalasi biogas 200 unit di enam kabupaten di Sulawesi Selatan yaitu Bulukumba, Sinjai, Maros, Wajo, Pangkep, dan Sidrap. Pada lampiran 16 ditunjukkan biogester berdasarkan jumlah hewan ternak. 13 juta ternak sapi perah dan daging, serta 15,6 juta ternak setara dengan 1 juta unit digester biogas rumah tangga atau 2.3 juta Setara Barel Minyak (SBM).

\subsubsection{Biomassa}

Energi biomassa dari bahan baku sekam padi merupakan potensi yang besar di provinsi Sulawesi Selatan dengan jumlah energi 3.274.453.734.384 Kcal (Nurmawati, 2009). Pada lampiran 17 ditunjukkan mengenai Potensi dari setiap jenis tanaman yang dapat diubah menjadi biomassa. 
Poteni energi baru dan terbarukan di Sulawesi Selatan cukup besar dan beragam untuk dikembangan dan digunakan sebagai pemenuhan energi nasional yang bersumber dari energi alternatif.

\subsubsection{Ketenagalistrikan}

Penjualan energi listrik di Sulawesi Selatan dalam periode tahun 2006 sampai dengan 2010 menunjukkan pertumbuhan yang cukup besar yaitu sebesar 36,4\% dimana pada tahun 2006 pemakaian energy listrik sebanyak $2141.2 \mathrm{GWh}$ dan pada tahun 2010 sebesar 2,921.1 GWh.

Kelompok pelanggan yang menggunakan energi listrik yang tersebesar adalah Rumah Tangga, dimana dalam periode 5 tahun rata-rata menggunakan enegri listrik sebesar 1164,9 GWh tiap tahun. Kelompok Rumah tanga ini pada tahun 2006 mengkonsumsi energy listrik sebesar 982,6 GWh dan pada tahun 2010 sebesar 1435,3 GWh sehingga pertumbuhan pemakakaian enegi dalam periode tahun tersebut adalah sebesar 46\% (Rencana Umum Ketenagalistrikan Daerah (RUKD) Propinsi Sulawesi Selatan, 2003). Pada lampiran 17 ditunjukkan data terbaru pemakaian energi jenis listrik pada tahun 2012-2014.

Sistem kelistrikan Provinsi Sulawesi Selatan saat ini terdiri dari sistem interkoneksi $70 \mathrm{kV}, 150 \mathrm{kV}, 275 \mathrm{kV}$ dan sistem isolated $20 \mathrm{kV}$ serta sistem tegangan rendah 220 Volt di pulau-pulau terpencil. Sistem interkoneksi tersebut merupakan bagian dari sistem interkoneksi Sulawesi Bagian Selatan (Sulbagsel), dipasok dari PLTU, PLTA, PLTG/GU, PLTD dan PLTMH. Transmisi 275 kV digunakan untuk transfer energi dari PLTA Poso ke Sistem Sulselbar melalui GI Palopo. Sedangkan sistem kecil isolated $20 \mathrm{kV}$ dan 220 Volt di pulau-pulau 
seperti di Kabupaten Selayar, Kabupaten Pangkep, dipasok dari PLTD setempat. Kapasitas terpasang pembangkit di Provinsi Sulawesi Selatan adalah sebesar 1.437 MW (PLN, 2014).

Daya mampu pembangkit yang ada sekitar 1.238 MW, sedangkan beban puncak sampai triwulan III tahun 2014 adalah sebesar 1.186 MW. Jumlah gardu induk eksisting di Sulsel adalah 33 buah dengan kapasitas total 1.583 MVA. Mengenai sistem kelistrikan di Kabupaten Selayar dan pulau-pulau di Kabupaten Pangkep, sepenuhnya dilayani PLTD BBM dengan daya mampu pembangkit sekitar 5,1 MW dan beban puncak hanya 4,2 MW. Rasio elektrifikasi di Provinsi Sulawesi Selatan sampai dengan bulan September 2014 sebesar 82,33\%. Pada lampiran 18 ditunjukkan pembangkit listrik yang ada di Provinsi Sulawesi Selatan dan jumlah kapasitas energi yang dihasilkan.

Kondisi pembangkit listrik saat ini memegang peranan penting dalam pembangunan roda perekonomian di Sulawesi Selatan. Maka dari itu PLN telah merencanakan pembangunan pembangkit listrik secara bertahap. Pada tabel 4.1 ditunjukkan rencana pengembangan ketenagalistrikan di Sulawesi Selatan. 
Tabel 4.1 Rencana Pembangkit Listrik Sulawesi Selatan

\begin{tabular}{|r|l|c|c|c|c|}
\hline NO & \multicolumn{1}{|c|}{ PROYEK } & $\begin{array}{c}\text { ASUMSI } \\
\text { PENGEMBANG }\end{array}$ & JENIS & $\begin{array}{c}\text { KAPASITAS } \\
(\text { MW) }\end{array}$ & COD \\
\hline 1 & Mabile PP Sulsel (Tallo Lama) & PLTG/MG & PLN & 100 & 2016 \\
2 & Mabine PP Sulsel (Tello) & PLTGMG & PLN & 50 & 2016 \\
3 & Selayar & PLTMG & PLN & 10 & 2017 \\
4 & Sulsel Barru - 2 & PLTU & PLN & $1 \times 100$ & 2018 \\
5 & Bakaru 2 & PLTA & PLN & $2 \times 63$ & 2020 \\
6 & Makass ar Peaker & PLTGU & PLN & 450 & $2017 / 18$ \\
7 & Punagaya (FTP2) & PLTU & PLN & $2 \times 100$ & $2017 / 18$ \\
8 & Sulsel Peaker & PLTGU & PLN & 450 & $2018 / 19$ \\
9 & Sulsel 2 & PLTU & PLN & $2 \times 200$ & $2019 / 20$ \\
10 & Poko & PLTA & PLN & $2 \times 117$ & 2021 \\
11 & PLTM Tersebar Sulsel & PLTM & Swasta & 10,5 & 2015 \\
12 & Wajo & PLTMG & Swasta & 20 & 2016 \\
13 & PLTM Tersebar Sulsel & PLTM & Swasta & 26,5 & 2017 \\
14 & PLTM Tersebar Sulsel & PLTM & Swasta & 23 & 2018 \\
15 & PLTM Tersebar Sulsel & PLTM & Swasta & 10 & 2019 \\
16 & PLTM Tersebar Sulsel & PLTM & Swasta & 25 & 2020 \\
17 & Malea (FTP 2) & PLTA & Swasta & $2 \times 45$ & 2020 \\
18 & Bonto Batu (FTP 2) & PLTA & Swasta & $1 \times 110$ & 2024 \\
19 & Jenepanto 2 & PLTU & Swasta & $2 \times 125$ & $2018 / 19$ \\
20 & Salu Uro & PLTA & Swasta & $2 \times 47,5$ & $2020 / 21$ \\
21 & Kalaena 1 & PLTA & Swasta & $2 \times 26,5$ & $2021 / 22$ \\
22 & Palaleng & PLTA & Swasta & $2 \times 20$ & $2021 / 22$ \\
23 & Buttu Batu & PLTA & Swasta & 200 & $2022 / 23$ \\
24 & Seko 1 & PLTA & Swasta & 480 & $2023 / 24$ \\
25 & Selayar & PLTMG & Una/located & 10 & 2024 \\
\hline & JUMLAH & & 3.564 & \\
\hline
\end{tabular}

Sumber : PLN, 2014

\subsection{Model}

Pada Bab III telah dijelaskan mengenai model yang digunakan adalah Model adalah LEAP ( Long-Range Energy Alternatives Planning) dengan pola model yang disusun adalah sebagai berikut pada gambar 4.7. 


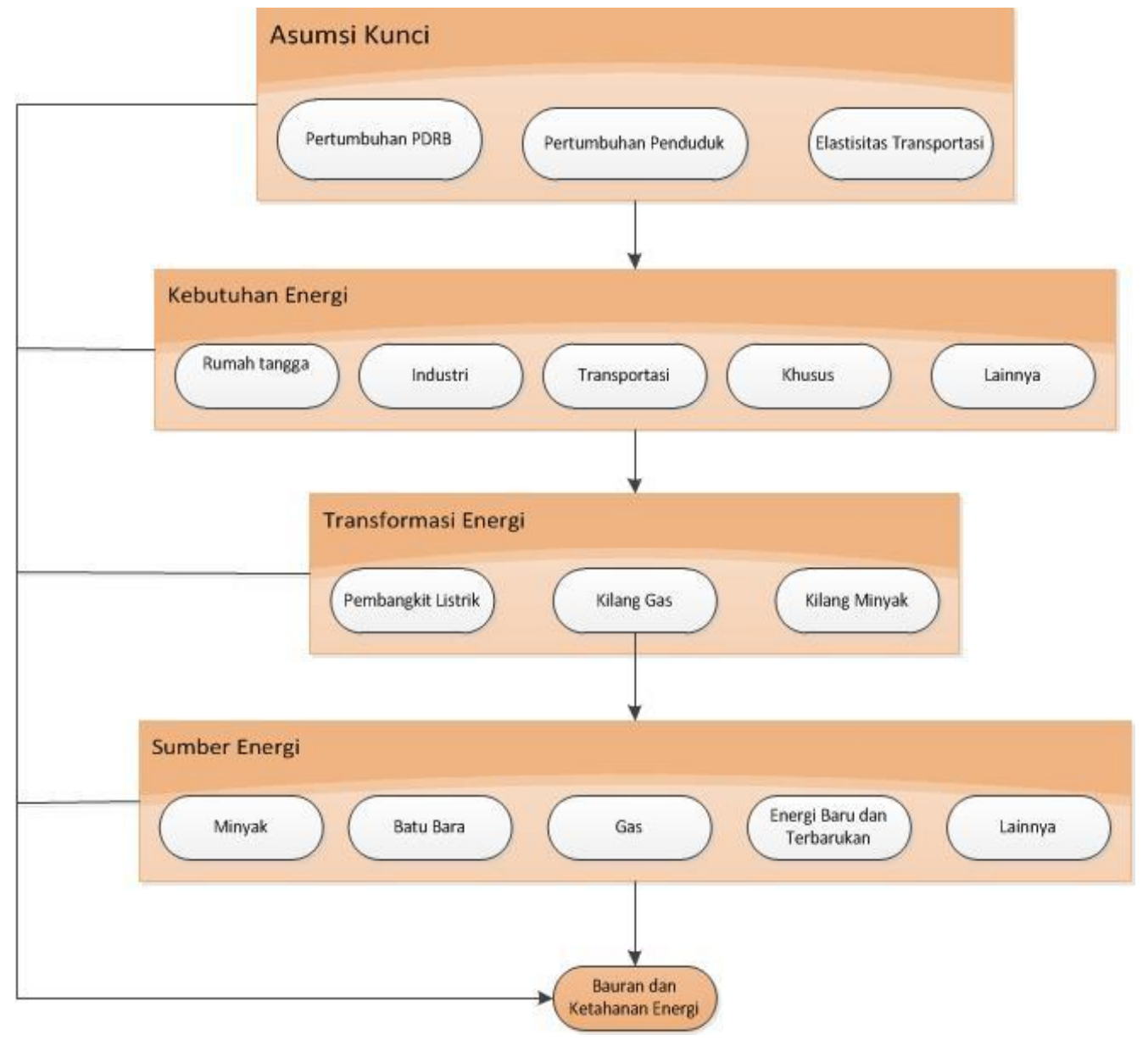

Gambar 4.7 Model LEAP Energi Sulawesi Selatan

\subsubsection{Asumsi Dasar}

Indikator yang digunakan dalam penyusunan sistem energi Sulawesi selatan adalah indikator ekonomi makro, energi, demografi, dan kebijakan di bidang energi, dengan beberapa asumsi sebagai berikut :

- Jumlah penduduk yang ada di Provinsi Sulawesi Selatan adalah 8.034.780 jiwa yang ada pada sektor rumah tangga.

- Jumlah perusahaan yang beroperasi pada sektor industri adalah sebanyak 291 unit berdasarkan golongan industri. 
- Jenis kendaraan dibagi tiga yaitu darat, laut, dan udara. Kendaraan darat seperti motor, mobil, bus dan truk. Kendaraan laut adalah kapal laut yang ada pada pelabuhan. Kendaraan udara adalah pesawat yang ada pada bandar udara Sultan Hasanuddin.

- Pada sektor khusus adalah jasa komersial, keuangan, dan sosial.

- Laju pertumbuhan penduduk mengikuti data BPS.

- Kebutuhan energi sektor industri dipengaruhi oleh nilai tambah pada PDRB.

- Kebutuhan energi sektor transportasi darat berdasarkan jumlah kendaraan. Untuk transportasi laut dan udara dipengaruhi oleh PDRB.

- Pada parameter proyeksi sistem energi bersih ini menggunakan parameter penurunan harga minyak mentah Indonesia yang ada pada tahun 2014. Penurunan harga minyak yang fluktuatif mempengaruhi proyeksi untuk kebijakan regional maupun nasional.

\subsubsection{Skenario}

Proyeksi kebutuhan energi nasional dilakukan dengan menggunakan dua pendekatan, yaitu menggunakan skenario dasar (Business as Usual/BaU) dan skenario clean energy atau energi bersih. Hal ini dimaksudkan untuk mendapatkan perbandingan dari dua kondisi proyeksi. Pada tabel 4.2 ditujukkan perbandingan dari kedua skenario tersebut. 
Tabel 4.2 Perbandingan Skenario

\begin{tabular}{|c|c|c|}
\hline No & Business as Usual (BaU) & Clean Energy (CE) \\
\hline 1 & $\begin{array}{l}\text { Pada sektor transportasi } \\
\text { tidak mengalami perubahan } \\
\text { sumber bahan bakar yaitu } \\
\text { BBM }\end{array}$ & $\begin{array}{l}\text { Pada sektor transportasi } \\
\text { khususnya kendaraan } \\
\text { roda empat sumber } \\
\text { bahan bakar BBM } \\
\text { diganti dengan BBG } \\
\text { dengan peningkatan } \\
\text { hingga } 6 \% \text { pada tahun } \\
2050 \text { sesuai dengan } \\
\text { KEN }\end{array}$ \\
\hline 2 & $\begin{array}{l}\text { Pada sektor transportasi } \\
\text { untuk jenis angkutan darat } \\
\text { kereta api belum ada }\end{array}$ & $\begin{array}{l}\text { kereta api telah } \\
\text { digunakan pada tahun } \\
2030 \text { sebagai angkutan } \\
\text { umum }\end{array}$ \\
\hline 3 & $\begin{array}{l}\text { Pembangkit Listrik tidak } \\
\text { mengalami penambahan } \\
\text { jumlah sesuai dengan } \\
\text { RUPTLN }\end{array}$ & $\begin{array}{l}\text { Pembangkit listrik } \\
\text { dikembangkan sesuai } \\
\text { dengan RUPTLN }\end{array}$ \\
\hline 4 & $\begin{array}{l}\text { Energi Baru Terbarukan } \\
\text { (EBT) masih bersifat off- } \\
\text { grid / belum tersambung } \\
\text { pada jaringan PLN }\end{array}$ & $\begin{array}{l}\text { pembangkit listrik EBT } \\
\text { telah on-grid / } \\
\text { tersambung pada } \\
\text { jaringan PLN dengan } \\
\text { jumlah kapasitas yang } \\
\text { sesuai dengan potensi } \\
\text { pada tahun } 2050\end{array}$ \\
\hline 5 & $\begin{array}{l}\text { Batu bara masih diimpor } \\
\text { dari provinsi kalimantan }\end{array}$ & $\begin{array}{l}\text { Asumsi sama dengan } \\
\mathrm{BaU}\end{array}$ \\
\hline 6 & $\begin{array}{l}\text { Bioenergi belum } \\
\text { dimanfaatkan }\end{array}$ & $\begin{array}{l}\text { Potensi bioenergi } \\
\text { dimanfaatkan untuk } \\
\text { desa-desa }\end{array}$ \\
\hline
\end{tabular}

Skenario BaU adalah skenario proyeksi kondisi saat ini, tanpa adanya perubahan kebijakan yang berlaku dan intervensi lainnya yang dapat menekan laju konsumsi. sedangkan skenario Clean Energy adalah skenario dasar, dimana diasumsikan bahwa konsumsi energi final akan berkurang dengan menerapkan program konservasi dan efisiensi energi sesuai dengan target pemerintah dalam kebijakan Energi Nasional (KEN). skenario ini juga meliputi perbaikan dalam 
efisiensi peralatan pada sektor pengguna, sehingga konsumsi energi final memiliki bauran energi baru terbarukan dari pada skenario $\mathrm{BaU}$.

\subsection{Proyeksi Konsumsi Energi Per Sektor}

Pada sisi demand konsumsi energi per sektor merupakan gambaran mengenai penggunaan pada setiap bidang yaitu rumah tangga, transportasi, industri, komersial, khusus, dan lainnya. Gambar 4.8 menunjukkan proyeksi penggunaan secara total dari seluruh sektor.

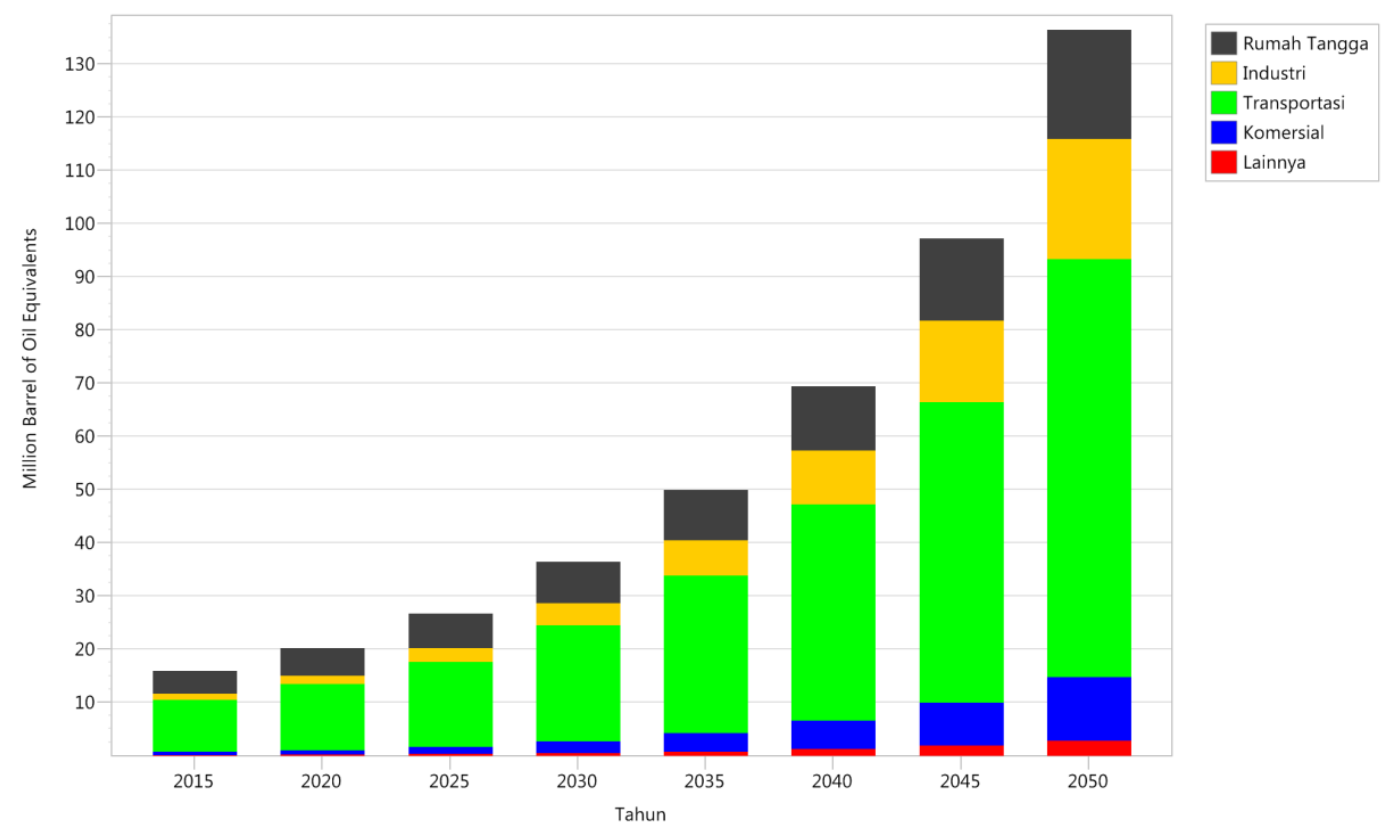

Gambar 4.8 Proyeksi Penggunaan Energi Total Per Sektor

Dari gambar tersebut dapat dilihat bahwa konsumsi energi sektor transportasi merupakan pengguna energi terbanyak dibandingkan dengan sektor yang lain. Pada tabel 4.3 ditunjukkan proyeksi konsumsi energi pada tahun 2025 . 
Tabel 4.3 Proyeksi Konsumsi Energi Per Sektor

\begin{tabular}{|l|c|c|c|c|c|c|c|c|}
\hline \multirow{2}{*}{ Sektor } & \multicolumn{7}{|c|}{ Tahun (Juta SBM) } \\
\cline { 2 - 10 } & 2015 & 2020 & 2025 & 2030 & 2035 & 2040 & 2045 & 2050 \\
\hline $\begin{array}{l}\text { Rumah } \\
\text { Tangga }\end{array}$ & 4,119 & 5,043 & 6,310 & 7,604 & 9,379 & 11,859 & 15,375 & 20,426 \\
\hline Industri & 1,131 & 1,681 & 2,647 & 4,217 & 6,596 & 10,131 & 15,275 & 22,611 \\
\hline Transportasi & 9,813 & 12,341 & 15,931 & 21,746 & 29,534 & 40,688 & 56,473 & 78,493 \\
\hline Komersial & 0,598 & 0,889 & 1,400 & 2,230 & 3,488 & 5,357 & 8,077 & 11,956 \\
\hline Lainnya & 0,143 & 0,212 & 0,334 & 0,533 & 0,833 & 1,280 & 1,930 & 2,857 \\
\hline Total & 15,804 & 20,166 & 26,622 & 36,329 & 49,831 & 69,314 & 97,130 & 136,343 \\
\hline
\end{tabular}

Konsumsi energi pada tahun 2025 didominasi oleh sektor Industri, lalu disusul oleh rumah tangga, industri, komersial, dan lainnya. Pada tahun 2050 konsumsi energi pada sektor industri dapat melampaui rumah tangga. Perubahan ini dipengaruhi oleh elastisitas dan tingkat pertumbuhan kebutuhan energi yang ada pada kedua sektor tersebut.

Pada proyeksi kebutuhan energi nasional memiliki bauran energi yang lebih besar. Pada gambar 4.9 ditunjukkan bauran energi per sektor.

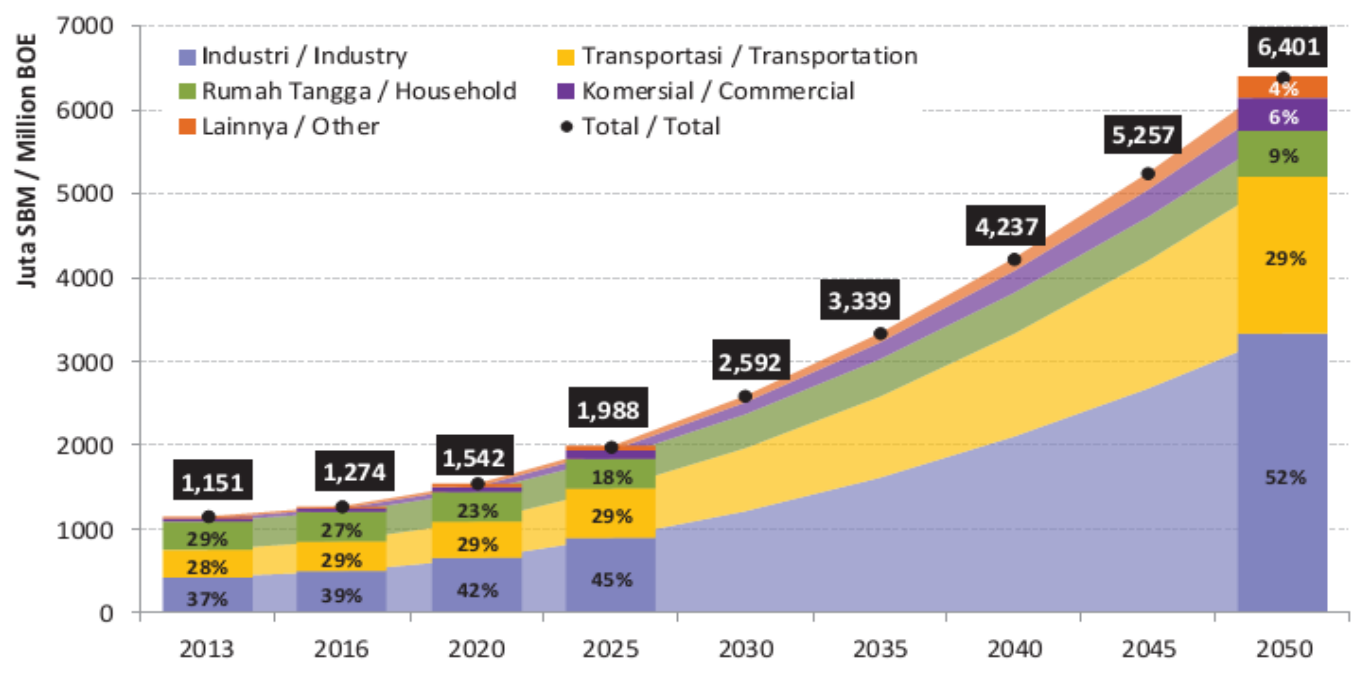

Gambar 4.9 Bauran Energi Nasional

sumber : (Sugiyono, Anindhita, Boedoyo, \& Adiarso, 2014) 


\subsubsection{Konsumsi Energi Sektor Rumah Tangga}

Pada sektor rumah tangga dengan jumlah populasi penduduk adalah 8034776 jiwa. Dalam sektor rumah tangga terdapat sub sektor yaitu golongan dibawah garis kemiskinan $(10,1 \%)$, bawah $(32,8 \%)$, menengah $(41,3 \%)$, dan atas $(15,9 \%)$. Pada sektor rumah tangga menggunakan jenis energi listrik, minyak tanah, gas bumi, dan LPG. Pada gambar 4.10 ditunjukkan proyeksi penggunaan energi sektor rumah tangga.

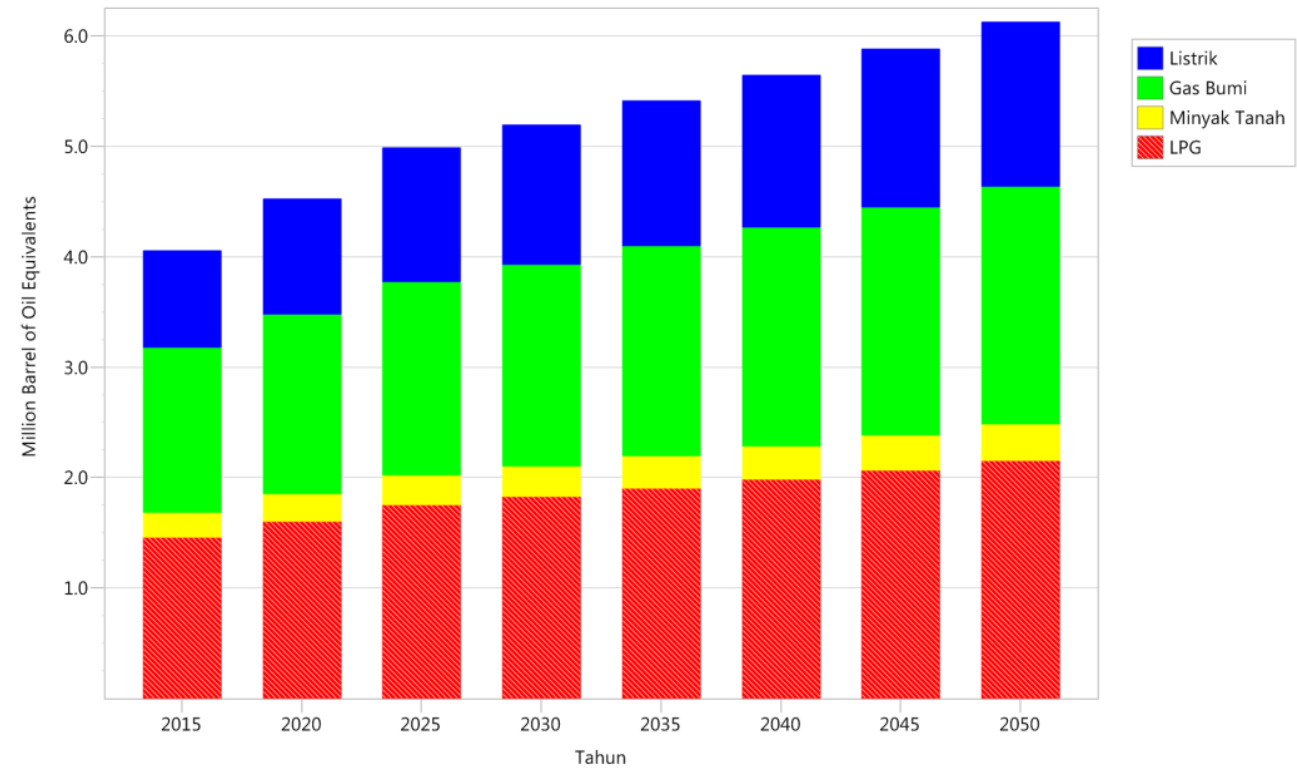

Gambar 4.10 Konsumsi Energi Pada Sektor Rumah Tangga Skenario BaU

Pada gambar tersebut menunjukkan konsumsi energi yang masih sangat dominan yaitu gas bumi yang merupakan sumber energi fosil. Penggunaan energi fosil saat ini masih tidak tergantikan pada sektor rumah tangga karena sumber energi tersebut disubsidi langsung oleh pemerintah. 
Tabel 4.4 Konsumsi Energi Jenis Sektor Rumah Tangga

\begin{tabular}{|l|c|c|c|c|c|c|c|c|}
\hline \multirow{2}{*}{ Jenis Energi } & \multicolumn{7}{|c|}{ Tahun ( Juta SBM ) } \\
\cline { 2 - 10 } & 2015 & 2020 & 2025 & 2030 & 2035 & 2040 & 2045 & 2050 \\
\hline Listrik & 0,879 & 1,046 & 1,213 & 1,264 & 1,318 & 1,373 & 1,431 & 1,491 \\
\hline $\begin{array}{l}\text { Gas Bumi } \\
\text { Minyak } \\
\text { Tanah }\end{array}$ & 1,495 & 1,625 & 1,754 & 1,828 & 1,904 & 1,985 & 2,068 & 2,155 \\
\hline LPG & 0,228 & 0,249 & 0,269 & 0,281 & 0,293 & 0,305 & 0,318 & 0,331 \\
\hline & 1,456 & 1,604 & 1,751 & 1,825 & 1,902 & 1,982 & 2,065 & 2,152 \\
\hline Total & 4,058 & 4,524 & 4,987 & 5,197 & 5,416 & 5,644 & 5,882 & 6,130 \\
\hline
\end{tabular}

Pada tabel 4.4 konsumsi energi merupakan hasil dari skenario BaU. Pada skenario Clean Energy (CE) maka penggunaan energi khususnya pada daerah pedesaan yang umumnya terdapat golongan di bawah dan garis kemiskinan telah dapat menggunakan biogas untuk mengganti konsumsi energi jenis gas. Programa ini menyesuaikan dengan Kebijakan Energi Nasional (KEN). Pada gambar 4.11 ditunjukkan skenario CE pada sektor rumah tangga.

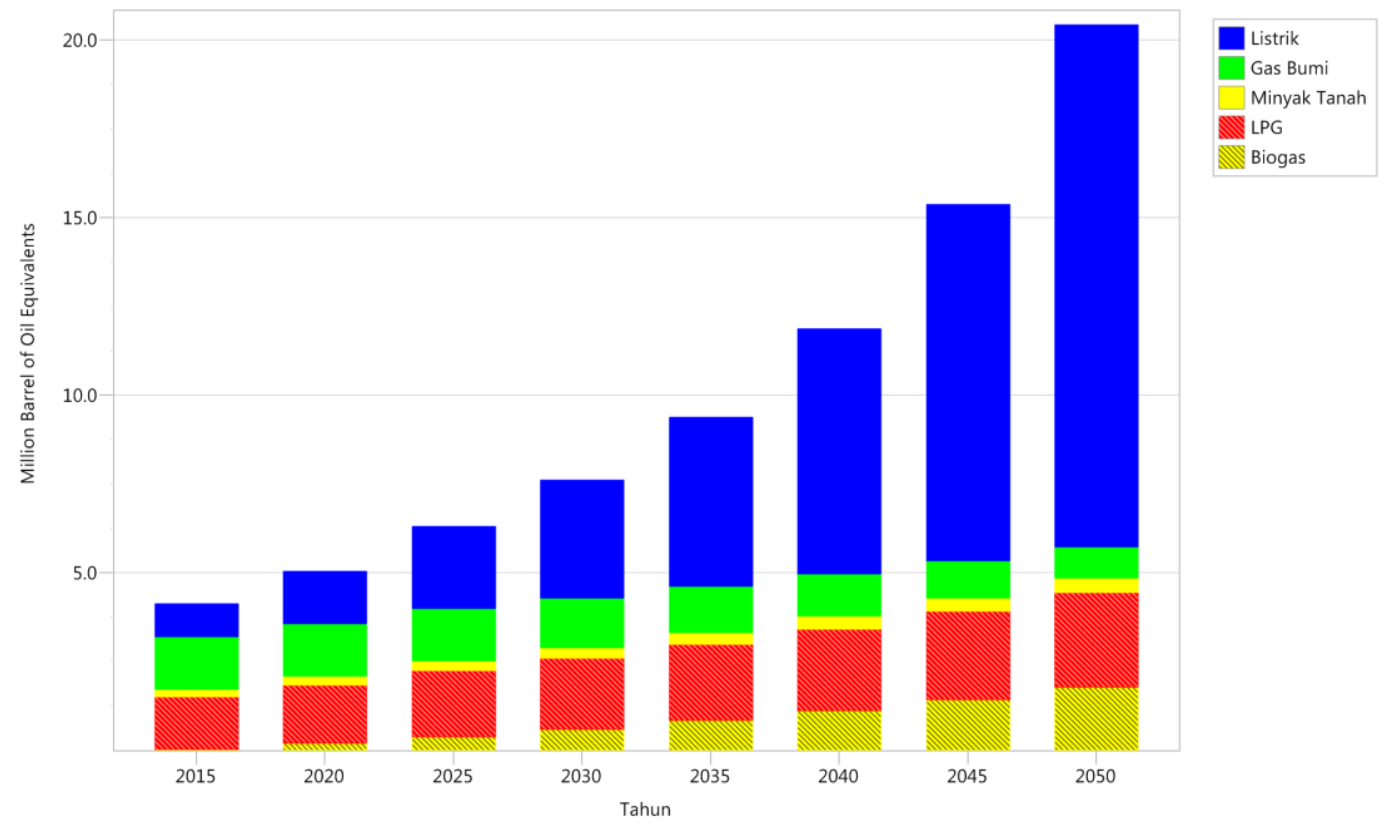

Gambar 4.11 Konsumsi Energi Sektor Rumah Tangga Skenario CE 
Pada skenario CE untuk sektor rumah tangga biogas diperoleh dari limbah komunal dan peternakan. Pada tabel 4.5 ditunjukkan proyeksi skenario CE untuk konsumsi energi rumah tangga.

Tabel 4.5 Konsumsi Energi Jenis Sektor Rumah Tangga Skenario CE

\begin{tabular}{|l|l|l|l|l|l|l|l|l|}
\hline \multirow{2}{*}{ Jenis } & \multicolumn{7}{|c|}{ Tahun ( Juta SBM) } \\
\cline { 2 - 10 } & 2015 & 2020 & 2025 & 2030 & 2035 & 2040 & 2045 & 2050 \\
\hline Listrik & 0,929 & 1,477 & 2,326 & 3,321 & 4,774 & 6,908 & 10,052 & 14,703 \\
\hline Gas Bumi & 1,472 & 1,479 & 1,472 & 1,396 & 1,301 & 1,184 & 1,041 & 0,870 \\
\hline $\begin{array}{l}\text { Minyak } \\
\text { Tanah }\end{array}$ & 0,228 & 0,255 & 0,285 & 0,306 & 0,330 & 0,354 & 0,381 & 0,410 \\
\hline LPG & 1,462 & 1,646 & 1,851 & 1,991 & 2,141 & 2,303 & 2,478 & 2,665 \\
\hline Biogas & 0,028 & 0,186 & 0,377 & 0,590 & 0,833 & 1,109 & 1,423 & 1,777 \\
\hline Total & 4,119 & 5,043 & 6,310 & 7,604 & 9,379 & 11,859 & 15,375 & 20,426 \\
\hline
\end{tabular}

Pada sektor rumah tangga skala nasioanal ditunjukkan pada gambar 4.12 . proyeksi kebutuhan energi nasional pada sektor rumah tangga didominasi oleh energi listrik.

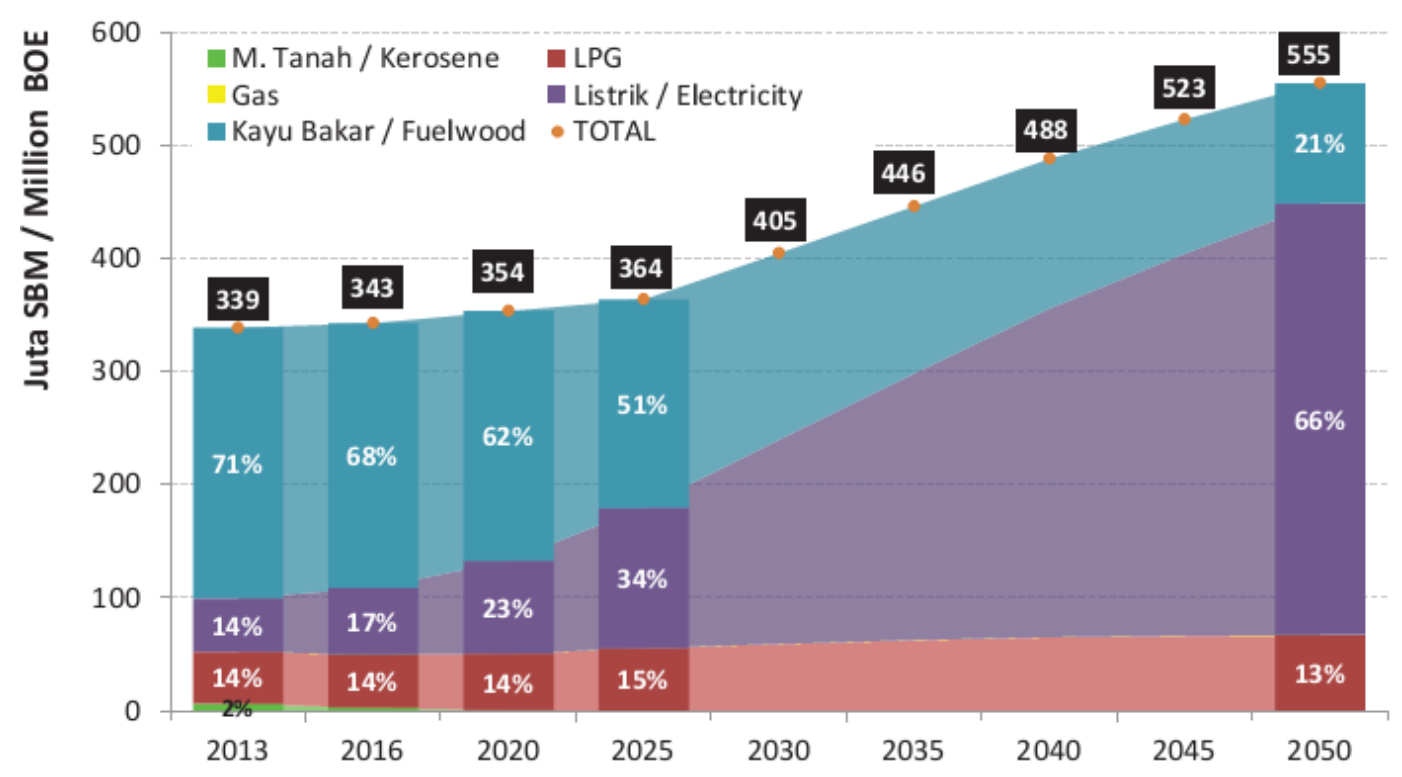

Gambar 4.12 Konsumsi Energi Sektor Rumah Tangga Nasional

Sumber :(Sugiyono et al., 2014) 


\subsubsection{Konsumsi Energi Sektor Industri}

Pada sektor industri merupakan sektor yang menghasilkan PDRB tertinggi di Sulawesi Selatan. Pada sektor ini memiliki 291 unit Industri yang terbagi dari 17 jenis kegiatan industri yaitu :

1. Makanan;

2. Minuman;

3. Tembakau

4. Tekstil;

5. Pakaian kulit;

6. Kayu;

7. Kertas

8. Percetakan;

9. Kimia;

10. Karet;

11. Non logam;

12. Logam;

13. Barang non logam bukan mesin;

14. Listrik dan motor;

15. Alat angkutan;

16. Furniture;

17. Pengolahan. 
Pada golongan jenis industri non logam merupakan industri yang mengkonsumsi energi paling banyak yaitu 1.051.000 SBM pada tahun 2014. Pada gambar 4.13 ditunjukkan proyeksi konsumsi energi sektor industri secara total.

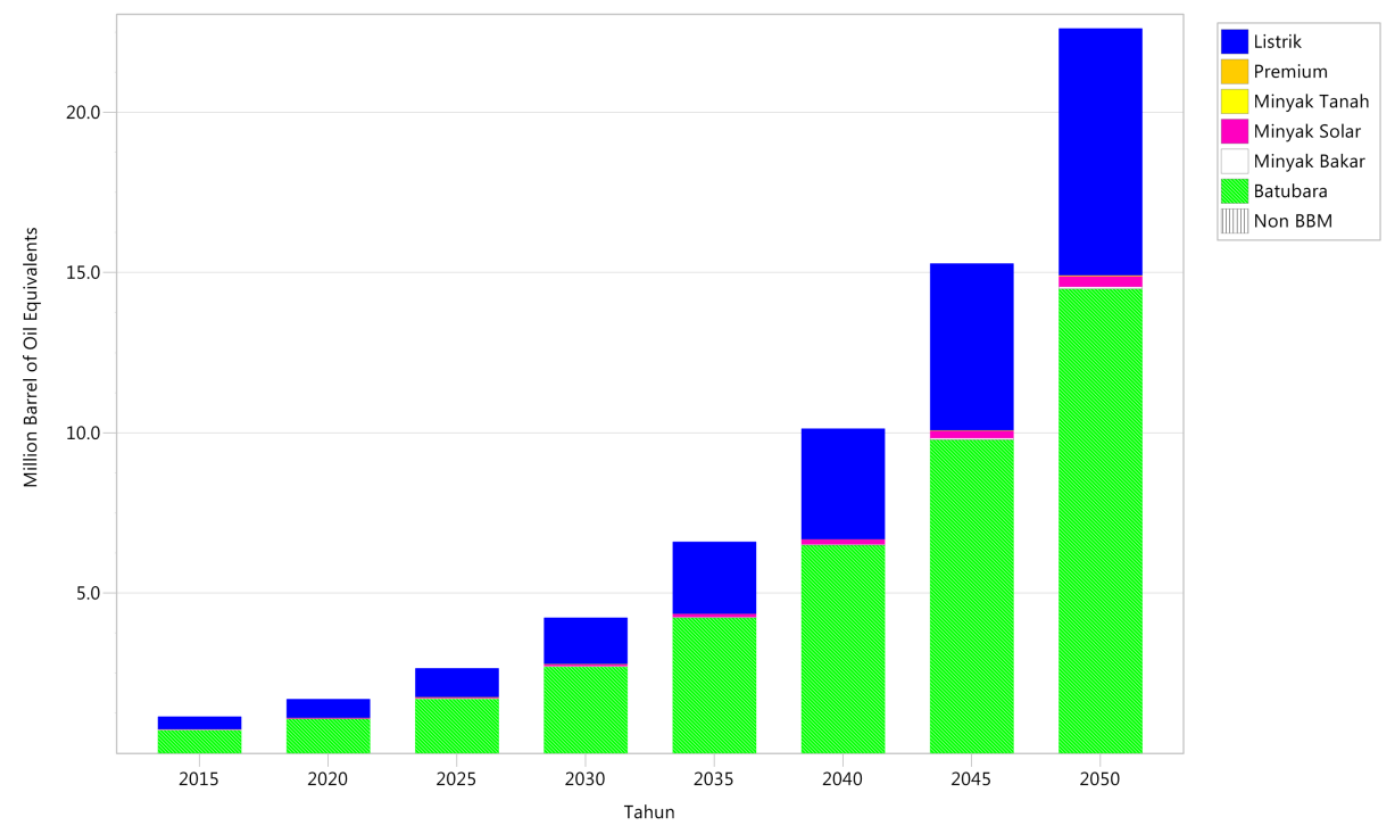

Gambar 4.13 Konsumsi Energi Sektor Industri

Pada sektor industri skenario CE diasumsikan sama dengan skenari BaU sehingga penggunaan atau konsumsi energi terbarukan pada sektor ini tidak ada. Pada tabel 4.6 ditunjukkan konsumsi semua energi pada sektor industri.

Tabel 4.6 Konsumsi Energi Jenis Sektor Industri

\begin{tabular}{|l|c|c|c|c|c|c|c|r|}
\hline \multirow{2}{*}{ Jenis Energi } & \multicolumn{7}{|c|}{ Tahun (Juta SBM ) } \\
\cline { 2 - 10 } & 2015 & 2020 & 2025 & 2030 & 2035 & 2040 & 2045 & 2050 \\
\hline Listrik & 0,385 & 0,572 & 0,901 & 1,435 & 2,245 & 3,448 & 5,200 & 7,697 \\
\hline Premium & 0,001 & 0,001 & 0,002 & 0,003 & 0,004 & 0,006 & 0,009 & 0,014 \\
\hline \multirow{2}{*}{ Minyak Tanah } & 0,000 & 0,000 & 0,001 & 0,001 & 0,002 & 0,003 & 0,004 & 0,006 \\
\hline
\end{tabular}


Tabel 4.6 Konsumsi Energi Jenis Sektor Industri (Lanjutan)

\begin{tabular}{|l|c|c|c|c|c|c|c|c|}
\hline \multirow{2}{*}{ Jenis Energi } & \multicolumn{7}{|c|}{ Tahun (Juta SBM) } \\
\cline { 2 - 10 } & 2015 & 2020 & 2025 & 2030 & 2035 & 2040 & 2045 & 2050 \\
\hline Minyak Solar & 0,017 & 0,025 & 0,040 & 0,063 & 0,099 & 0,152 & 0,229 & 0,340 \\
\hline Minyak Bakar & 0,003 & 0,005 & 0,008 & 0,013 & 0,020 & 0,031 & 0,047 & 0,070 \\
\hline Batubara & 0,724 & 1,077 & 1,696 & 2,702 & 4,226 & 6,490 & 9,786 & 14,485 \\
\hline Total & 1,131 & 1,681 & 2,647 & 4,217 & 6,596 & 10,131 & 15,275 & 22,611 \\
\hline
\end{tabular}

Pada tabel 4.6 Batu bara merupakan jenis energi yang paling banyak digunakan pada sektor industri karena merupakan bahan bakar yang digunakan sebagai pemanas pada boiler mesin penggerak yang ada setiap sub industri. Bahan bakar fosil ini diasumsikan mengimpor dari daerah luar Sulawesi Selatan yaitu Kalimantan.

Proyeksi kebutuhan energi pada sektor industri dipengaruhi pula oleh harga minyak dunia. Industri hulu migas saat ini lebih banyak menunggu atau menunda proyek hulu migas, baik eksploitasi maupun eksplorasi blok migas. Karena banyak proyek hulu migas nilai keekonomiannya mencapai 60 dolar AS per barel, harga minyak turun terus di bawah USD 50 per barel (Sahrul, 2015). Penurunan harga minyak mempengaruhi aktivitas industri nasioanal mau pun regional.

Harga batu bara turut mempengaruhi aktivitas di sektor industri. Penurunan harga batu bara membuat banyak perusahaan batu bara menjadi gulung tikar sehingga produksi batu bara dikurangi (Vicharus Dianjiwa, 2015). 
Pada konsumsi energi sektor industri skala nasional diperkirakan gas akan berkembang sebesar 5,6\% baik sebagai bahan bakar maupun bahan baku. Peranan batu bara di sektor industri cukup tinggi karena sebagai besar teknologi boiler di industri menggunakan batu bara dengan peningkatan sebesar 5,7\% per tahun atau mendekati 300 juta ton di tahun 2050. Pada gambar 4.14 ditunjukkan berikut.

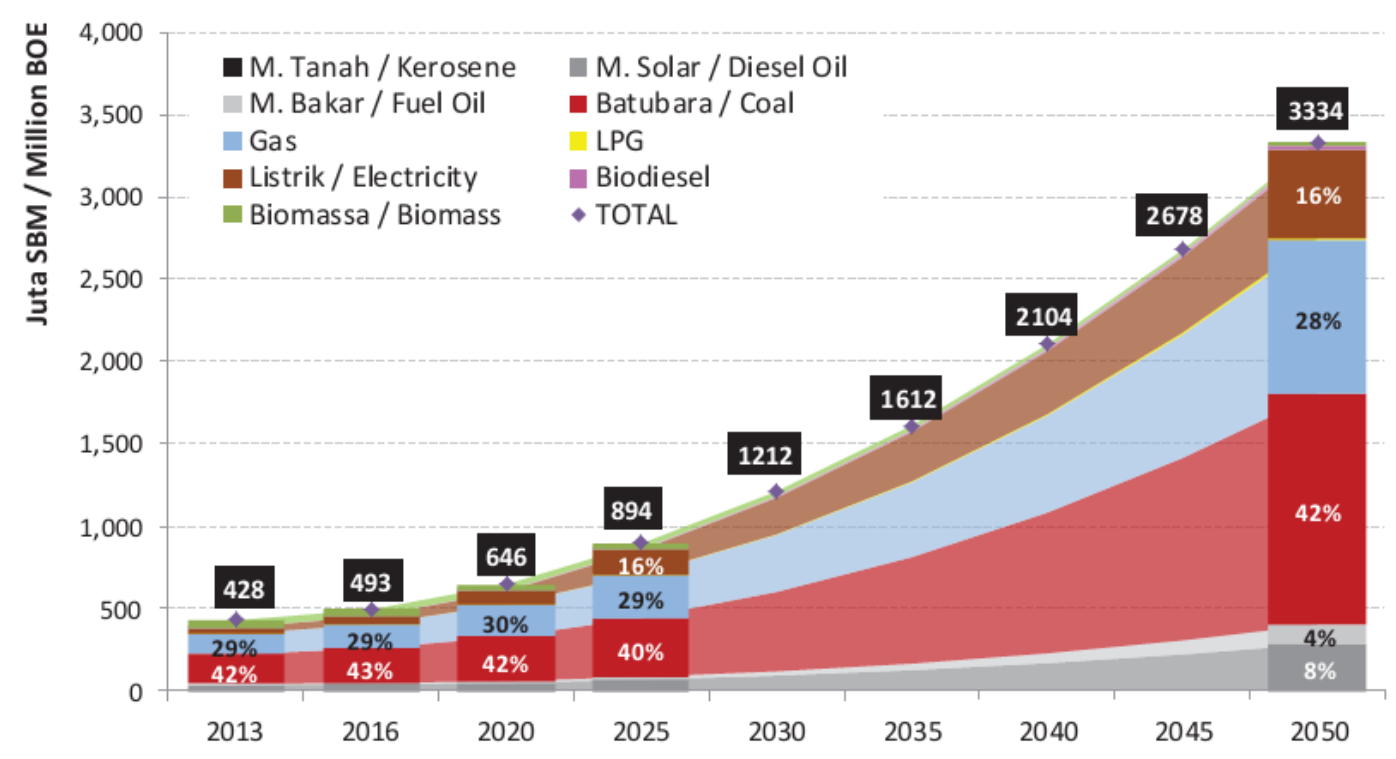

Gambar 4.14 Konsumsi Energi Sektor Industri Nasional

Sumber : (Sugiyono et al., 2014)

\subsubsection{Konsumsi Energi Sektor Transportasi}

Sektor transportasi seperti diketahui lebih dari 50\% (Sugiyono et al., 2014) konsumsi energi di Indonesia dihabiskan oleh sektor transportasi maka Bahan Bakar Minyak (BBM) adalah jenis energi yang sangat vital bagi roda perekonomian di Indonesia maupun di Sulawesi selatan. Pada gambar 4.15 ditunjukkan konsumsi energi pada sektor traportasi menggunakan skenario $\mathrm{BaU}$. 


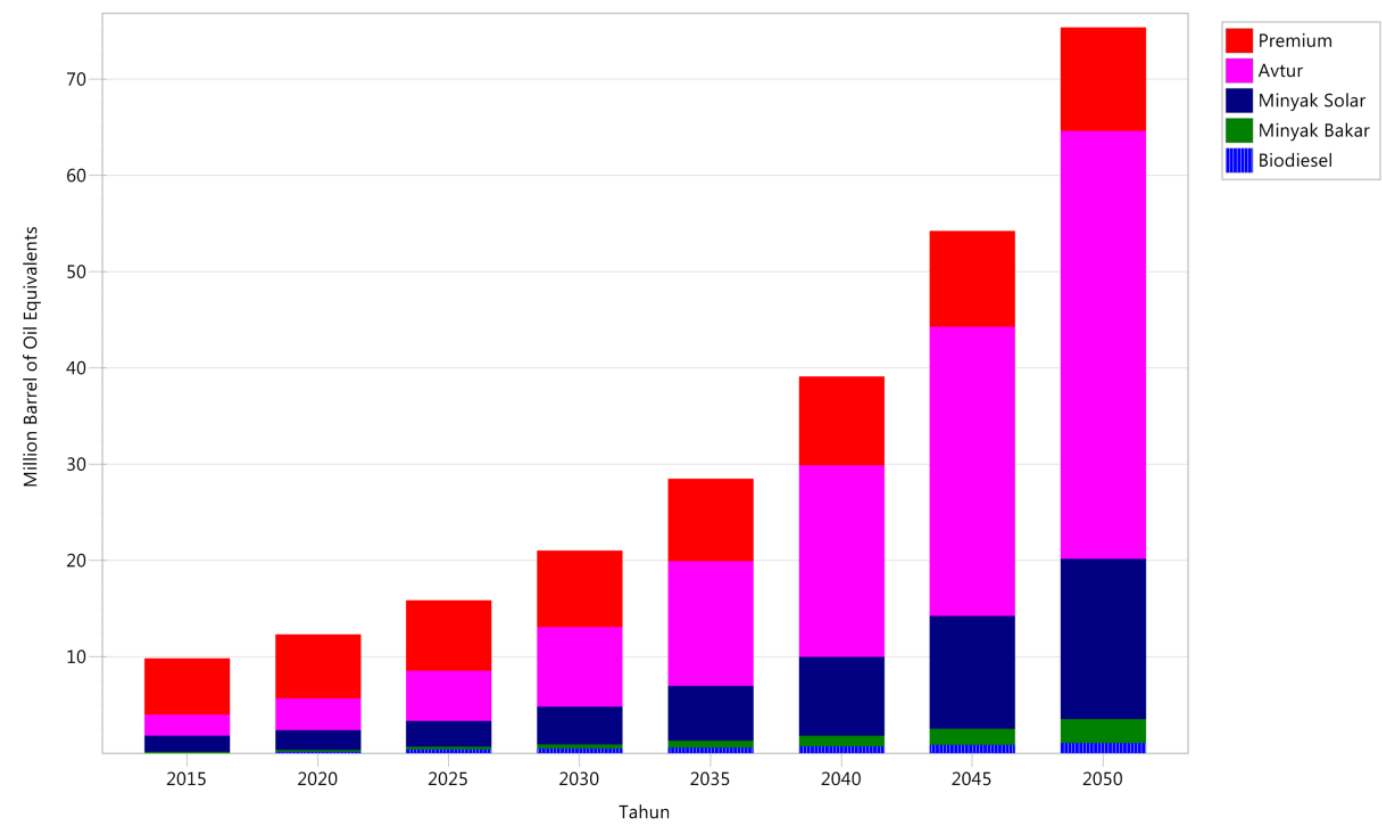

Gambar 4.15 Konsumsi Energi Sektor Transportasi Skenario BaU

Pada sektor tranportasi konsumsi energi dihasilkan dari beberap sub sektor yaitu sepeda motor, mobil penumpang, truk, angkutan laut, dan angkutan udara. Pada gambar di atas avtur merupakan jenis energi yang paling banyak dikonsumsi pada sektor ini. Pada tabel 4.7 ditunjukkan proyeksi detail energi transportasi.

Tabel 4.7 Konsumsi Energi Jenis Sektor Transportasi Skenario BaU

\begin{tabular}{|l|r|r|r|r|r|r|r|r|}
\hline \multirow{2}{*}{ Jenis Energi } & \multicolumn{7}{|c|}{ Tahun ( Juta SBM ) } \\
\cline { 2 - 10 } & 2015 & 2020 & 2025 & 2030 & 2035 & 2040 & 2045 & 2050 \\
\hline Premium & 5,784 & 6,622 & 7,307 & 7,891 & 8,519 & 9,191 & 9,909 & 10,674 \\
\hline Avtur & 2,223 & 3,306 & 5,205 & 8,292 & 12,970 & 19,920 & 30,036 & 44,460 \\
\hline Minyak Solar & 1,648 & 2,032 & 2,684 & 3,904 & 5,666 & 8,183 & 11,734 & 16,673 \\
\hline Minyak Bakar & 0,133 & 0,187 & 0,289 & 0,460 & 0,720 & 1,106 & 1,668 & 2,469 \\
\hline Biodiesel & 0,021 & 0,160 & 0,368 & 0,463 & 0,577 & 0,713 & 0,874 & 1,061 \\
\hline Total & 9,809 & 12,307 & 15,853 & 21,011 & 28,452 & 39,112 & 54,220 & 75,337 \\
\hline
\end{tabular}


Pada tabel 4.7 nilai penggunaan energi terbesar yaitu avtur sebesar 44,460 Juta SBM yang merupakan sumber energi untuk bahan bakar pesawat terbang. Konsumsi dari sektor angkutan udara ini telah melampaui jumlah kebutuhan energi pada sektor angkutan darat seperti motor dan mobil. Bahan bakar jenis premium menjadi sumber energi terbesar kedua yang dipengaruhi oleh kendaraan angkutan darat yang tiap tahun semakin bertambah.

Konsumsi avtur semakin besar seiring dengan peningkatan jumlah penumpang di bandara Sultan Hasanuddin sebesar 6,4\% selama periode 20102015. Meningkatnya jumlah penumpang di bandara Sultan Hasanuddin berbanding lurus dengan jumlah jarak yang semakin banyak ditempuh asumsi satu maskapai penerbangan dapat mengkonsumsi 1,7 Milyar liter avtur per tahun yaitu garuda (Sri Lestari, 2015)

Kondisi ini diperparah dengan tak adanya aturan pembatasan umur kendaraan yang tetap di pemerintah Indonesia maupun Sulawesi selatan. Skenario CE digunakan untuk mengatasi hal tersebut yaitu dengan mengganti secara peralahan penggunaan bahan bakar jenis premium dengan bioetanol dan solar dengan biodiesel untuk kendaraan roda dua dan roda empat. Penerapan BBG untuk kendaraan roda empat harus diikuti kebijakan dengan asumsi bahwa seluruh jalan yang dilalui sudah datar dan halus karena jika jalan tidak layak masih banyak kubangan atau tidak rata akan dapat mengurangi tingkat keamanan pada kendaraan roda empat tersebut. Kebijakan yang diterapkan untuk meningkatkan sistem energi bersih pada sektor transportasi yaitu penggunaan bahan bakar E5 atau etanol $5 \%$ yang memiliki nilai oktan 100 dapat meningkatkan efisiensi pada 
kendaraan. Pada gambar 4.16 ditunjukkan proyeksi kebijakan energi pada sektor transportasi.

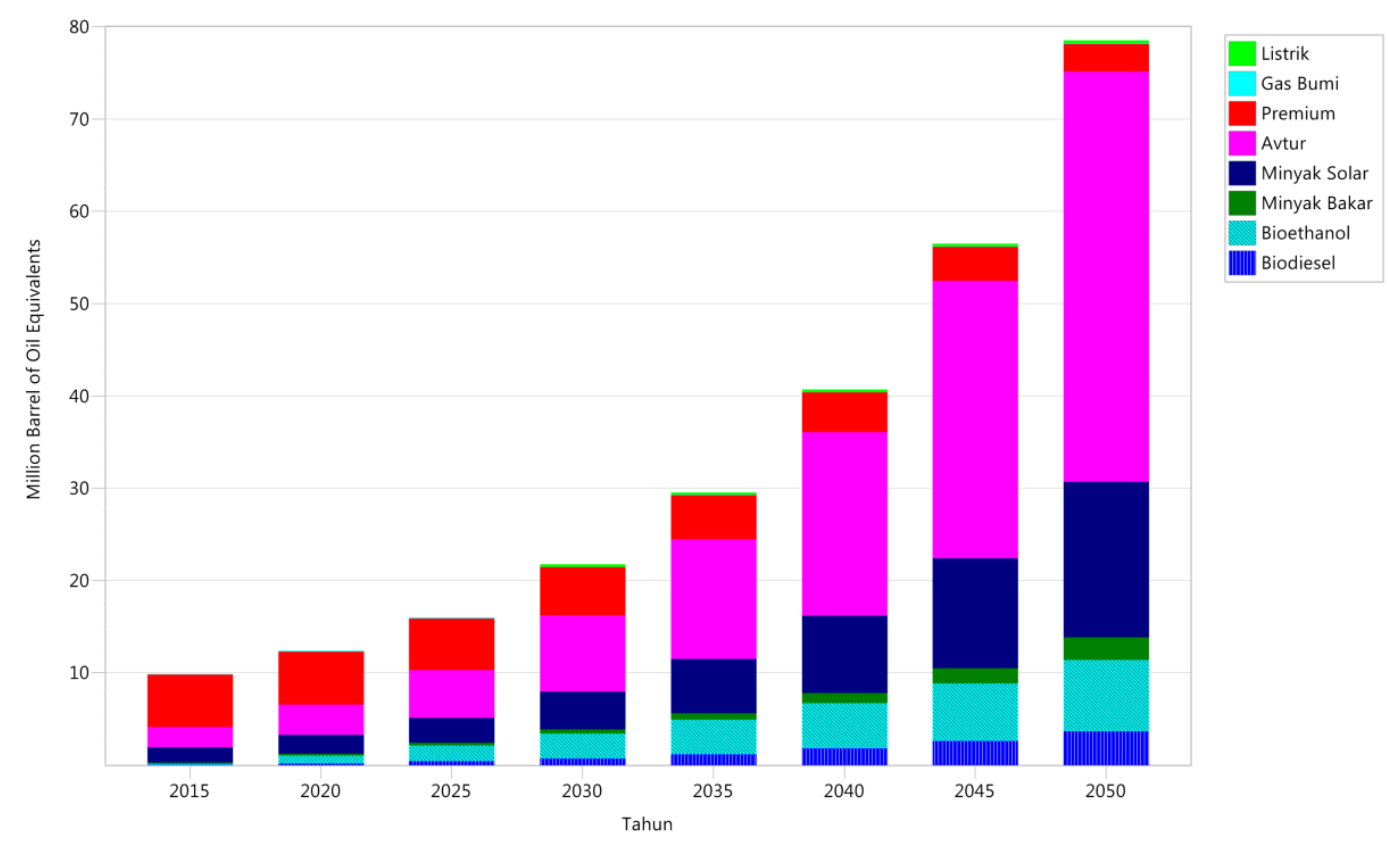

Gambar 4.16 Konsumsi Energi Sektor Transportasi Skenario CE

Gambar sebelumnya menunjukkan bauran energi dengan digunakannya produk energi terbarukan yaitu bioetanol dan biodiesel yang berasal dari potensi sumber hayati yang nanti dapat menurunkan konsumsi pada sektor premium dan diesel. Pada skenario ini konsumsi energi listrik telah pada tahun 2030 seiring dengan ranjangan pembangunan kereta api listrik trans Sulawesi selatan. Pada tabel 4.8 ditunjukkan konsumsi energi menggunakan skenario CE. 
Tabel 4.8 Konsumsi Energi Jenis Sektor Transportasi Skenario CE

\begin{tabular}{|l|r|r|r|r|r|r|r|r|}
\hline \multirow{2}{*}{ Jenis Energi } & \multicolumn{7}{|c|}{ Tahun ( Juta SBM ) } \\
\cline { 2 - 10 } & 2015 & 2020 & 2025 & 2030 & 2035 & 2040 & 2045 & 2050 \\
\hline Listrik & - & - & - & 0,237 & 0,237 & 0,237 & 0,237 & 0,237 \\
\hline Gas Bumi & 0,001 & 0,005 & 0,012 & 0,021 & 0,032 & 0,046 & 0,063 & 0,085 \\
\hline Premium & 5,651 & 5,749 & 5,588 & 5,230 & 4,802 & 4,293 & 3,693 & 2,991 \\
\hline $\begin{array}{l}\text { Avtur } \\
\text { Minyak }\end{array}$ & 2,223 & 3,306 & 5,205 & 8,292 & 12,970 & 19,920 & 30,036 & 44,460 \\
\hline $\begin{array}{l}\text { Minyak } \\
\text { Bakar }\end{array}$ & 1,648 & 2,032 & 2,684 & 4,090 & 5,852 & 8,368 & 11,920 & 16,859 \\
\hline $\begin{array}{l}\text { Bioethanol } \\
\text { Biodiesel }\end{array}$ & 0,133 & 0,187 & 0,289 & 0,460 & 0,720 & 1,106 & 1,668 & 2,469 \\
\hline \begin{tabular}{l} 
Total \\
\hline
\end{tabular} & 0,025 & 0,188 & 0,434 & 0,754 & 1,205 & 1,821 & 2,641 & 3,710 \\
\hline
\end{tabular}

Proyeksi kebutuhan energi sektor transportasi pada skala nasional berasumsi bahwa pemakaian premium dan minyak diesel terus meningkat dengan laju 3,9\% dan 5,6\% per tahun. Hingga 2050 laju pertumbuhan avtur dan minyak bakar diperkirakan sekitar 4,4\% dan 4,8\%. Penggunaan gas dan listrik mulai dikembangkan sesuai dengan kebutuhan. Pada gambar 4.17 ditunjukkan proyeksi kebutuhan sektor transportasi. 


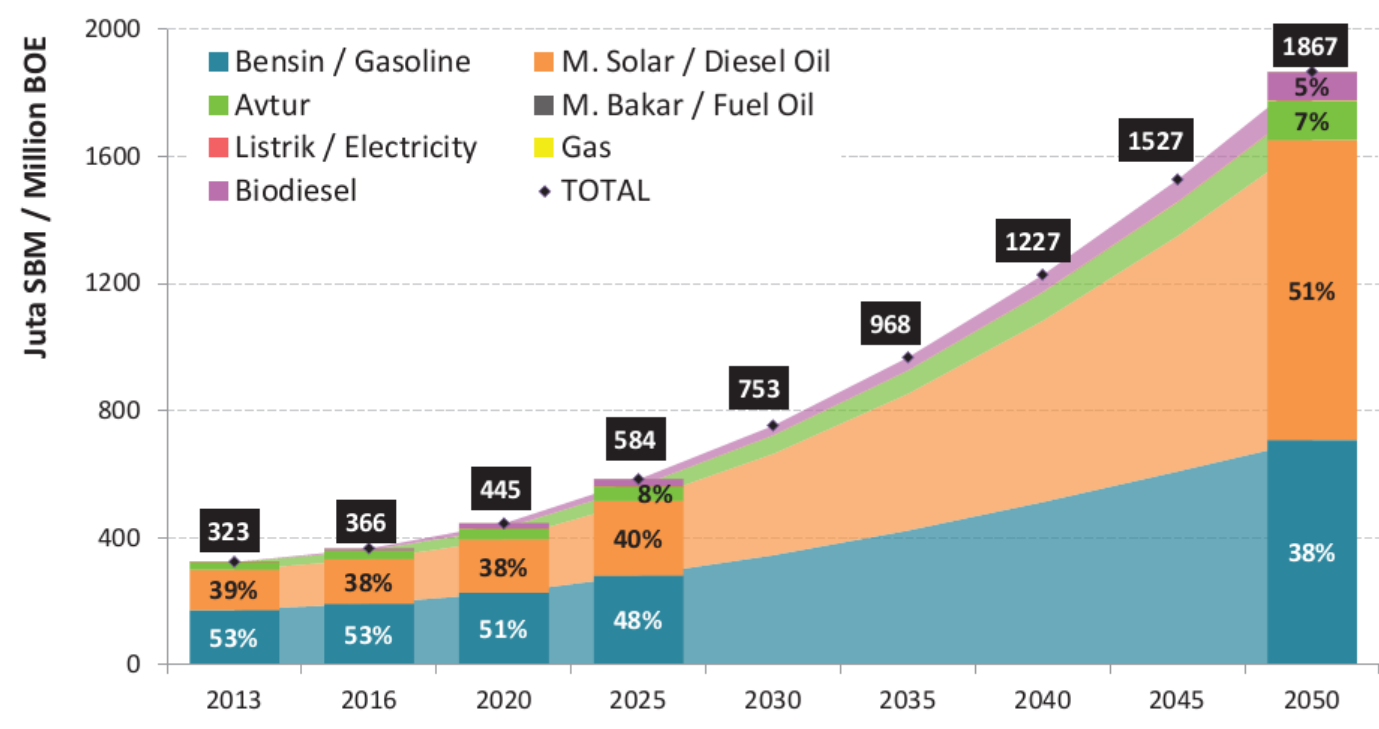

Gambar 4.17 Konsumsi Energi Sektor Transportasi Nasional

Sumber : (Sugiyono et al., 2014)

\subsubsection{Konsumsi Energi Sektor Komersial}

Pada sektor ini merupakan sektor yang terdiri dari jasa komersial, keuangan dan jasa sosial. Sektor ini merupakan sektor pengguna energi terbesar ketiga di Sulawesi Selatan setelah Industri. Jasa komersial ini merupakan gambaran konsumsi energi pada industri kecil menengah dan usaha kecil menengah. Pengguna energi ini pada umumnya berada pada perkotaan.

Pada sub sektor keuangan adalah merujuk pada industri keuangan seperti bank, koperasi simpan pinjam, dan lain-lain. Sub sektor sosial adalah merujuk pada sektor fasilitas publik, kemasyarakatan maupun keagamaan. Pada gambar 4.18 ditunjukkan proyeksi pengguna energi pada sektor komersial. 


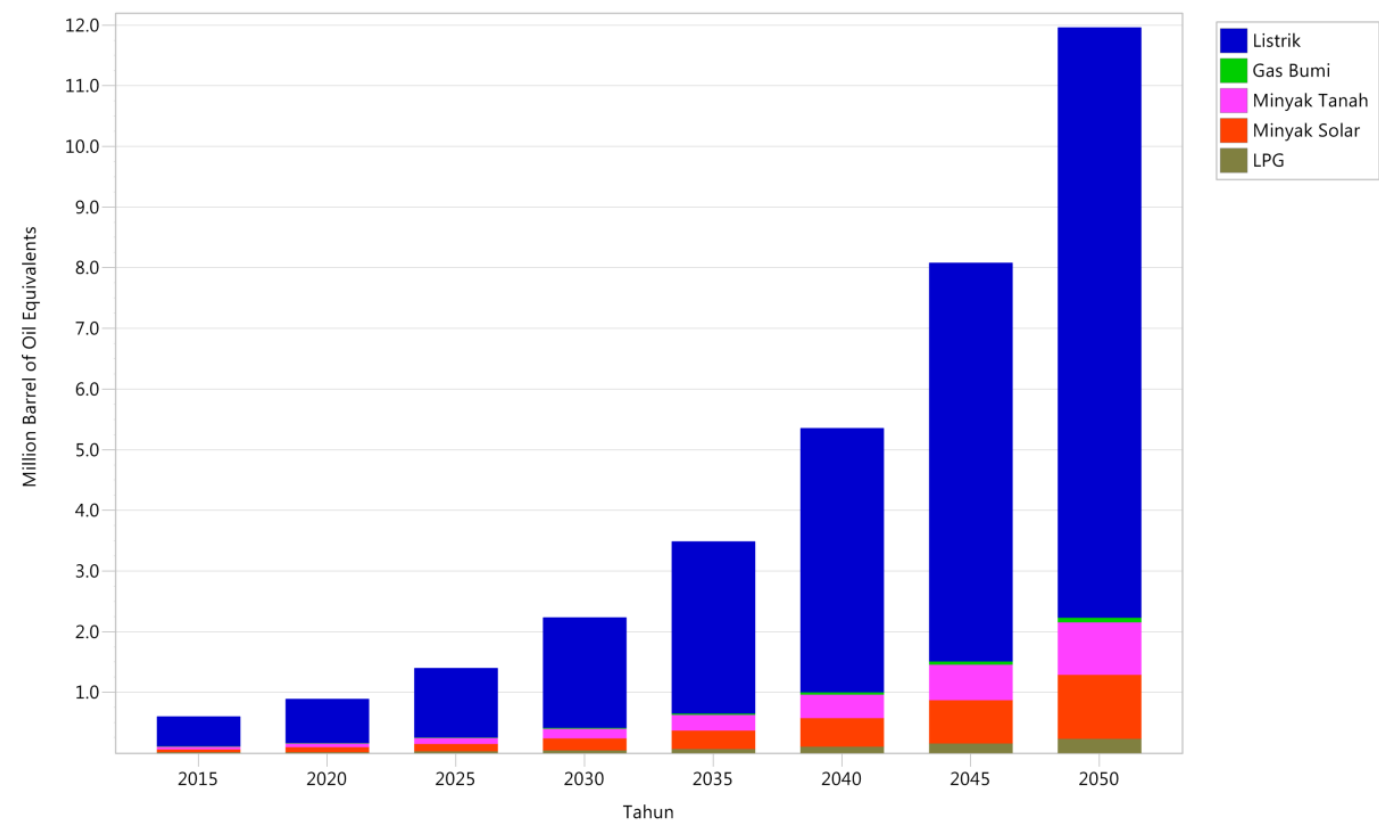

Gambar 4.18 Konsumsi Energi Sektor Komersial

Pada gambar ditunjukkan penggunaan konsumsi energi listrik merupakan energi yang paling banyak digunakan setiap tahun. Pada sektor komersial ini skenario BaU diasumsikan sama dengan CE. Pada tabel 4.9 ditunjukkan mengenai detail konsumsi energi pada sektor komersial.

Tabel 4.9 Konsumsi Energi Jenis Sektor Komersial

\begin{tabular}{|l|c|c|c|c|c|c|c|r|}
\hline \multirow{2}{*}{ Jenis Energi } & \multicolumn{7}{|c|}{ Tahun ( Juta SBM ) } \\
\cline { 2 - 10 } & 2015 & 2020 & 2025 & 2030 & 2035 & 2040 & 2045 & 2050 \\
\hline Listrik & 0,486 & 0,723 & 1,138 & 1,813 & 2,837 & 4,357 & 6,569 & 9,724 \\
\hline $\begin{array}{l}\text { Gas Bumi } \\
\text { Minyak } \\
\text { Tanah }\end{array}$ & 0,004 & 0,006 & 0,009 & 0,014 & 0,022 & 0,034 & 0,051 & 0,076 \\
\hline $\begin{array}{l}\text { Minyak Solar } \\
\text { LPG }\end{array}$ & 0,043 & 0,065 & 0,102 & 0,162 & 0,253 & 0,389 & 0,587 & 0,868 \\
\hline \begin{tabular}{l} 
Total \\
\hline
\end{tabular} & 0,012 & 0,018 & 0,123 & 0,196 & 0,306 & 0,470 & 0,709 & 1,049 \\
\hline
\end{tabular}


Proyeksi pada sektor komersial skala nasional diperkirakan meningkat sebesar $6,5 \%$ per tahun dengan penggunaan listrik tumbuh sebesar $6,6 \%$ per tahun. Pada beberaoa gedung juga menggunakan minyak diesel sebagai bahan bakar genset. Pada gambar 4.19 ditunjukkan konsumsi energi sektor komersial.

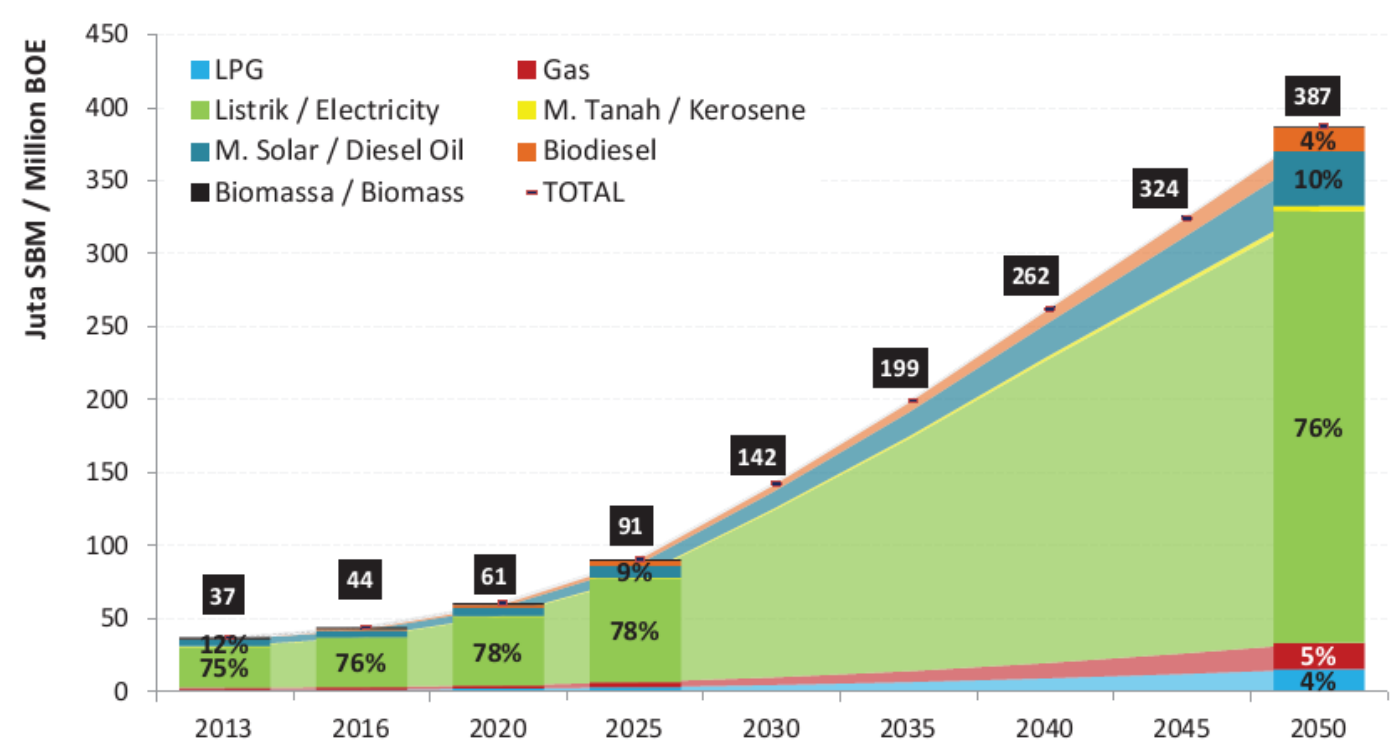

Gambar 4.19 Konsumsi Energi Sektor Komersial Nasional

Sumber : (Sugiyono et al., 2014)

\subsubsection{Konsumsi Energi Sektor Lain}

Pada sektor ini terdiri dari pertambangan, konstruksi, dan pertanian yang merupakan sektor energi yang mengindikasikan pertumbuhan secara fisik seperti pada konstruksi pembangunan gedung-gedung baru atau bangunan sipil. Sub sektor pertambangan adalah usaha ekplorasi yang dilakukan perusahaan atau pemerintah setempat seperti pada pertambangan nikel yang merupakan komuditas utama Sulawesi Selatan. Sub sektor pertanian merupakan lapangan usaha yang 
$43 \%$ penduduk Sulawesi Selatan menggeluti pekerjaan tersebut. Pada gambar 4.20 ditunjukkan proyeksi pengguna energi pada sektor lain.

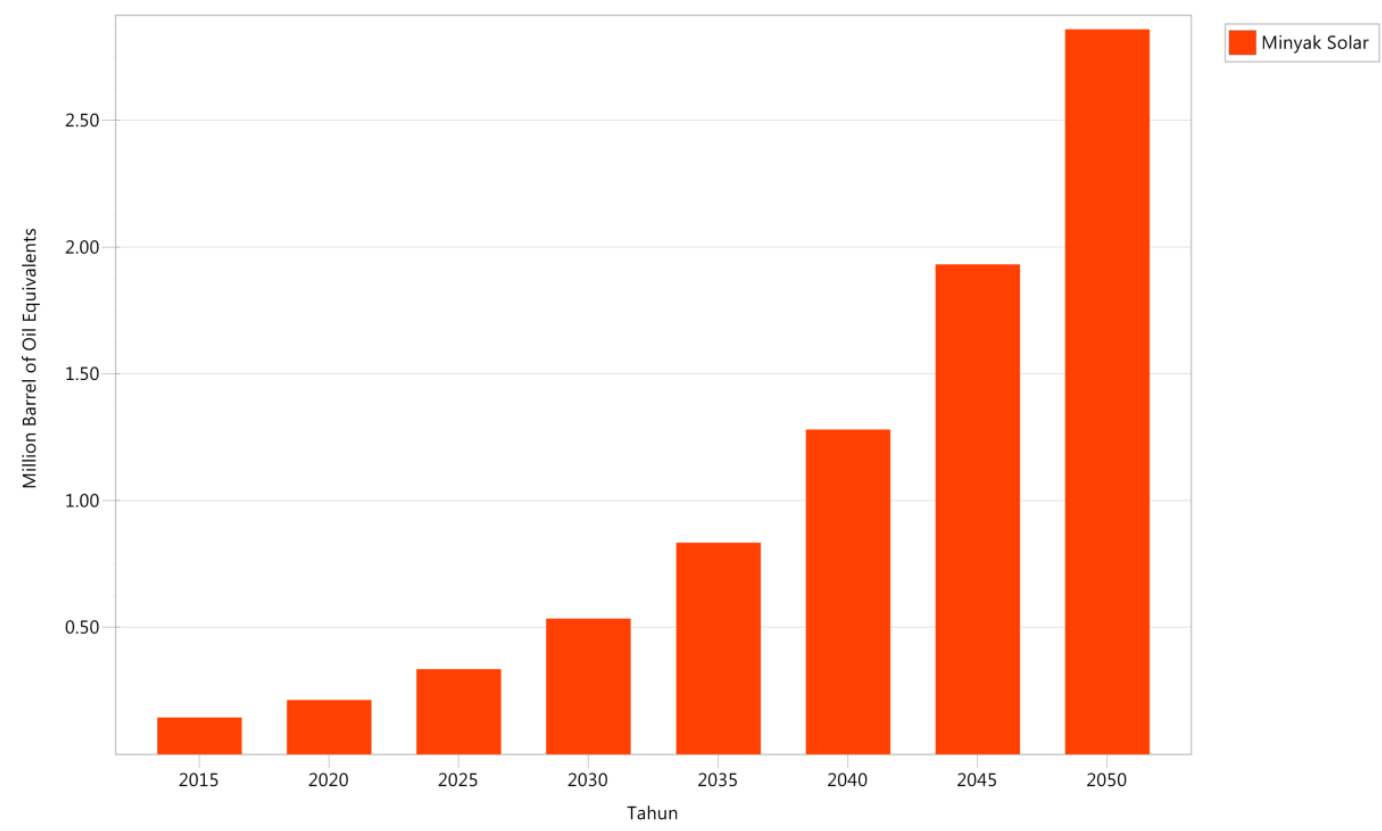

Gambar 4.20 Konsumsi Energi Sektor Lain

Pada gambar 4.20 penggunaan energi jenis minyak solar merupakan konsumsi terbesar untuk sektor ini. Minyak solar adalah bahan bakar yang digunakan untuk menggerakkan mesin-mesin pada kegiatan konstruksi dan mesin traktor pada kegiatana pertanian. Pada sektor pertambangan memiliki mesinmesin yang digunakan untuk ekplorasi. Pada Pada tabel 4.10 ditunjukkan mengenai detail konsumsi energi pada sektor lain.

Tabel 4.10 Konsumsi Energi Jenis Sektor Lain

\begin{tabular}{|l|c|c|c|c|c|c|c|c|}
\hline \multirow{2}{*}{ Jenis Energi } & \multicolumn{7}{|c|}{ Tahun ( Juta SBM ) } \\
\cline { 2 - 9 } & 2015 & 2020 & 2025 & 2030 & 2035 & 2040 & 2045 & 2050 \\
\hline $\begin{array}{l}\text { Minyak } \\
\text { Solar }\end{array}$ & 0,143 & 0,212 & 0,334 & 0,533 & 0,833 & 1,280 & 1,930 & 2,857 \\
\hline \begin{tabular}{l} 
Total \\
\hline
\end{tabular} & 0,143 & 0,212 & 0,334 & 0,533 & 0,833 & 1,280 & 1,930 & 2,857 \\
\hline
\end{tabular}


Proyeksi kebutuhan energi sektor lain pada skala nasional mencakup kegiatan pertanian, perikanan, konstruksi bangunan dan properti serta kegiatan pertambangan. Kegiatan-kegiatan tersebut menggunakan sumber energi minyak solar sebagai bahan bakar, sehingga dalam sektor ini pemanfaatan minyak solar meningkat laju 6,5\% per tahun. Pada gambar 4.21 ditunjukkan konsumsi energi sektor lain.

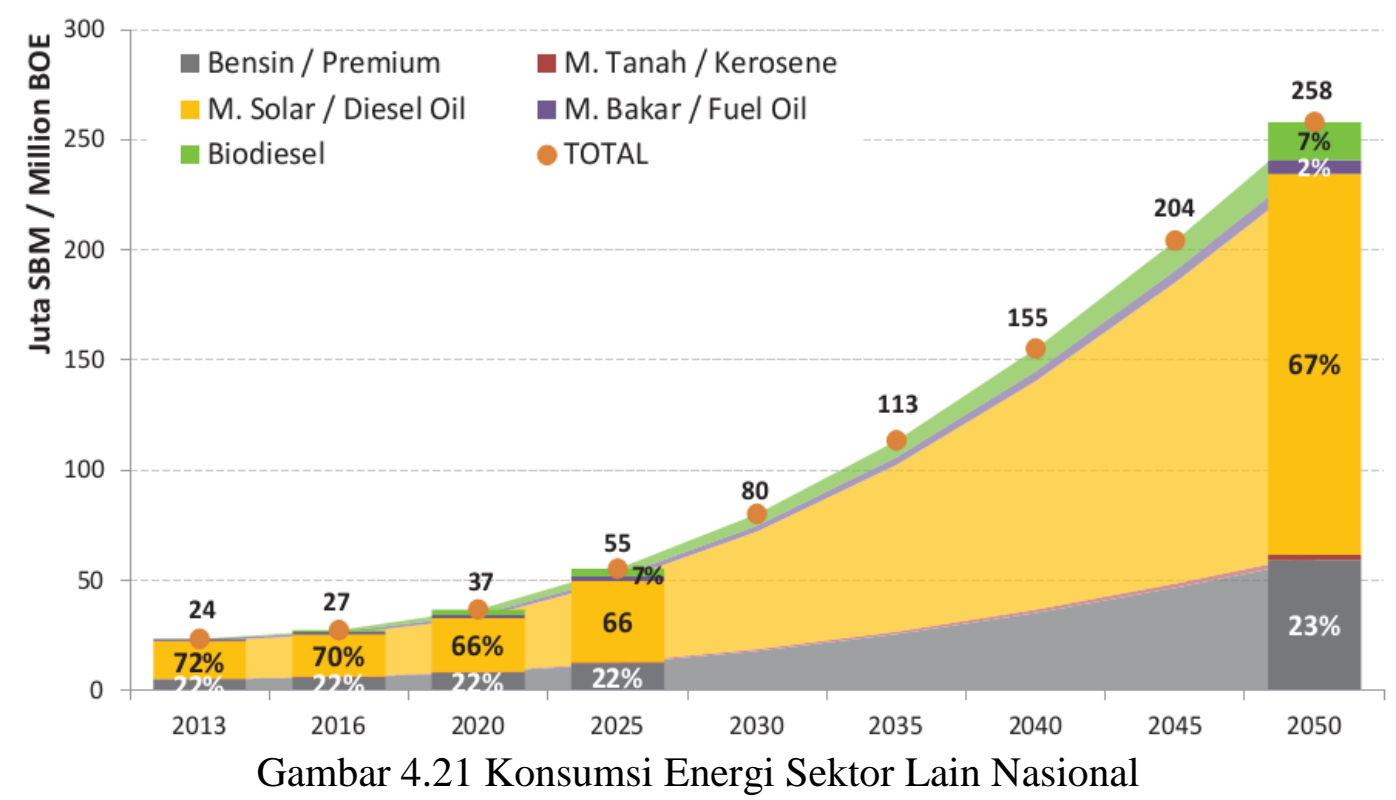

Sumber :(Sugiyono et al., 2014)

\subsection{Proyeksi Penyediaan Energi}

\subsubsection{Pembangkit Listrik}

Pada sektor penyediaan tenaga listrik PT. PLN (Persero) dan perusahaan swasta lainnya memiliki rencana pembangunan tenaga listrik yang berkelanjutan sesuai dengan RUPTL. Pada gambar 4.22 ditunjukkan peta kondisi penyediaan energi listrik di Sulawesi selatan. 


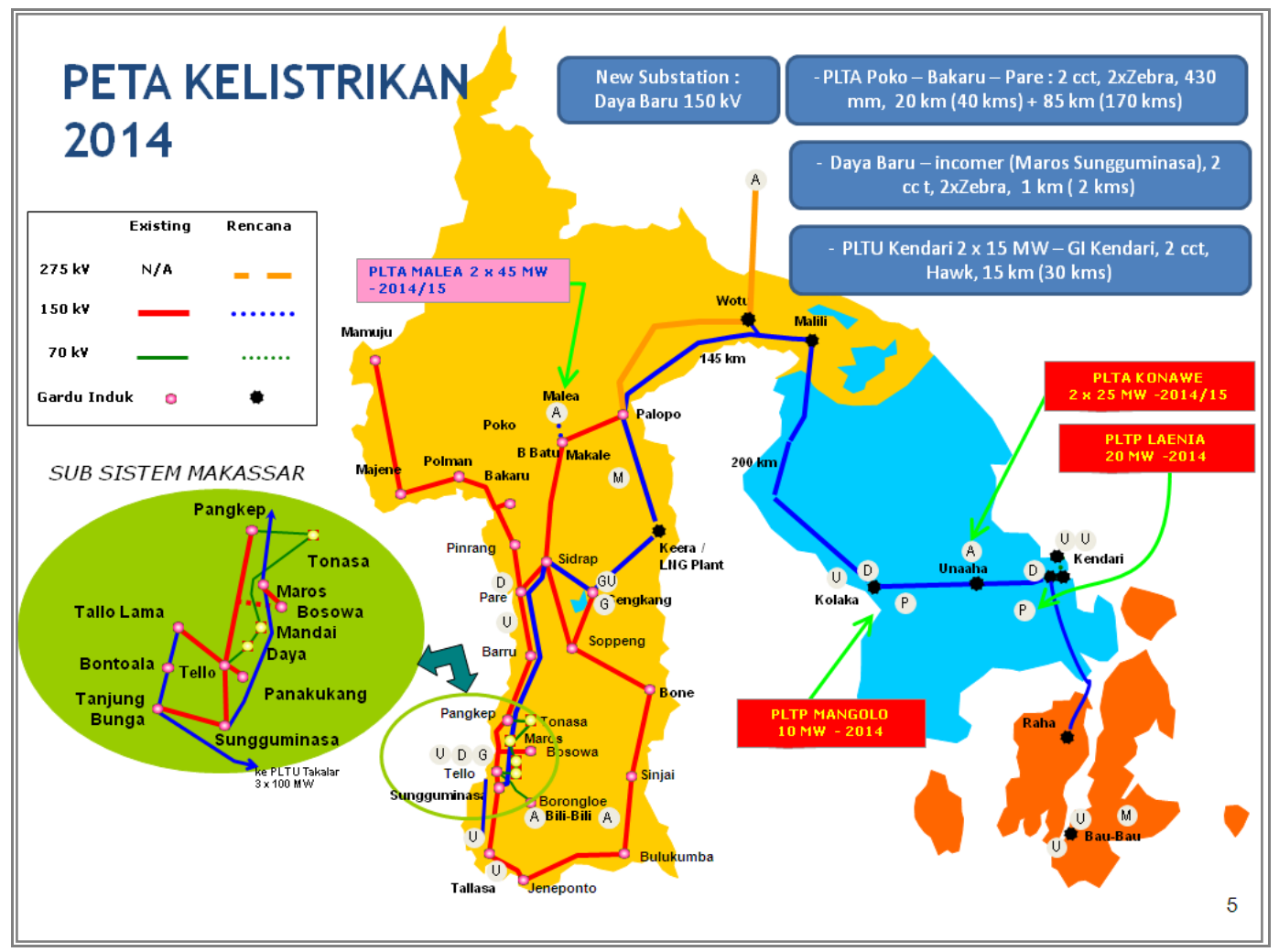

Gambar 4.22 Peta kelistrikan Sulawesi Selatan

Sumber:Rencana Umum Ketenagalistrikan Daerah (RUKD) Propinsi Sulawesi Selatan, 2003

Pada gambar tersebut memberikan gamrbaran mengenai perkembangan pembangkit energi listrik di Sulawesi selatan. Pada proyeksi menggunakan skenario $\mathrm{BaU}$ pembangkit listrik yang disesuaikan dengan rancangan KEN menghasilkan bauran energi listrik yang didominasi oleh energi fosil dan air. Pada gambar 4.23 ditunjukkan proyeksi pembangkit listrik skenario $\mathrm{BaU}$ 


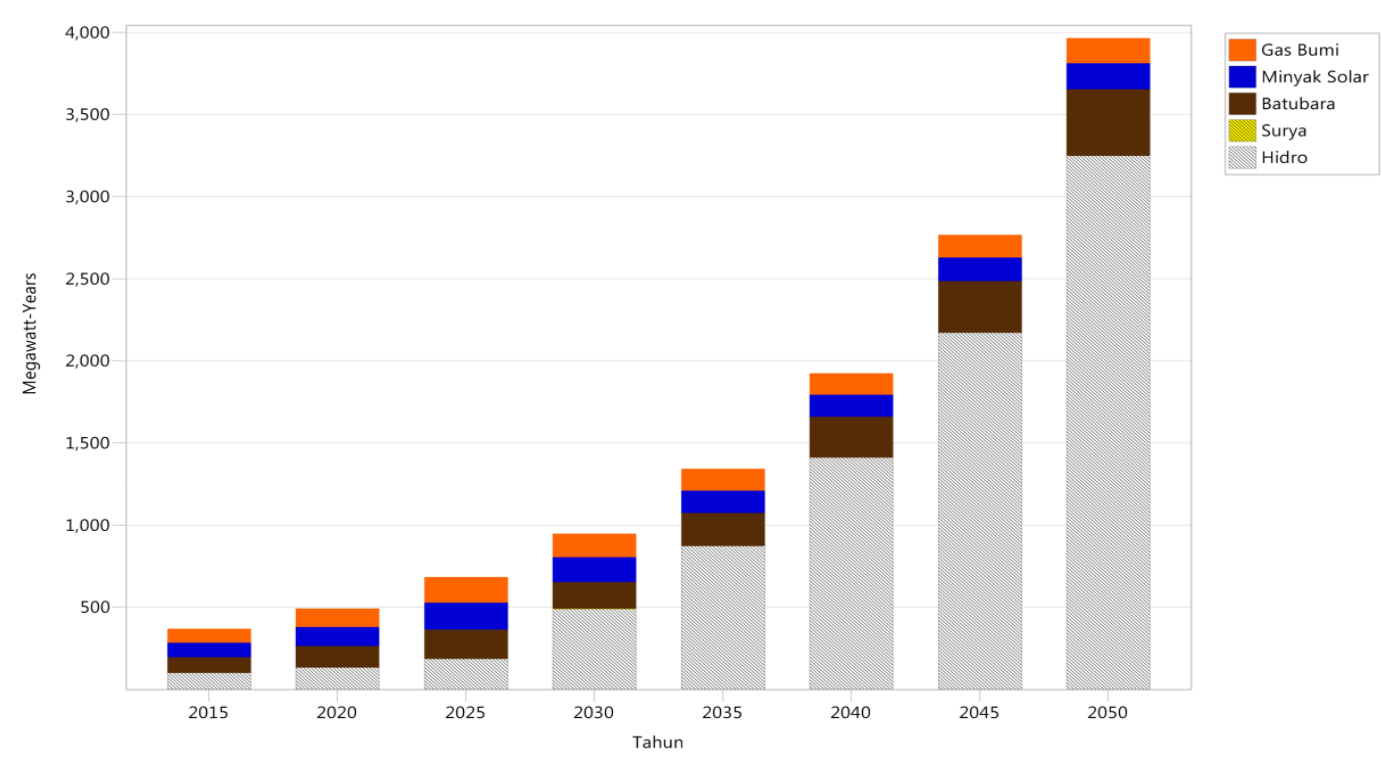

Gambar 4.23 Proyeksi pembangkit listrik skenario $\mathrm{BaU}$

Penggunaan energi air merupakan sumber utama dalam pembangkitan energi listrik. Sumber energi lain seperti batu bara dan gas bumi merupakan jenis energi yang dikembangkan untuk tiap pembangkit baru yang ada di Sulawesi selatan. Pada tabel 4.11 ditunjukkan mengenai proyeksi jenis energi yang digunakan pada pembangkit listrik.

Tabel 4.11 Proyeksi Energi Jenis Sektor Pembangkit Skenario BaU

\begin{tabular}{|l|c|c|c|c|c|r|r|r|}
\hline \multirow{2}{*}{ Sumber Energi } & \multicolumn{7}{|c|}{ Tahun (Juta MWh) } \\
\cline { 2 - 10 } & 2015 & 2020 & 2025 & 2030 & 2035 & 2040 & 2045 & 2050 \\
\hline \multirow{2}{*}{ Gas Bumi } & 0,723 & 0,968 & 1,344 & 1,240 & 1,135 & 1,120 & 1,185 & 1,309 \\
\hline Minyak Solar & 0,765 & 1,023 & 1,422 & 1,311 & 1,200 & 1,184 & 1,254 & 1,384 \\
\hline Batubara & 0,843 & 1,128 & 1,567 & 1,445 & 1,765 & 2,175 & 2,764 & 3,561 \\
\hline & 0,001 & 0,001 & 0,002 & 0,002 & 0,002 & 0,002 & 0,002 & 0,002 \\
\hline Surya & 0,879 & 1,177 & 1,635 & 4,286 & 7,644 & 12,365 & 19,022 & 28,454 \\
\hline Hidro & 3,211 & 4,297 & 5,970 & 8,284 & 11,746 & 16,846 & 24,227 & 34,711 \\
\hline \multirow{2}{*}{ Total } & & & & & & & & \\
\hline
\end{tabular}


Pada tabel 4.11 bahan bakar fosil seperti batu bara, minyak solar, dan gas alam mengalamai penurunan kapasitas daya pada tahun 2050. Penurunan daya disebabkan oleh seiring berkurangnya atau langkanya sumber bahan baku energi fosil tersebut. Sumber energi terbarukan surya mengalami penurunan juga disebabkan pembangkit yang tersebar di seluruh wilayah Sulawesi selatan dan pemeliharaan pembangkit ini kurang dilirik oleh pemerintah setempat karena harga yang mahal serta suku cadang untuk perbaikan yang masih langka.

Pada skenario CE diasumsikan menggunakan RUPTL dan penetrasi untuk bauran energi terbarukan dan bersih lebih besar yaitu dengan adanya pembangunan pembangkit listrik angin, panas bumi, dan biomassa di Sulawesi Selatan. Energi Angin saat ini direncanakan dibangun di dua kabupaten. Bioenergi seperti biomassa telah dibangun dengan sumber energi yang berasal dari sekam padi atau pun tandan kelapa sawit. Pada gambar 4.24 ditunjukkan proyeksi pembangkit listrik skenario CE. 


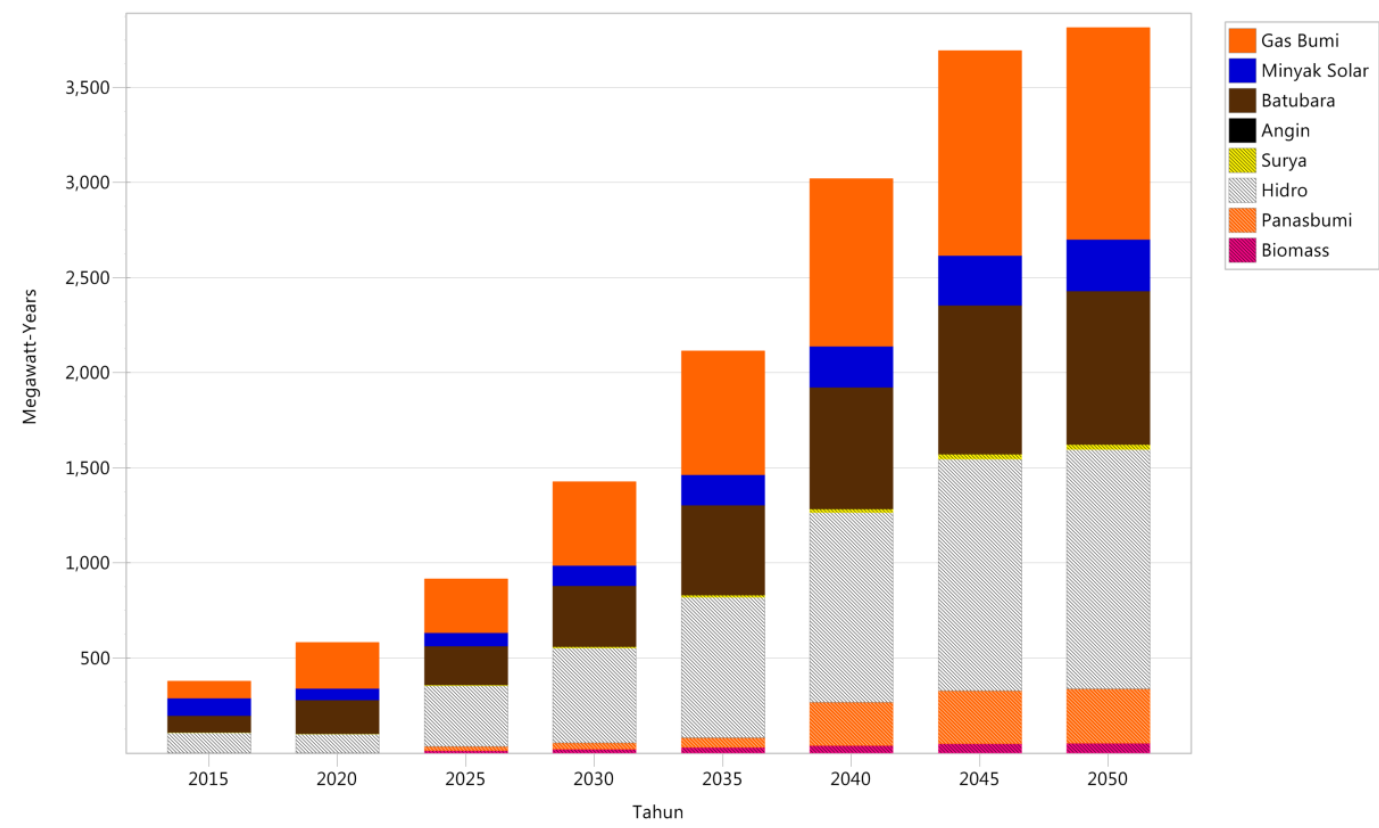

Gambar 4.24 Proyeksi pembangkit listrik skenario CE

Pada gambar diatas panas bumi, angin, dan biomassa memberikan bauran energi terbarukan yang lebih banyak dibanding energi surya. Pada tabel 4.12 ditunjukkan mengenai proyeksi jenis energi yang digunakan pada pembangkit listrik skenario CE

Tabel 4.12 Proyeksi Jenis Energi Sektor Pembangkit Skenario CE

\begin{tabular}{|l|r|r|r|r|r|r|r|r|}
\hline \multicolumn{1}{|c|}{$\begin{array}{c}\text { Sumber } \\
\text { Energi }\end{array}$} & 2015 & 2020 & 2025 & 2030 & 2035 & 2040 & 2045 & 2050 \\
\cline { 2 - 10 } \\
\hline Gas Bumi & 0,774 & 2,125 & 2,477 & 3,857 & 5,712 & 7,715 & 9,439 & 9,744 \\
\hline Minyak Solar & 0,818 & 0,522 & 0,606 & 0,944 & 1,397 & 1,887 & 2,309 & 2,383 \\
\hline Batubara & 0,767 & 1,550 & 1,798 & 2,800 & 4,147 & 5,601 & 6,853 & 7,074 \\
\hline Angin & 0,000 & 0,000 & 0,000 & 0,000 & 0,000 & 0,001 & 0,001 & 0,001 \\
\hline Surya & 0,004 & 0,012 & 0,024 & 0,055 & 0,106 & 0,176 & 0,216 & 0,223 \\
\hline Hidro & 0,941 & 0,880 & 2,806 & 4,369 & 6,470 & 8,738 & 10,691 & 11,035 \\
\hline
\end{tabular}


Tabel 4.12 Proyeksi Jenis Energi Sektor Pembangkit Skenario CE (lanjutan)

\begin{tabular}{|c|c|c|c|c|c|c|c|c|}
\hline \multirow{2}{*}{$\begin{array}{l}\text { Sumber } \\
\text { Energi }\end{array}$} & \multicolumn{8}{|c|}{ Tahun ( Juta MWh) } \\
\hline & 2015 & 2020 & 2025 & 2030 & 2035 & 2040 & 2045 & 2050 \\
\hline Panasbumi & - & - & 0,189 & 0,295 & 0,437 & 1,987 & 2,431 & 2,509 \\
\hline Biomass & - & - & 0,111 & 0,173 & 0,257 & 0,347 & 0,424 & 0,438 \\
\hline Total & 3,304 & 5,088 & 8,012 & 12,493 & 18,525 & 26,453 & 32,363 & 33,407 \\
\hline
\end{tabular}

Pada tabel 4.24 Pembangkit listrik skenario CE menghasilkan energi lebih besar 49 MW dibanding pembangkit listrik skenario BaU pada tahun 2050. Pada tahun 2025 pembangkit listrik pada skenario CE dan BaU memiliki kapasitas total yang sama karena pada tahun tersebut pembangkit berdasarkan RUPTL belum terlaksana secara penuh.

Pada skenario CE menggunakan kebijakan target 35.000 MW pemerintah Indonesia yang disesuaikan dengan Kepmen 0074.K/21/MEM/2015. Proyek pemerintah Indonesia dengan peningkatan pertumbuhan ekonomi sebesar $7 \%$ setiap tahunnya maka dibutuhkan listrik sebesar 7000 MW setiap tahun. Proyek ini dibagi ke dalam dua bagian yaitu :

1. Pengembangan listrik swasta 25.904 MW

2. PT. PLN (Persero) 10.681 MW.

Kebijakan pemerintah Nasioanal mempengaruhi kebijakan pemerintah regional pula seperti pada pemerintah provinsi Sulawesi Selatan. Setiap pembangunan pembangkit listrik melalui dua sistem pengadaan yang jelaskan sebelumnya telah melalui sistem pelelangan terhadap kebijakan energi di daerah 
masing-masing baik pembangkit yang bersifat terbarukan maupun non-terbarukan atau fosil.

Pada proyeksi pembangkit listrik nasional dari 25 TWh tahun 2013 menjadi 418 TWh tahun 2050. Pembangkit listrik EBT diprediksi tumbuh sebesar $8 \%$ pertahun dengan bauran energi yang paling besar berasal dari PLTP dan PLTA. Pada gambar 4.25 ditunjukkan produksi listrik berdasarkan jenis pembangkit.

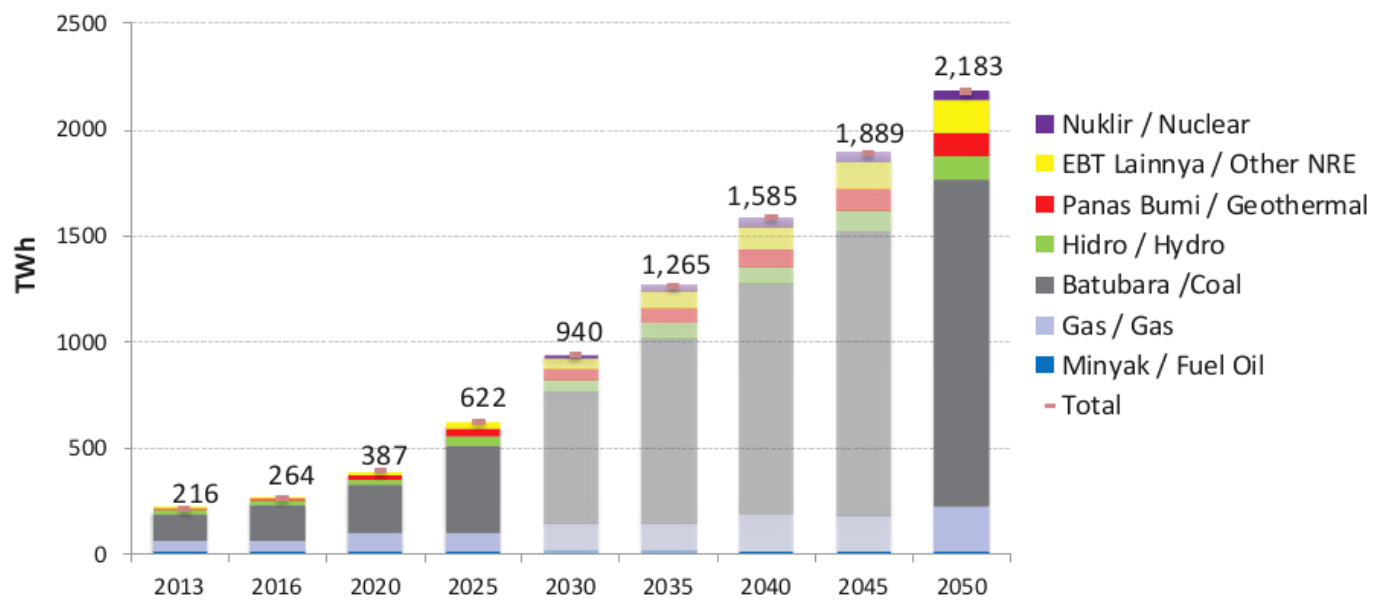

Gambar 4.25 Proyeksi Produksi Listrik Nasional

Sumber : (Sugiyono et al., 2014)

\subsubsection{Tambang Gas Bumi}

Tambang gas bumi diproyeksikan untuk memenuhi kebutuhan ekspor dunia. Gas bumi ini berupa Liquid Natural Gas (LNG) dengan kapasitas 0,5 x 4 MTPA atau setara dengan 109,6186 Giga Joule per tahun. Pada Skenario BaU produksi setiap tahun selalu sama, sedangkan pada skenario CE produksi LNG meningkat 5\% setiap tahunnya. Pada gambar 4.26 ditunjukkan proyeksi kilang LNG skenario CE. 


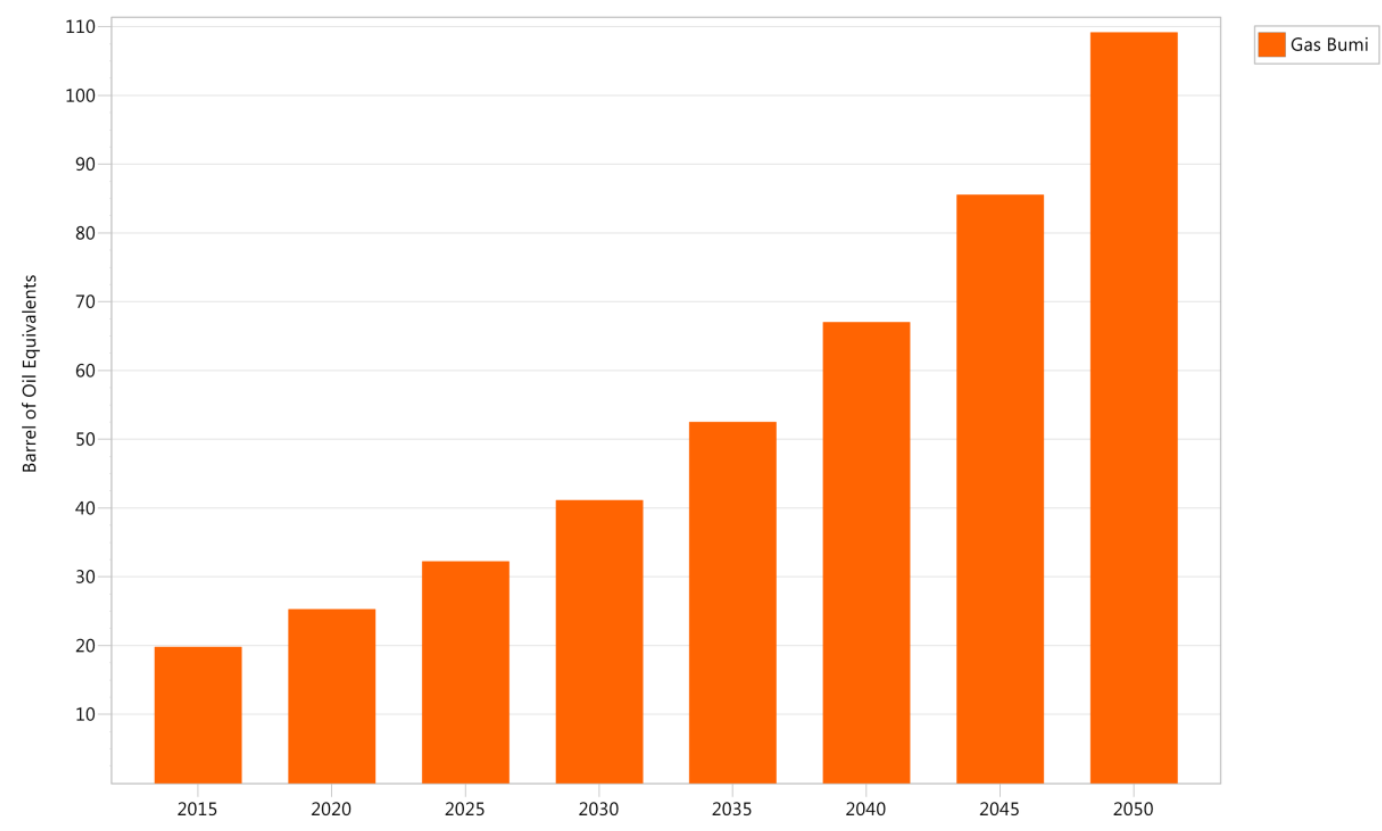

Gambar 4.26 Produksi Kilang LNG Skenario CE

Gas bumi di Sulawesi selatan saat ini dikelola oleh PT Energy Sengkang tepatnya di kabupaten wajo. Gas bumi yang diproduksi digunakan untuk keperluan ekspor. Pada tabel 4.13 ditunjukkan proyeksi pertumbuhan pada kilang LNG.

Tabel 4.13 Produksi LNG Skenario CE

\begin{tabular}{|c|c|c|c|c|c|c|c|c|}
\hline \multirow{2}{*}{ Jenis Energi } & \multicolumn{7}{|c|}{ Tahun ( SBM ) } \\
\cline { 2 - 10 } & 2015 & 2020 & 2025 & 2030 & 2035 & 2040 & 2045 & 2050 \\
\hline \multirow{2}{*}{ Gas Bumi } & 19,795 & 25,263 & 32,243 & 41,152 & 52,521 & 67,031 & 85,551 & 109,187 \\
\hline Total & 19,795 & 25,263 & 32,243 & 41,152 & 52,521 & 67,031 & 85,551 & 109,187 \\
\hline
\end{tabular}

Pada skala nasional pangsa terbesar pemanfaatan gas adalah untuk sektor industri mencapai $44 \%$ dari total pemanfaatan gas dan akan meningkat pada tahun 2050 menjadi 69\%. Gas bumi di sektor industri selai untuk bahan bakar juga digunakan sebagai bahan baku. Pada tahun 2050 sektor pembangkit listrik, 
komersial dan transportasi masing-masing menggunakan sebesar 26\%, 13\%, dan 1\%. Sektor rumah tangga menggunakan sebesar 1\%. Pada gambar 4.27 ditunjukkan penggunaan sektor pada setiap sektor.

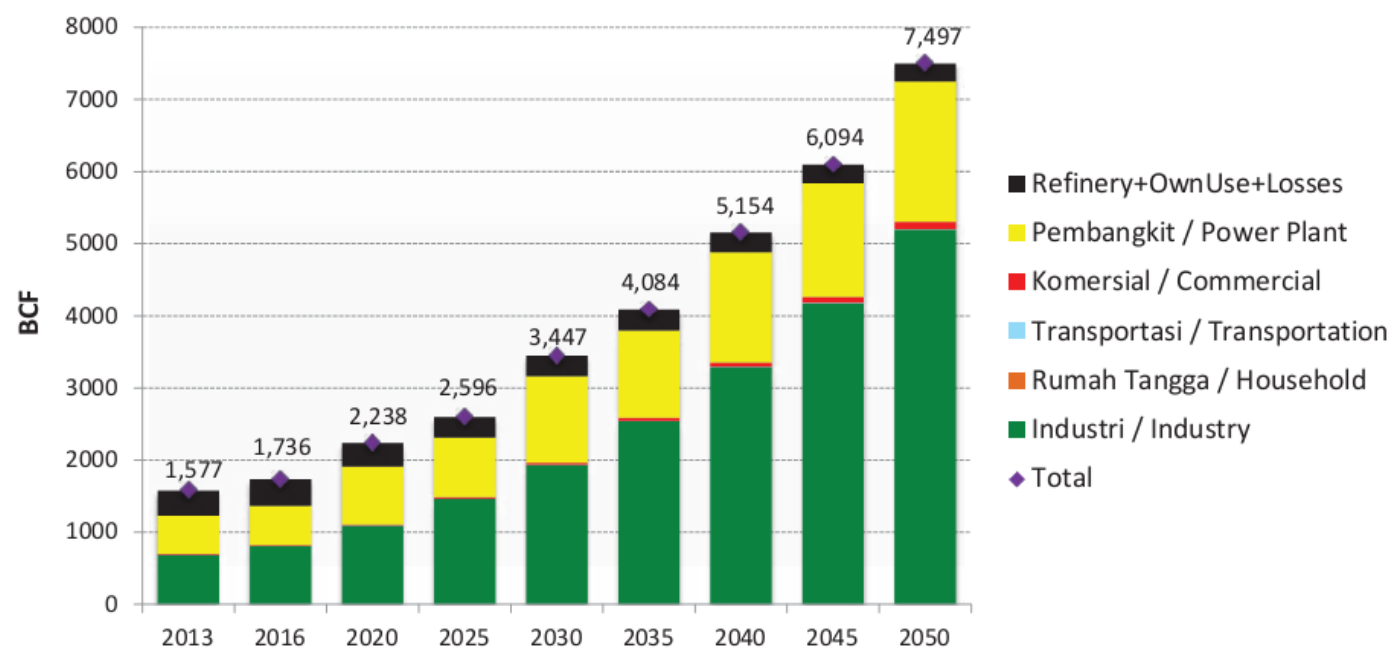

Gambar 4.27 Proyeksi Pemakaian Gas Pada Setiap Sektor

Sumber : (Sugiyono et al., 2014)

\subsection{Neraca Energi}

Neraca energi adalah gambaran keseimbangan antara pasokan berbagai sumber energi dan penggunaan energi dalam periode tertentu (UU Nomor 30/2007 tentang Energi). Dari hasil analisa tentang kebutuhan energi dan penyediaan energi di Sulawesi selatan menunjukkan bahwa untuk sumber energi fosil Sulawesi Selatan masih mengimpor seperti batu bara 2.029.846,54 SBM, minyak tanah 279.429,96 SBM, minyak solar 3.499.146,84, minyak bakar 128.631,95 SBM, dan premium 5.617.558,67 SBM. Pada tabel 4.14 ditunjukkan neraca energi Sulawesi selatan pada tahun 2014 skenario BaU. 
Tabel 4.14 Neraca Energi Sulawesi Selatan Tahun 2014 Skenario BaU

\begin{tabular}{|c|c|c|c|c|c|c|c|c|c|c|c|c|c|c|}
\hline Sektor & Listrik & Gas Bumi & Premium & Avtur & Minyak Tanah & Minyak Solar & Minyak Bakar & LPG & Batubara & Surya & Hidro & LNG & Non BBM & Total \\
\hline Production & - & $2,314,802.00$ & - & - & - & - & 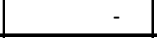 & - & - & 0.12 & $563,339.39$ & - & 5 & $2,878,141.52$ \\
\hline Imports & - & $2,607,890.15$ & 5,617,558.67 & $2,067,506.28$ & $287,656.76$ & $3,443,946.68$ & $128,631.95$ & \begin{tabular}{|l|}
$1,443,273.33$ \\
\end{tabular} & $1,985,502.32$ & $2,340.73$ & - & - & 0.03 & \begin{tabular}{|l|}
$17,584,306.91$ \\
\end{tabular} \\
\hline Exports & -0.00 & $-2,199,061.90$ & - & - & - & & & - & - & - & - & -18.85 & & $-2,199,080.75$ \\
\hline Total Primary Supply & -0.00 & $2,723,630.25$ & $5,617,558.67$ & $2,067,506.28$ & $287,656.76$ & $3,443,946.68$ & $128,631.95$ & $1,443,273.33$ & $1,985,502.32$ & $2,340.86$ & $563,339.39$ & -18.85 & 0.03 & $18,263,367.67$ \\
\hline Pabrik Biogas & - & - & - & - & - & - & - & - & - & - & - & - & - & - \\
\hline Produksi Biomass & - & - & - & - & - & - & - & - & - & - & - & - & - & - \\
\hline Tambang Batubara & - & - & - & - & - & - & - & - & - & - & - & - & - & - \\
\hline Tambang Gas Bumi & - & $-115,740.10$ & - & - & - & - & - & - & - & - & - & - & - & $-115,740.10$ \\
\hline Tambang Minyak Bumi & - & - & - & - & - & - & - & - & - & - & - & - & - & - \\
\hline Pencairan Batubara & - & - & - & - & - & - & - & - & - & - & - & - & - & - \\
\hline Pabrik Briket & - & - & - & - & - & - & - & - & - & - & - & - & - & - \\
\hline Pabrik Bioetanol & - & - & - & - & - & - & - & - & - & - & - & - & - & - \\
\hline \begin{tabular}{|l|} 
Pabrik Biodiesel \\
\end{tabular} & - & - & - & - & - & - & - & - & - & - & - & - & - & - \\
\hline Regasifikasi LNG & - & - & - & - & - & - & - & - & - & - & - & - & - & - \\
\hline Kilang LPG & - & - & - & - & - & - & - & - & - & - & - & - & - & - \\
\hline Kilang LNG & - & -22.18 & - & - & - & - & - & - & - & - & - & 18.85 & - & -3.33 \\
\hline Pembangkit Listrik & 1,976,441.61 & $-1,133,879.08$ & - & - & - & $-1,633,076.58$ & - & - & $-1,311,907.82$ & $-2,340.86$ & $-563,339.39$ & - & - & $-2,668,102.12$ \\
\hline Transmisi Distribusi & $-237,172.99$ & - & - & - & - & - & - & - & - & - & - & - & - & $-237,172.99$ \\
\hline Total Transformation & $1,739,268.62$ & $-1,249,641.36$ & - & - & - & $\begin{array}{r}-1,633,076.58 \\
\end{array}$ & - & - & $-1,311,907.82$ & $-2,340.86$ & \begin{tabular}{|c|}
$-563,339.39$ \\
\end{tabular} & 18.85 & - & $-3,021,018.54$ \\
\hline Rumah Tangga & $821,067.70$ & $1,469,085.97$ & - & - & $223,348.01$ & - & - & \begin{tabular}{|l|}
$1,427,046.76$ \\
\end{tabular} & - & - & - & - & - & $3,940,548.44$ \\
\hline Industri & $357,917.14$ & - & 646.37 & - & 260.10 & $15,793.71$ & $3,248.35$ & - & $673,594.49$ & - & - & - & 0.03 & $1,051,460.20$ \\
\hline Transportasi & - & - & $5,616,912.29$ & \begin{tabular}{|l|}
$2,067,506.28$ \\
\end{tabular} & - & $1,591,062.16$ & $125,383.60$ & - & - & - & - & - & - & $9,400,864.34$ \\
\hline Komersial & $560,283.78$ & $4,902.92$ & - & - & $64,048.65$ & $71,169.16$ & - & $16,226.57$ & - & - & - & - & - & $716,631.09$ \\
\hline Khusus & - & - & - & - & - & - & - & - & - & - & - & - & - & - \\
\hline Lainnya & - & - & - & - & - & $132,845.07$ & - & - & - & - & - & - & - & $132,845.07$ \\
\hline Total Demand & $1,739,268.62$ & $1,473,988.89$ & $5,617,558.67$ & $2,067,506.28$ & $287,656.76$ & $1,810,870.10$ & $128,631.95$ & $1,443,273.33$ & $673,594.49$ & - & - & - & 0.03 & $15,242,349.13$ \\
\hline
\end{tabular}

Satuan Energi : Setara Barel Minyak (SBM) 


\subsection{Bauran Energi Tahun 2025 dan 2050}

Dari hasil analisis neraca energi dapat disederhanakan untuk bauran energi terbagi atas empat sumber yaitu :

1. Minyak Bumi;

2. Gas Bumi;

3. Batu Bara;

4. Energi Terbarukan.

Pada Tabel 4.15 ditunjukkan perbandingan bauran energi yang telah dicapai antara skenario $\mathrm{BaU}$ dan $\mathrm{CE}$. Bauran energi terbarukan dapat membantu mengatasi krisis energi dan meningkatkan ketahanan energi.

Tabel 4.15 Bauran Energi Sulawesi Selatan

\begin{tabular}{|c|l|c|c|l|l|l|}
\hline \multirow{2}{*}{ No } & \multirow{2}{*}{ Jenis Bauran } & \multirow{2}{*}{ Tahun } & \multicolumn{2}{|c|}{ Skenario BaU } & \multicolumn{2}{|c|}{ Skenario CE } \\
\cline { 4 - 7 } & Energi & 2014 & Tahun & Tahun & Tahun & Tahun \\
& & & 2025 & 2050 & 2025 & 2050 \\
\hline 1 & Minyak Bumi & $71.12 \%$ & $68.33 \%$ & $66.01 \%$ & $55.03 \%$ & $55.47 \%$ \\
\hline 2 & Gas Bumi & $14.91 \%$ & $12.69 \%$ & $3.36 \%$ & $15.31 \%$ & $9.88 \%$ \\
\hline 3 & Batu Bara & $10.87 \%$ & $14.49 \%$ & $16.13 \%$ & $15.09 \%$ & $18.67 \%$ \\
\hline 4 & Energi & $3.10 \%$ & $4.49 \%$ & $14.50 \%$ & $14.57 \%$ & $15.98 \%$ \\
\hline
\end{tabular}

Pada tabel diatas ditunjukkan bauran energi baru terbarukan akan lebih cepat karena pada tahun 2050 skenario BaU sebesar $14.50 \%$ sedangkan pada 
tahun 2025 skenario CE sebesar 14.57\%. Skenario CE lebih cepat 25 tahun untuk meningkatkan bauran energi yang sama pada skenario $\mathrm{BaU}$.

\subsection{Sekuritas Energi}

Untuk menghitung energy security yang menjadi indikator Tingkat Ketergantungan Impor (TKI) sebagai parameter utama ketahanan energi. Kaitan antara Energy Security dan Tingkat Ketergantungan Terhadap Impor (TKI) Energi ditunjukkan dalam rumus sebagai berikut:

$$
\mathrm{ES}=1-\mathrm{TKI}
$$

Dimana

$$
\mathrm{ES}=\text { Energy Security }
$$

$\mathrm{TKI}=($ net impor energi $) /($ konsumsi energi $)$.

Net impor energi diperoleh dari selisih antara impor dan ekspor, sedangkan konsumsi energi dipeorleh dari penjumlahan energi final di sektor demand dengan energi untuk pembangkit listrik. Nilai Energy Security berkisar antar $0-100 \%$ atau $0-1$. Angka 1 menunjukkan bahwa sebuah daerah tidak perlu melakukan ekspor untuk memenuhi kebutuhannya. Sedangkan angka 0 menunjukkan bahwa sebuah daerah perlu mengimpor energi untuk memenuhi kebutuhannya. Pada tabel 4.16 ditunjukkan ketahanan energi antara skenario BaU dan CE. 
Tabel 4.16 Perbandingan Energy Security skenario BaU dan CE

\begin{tabular}{|l|c|c|c|c|c|}
\hline \multirow{2}{*}{\multicolumn{1}{|c|}{ Indikator }} & \multirow{2}{*}{ Tahun } & \multicolumn{2}{c|}{ BaU } & \multicolumn{2}{c|}{ CE } \\
\cline { 3 - 6 } & 2014 & 2025 & 2050 & 2025 & 2050 \\
\hline Energy Security & $14.10 \%$ & $9.14 \%$ & $5.78 \%$ & $10.94 \%$ & $3.06 \%$ \\
\hline Tingkat & $85.90 \%$ & $90.86 \%$ & $94.35 \%$ & $89.06 \%$ & $96.94 \%$ \\
Ketergantungan Impor & & & & & \\
\hline Net Impor Enegi & 14,94 & 27,51 & 118,86 & 28,16 & 151,38 \\
(Juta SBM) & & & & & \\
\hline Konsumsi Energi & 17,47 & 30,28 & 126,16 & 31,61 & 156,159 \\
\hline \multirow{2}{*}{ (Juta SBM) } & & & & & \\
\hline
\end{tabular}




\section{BAB V}

\section{KESIMPULAN DAN SARAN}

\subsection{Kesimpulan}

1. Proyeksi kebutuhan energi Sulawesi Selatan pada tahun 2025 pada sektor rumah tangga adalah 6,310 Juta SBM, industri 2,647 Juta SBM, transportasi 15,931 Juta SBM, komersial 1,4 Juta SBM, dan sektor lainnya 0,334 Juta SBM. Jadi total kebutuhan energi skenario BaU pada tahun 2014 adalah 26,62 Juta SBM, dan pada tahun 2050 adalah 136,343 juta SBM dengan detail sektor rumah tangga 20,426 juta SBM, industri 22,611 juta SBM, trasnportasi 78,493 juta SBM, komersial 11,956 juta SBM, dan lain-lainnya 2,857

2. Bauran energi di Sulawesi selatan didominasi oleh minyak bumi pada tahun 2025 dengan menggunakan skenario sistem energi bersih sebesar 55,03\%, gas bumi 15,31\%, dan Batu bara 15,09\%. Pada tahun 2050 kebutuhan minyak bumi akan meningkat dan gas bumi akan menurung yaitu 55,47\% dan 9,88\%. Sedangkan untuk batu bara akan semakin meningkat dengan cadangan yang masih melimpah yang diimpor dari Kalimantan yaitu 18,67\%.

3. Energi baru/terbarukan (EBT) dapat memberi bauran energi sebesar $14,57 \%$ pada tahun 2025 dan $15,98 \%$ pada tahun 2050 menggunakan skenario sistem energi bersih (CE). Sedangkan dengan skenario BaU pada tahun 2025 sebesar 4,49\% dan tahun 2050 sebesar $14,50 \%$

4. Ketahanan energi pada tahun 2025 pada skenario BaU adalah 9,14\% dan pada tahun 2050 adalah 5,78\%. Sedangka pada skenario CE pada tahun 2025 adalah 10,94\% dan pada tahun $20503,06 \%$. 


\subsection{Saran}

1. Seharusnya penggunaan energi terbarukan sangat dibutuhkan untuk mengurangi dampak krisis energi di masa yang akan datang.

2. Melakukan usaha pengumpulan data tentang energi secara terpusat untuk menentukan kevalidan dan keakuratan proyeksi energi.

3. Meningkatkan upaya hemat energi pada sektor rumah tangga dan industri dan meningkatkan penggunaan energi terbarukan dengan menggunakan PV pada atap bangunan.

4. Mengoptimalkan pembangunan pembangkit listrik dengan sumber energi jenis air agar dapat meningkatkan bauran energi daerah atau pun nasional. 


\section{DAFTAR PUSTAKA}

BPS Sulawesi Selatan. (2014). Statistik Daerah Provinsi Sulawesi Selatan 2014. Badan Pusat Statistik Provinsi Sulawesi Selatan.

ESDM Sulawesi Selatan. (2014). Potensi Energi Terbarukan dan Pemanfaatan di Sulawesi Selatan. Makassar.

Connolly, D., Lund, H., Mathiesen, B. V., \& Leahy, M. (2010). A review of computer tools for analysing the integration of renewable energy into various energy systems. Applied Energy, 87(4), 1059-1082. http://doi.org/10.1016/j.apenergy.2009.09.026

Elinur, Priyarsono, D. S., Tambunan, M., \& Firdaus, M. (2010). PERKEMBANGAN KONSUMSI DAN PENYEDIAAN ENERGI DALAM PEREKONOMIAN INDONESIA. Indonesian Journal of Agricultural Econmics (IJAE), 2.

Haryono, E., \& Dr. Eng. Deendarlianto, S. (2014). ANALISIS KESEIMBANGAN ENERGI DAERAH ISTIMEWA YOGYAKARTA. Universitas Gadjah Mada. Retrieved from http://etd.repository.ugm.ac.id/index.php?mod=penelitian_detail\&sub=Pen elitianDetail\&act=view\&typ=html\&buku_id=69064\&obyek_id=4

Heaps, C. (2012). Long-range Energy Alternatives Planning (LEAP) system (Version [Software version 2015.0.6]). Somerville, MA, USA: Stockholm Environment Institute. Retrieved from http://energycommunity.org/default.asp?action=171

Huang, Y., Bor, Y. J., \& Peng, C.-Y. (2011). The long-term forecast of Taiwan's energy supply and demand: LEAP model application. Energy Policy, 39(11), 6790-6803. http://doi.org/10.1016/j.enpol.2010.10.023

Kale, R. V., \& Pohekar, S. D. (2014). Electricity demand and supply scenarios for Maharashtra (India) for 2030: An application of long range energy alternatives planning. Energy Policy, 72, 1-13. http://doi.org/10.1016/j.enpol.2014.05.007 
Manjang, S., Arief, M., \& Kitta, I. (2013). OPTIMALISASI PENGGUNAAN ENERGI TERBARUKAN LOKAL SEBAGAI ENERGI PRIMER PEMBANGKIT TENAGA LISTRIK DI SULAWESI SELATAN BERBASIS SKENARIO ENERGI MIX NASIONAL. Retrieved from http://repository.unhas.ac.id/handle/123456789/9804

McPherson, M., \& Karney, B. (2014). Long-term scenario alternatives and their implications: LEAP model application of Panama's electricity sector. Energy Policy, 68, 146-157. http://doi.org/10.1016/j.enpol.2014.01.028

MIT Clean Energy Prize | Sponsored by Eversource Energy. (n.d.). Retrieved 8 September 2015, from http://cep.mit.edu/structure/categories

Mondal, M. A. H., Boie, W., \& Denich, M. (2010). Future demand scenarios of Bangladesh power sector. Energy Policy, 38(11), 7416-7426. http://doi.org/10.1016/j.enpol.2010.08.017

Nurmawati, T. (2009). Potensi Energi Biomassa Dari Limbah Pertanian di Propinsi Sulawesi Selatan. Tangerang: B2TE BPPT.

PLN. (2014). Rencana Usaha Penyediaan Tenaga Listrik (RUPTL) Tahun 2015 2014. Jakarta: PT PLN (Persero).

Prasad, R. D., Bansal, R. C., \& Raturi, A. (2014). Multi-faceted energy planning: A review. Renewable and Sustainable Energy Reviews, 38, 686-699. http://doi.org/10.1016/j.rser.2014.07.021

Putra, C. P., Tuegeh, M., Tumaliang, H., \& Patras, L. S. (2014). Analisa Pertumbuhan Beban Terhadap Ketersediaan Energi Listrik di Sistem Kelistrikan Sulawesi Selatan. JURNAL TEKNIK ELEKTRO DAN KOMPUTER UNSRAT, 3(2), 19-30.

Rencana Umum Ketenagalistrikan Daerah (RUKD) Propinsi Sulawesi Selatan. (2003). Tim Kajian Pengembangan Energi dan RUKD, Propinsi Sulawesi Selatan.

Roinioti, A., Koroneos, C., \& Wangensteen, I. (2012). Modeling the Greek energy system: Scenarios of clean energy use and their implications. Energy Policy, 50, 711-722. http://doi.org/10.1016/j.enpol.2012.08.017 
Saddler, H., Diesendorf, M., \& Denniss, R. (2007). Clean energy scenarios for Australia. Energy Policy, 35(2), 1245-1256. http://doi.org/10.1016/j.enpol.2006.03.013

Sahrul. (2015, April 3). Pertamina - Harga Minyak Mentah Dunia Melorot, Jangan Panik! Retrieved February 23, 2016, from http://www.pertamina.com/news-room/seputar-energi/harga-minyakmentah-dunia-melorot,-jangan-panik!/

Sri Lestari. (2015, August 19). Konsumsi Avtur Garuda Indonesia Setahun Capai 1,7 Miliar Liter - Kompas.com. Retrieved February 19, 2016, from http://bisniskeuangan.kompas.com/read/2015/08/19/132640726/Konsumsi .Avtur.Garuda.Indonesia.Setahun.Capai.1.7.Miliar.Liter

Suganthi, L., \& Samuel, A. A. (2012). Energy models for demand forecasting - A review. Renewable and Sustainable Energy Reviews, 16(2), 1223-1240.

Sugiyono, A., Anindhita, F., Boedoyo, M. S., \& Adiarso (Eds.). (2014). Outlook Energi Indonesia 2014. Jakarta: PTPSE-BPPT.

Sugiyono, A., \& Boedoyo, M. S. (1999). Perubahan Pola Penggunaan Energi dan Perencanaan Penyediaan Energi. Hasil-Hasil Lokakarya Energy Nasional $\mathrm{Ke}-17$.

Suyuti, A. (2011). Potensi energi matahari di Sulawesi Selatan Berbasis Perhitungan RETScreen International. Retrieved from http://repository.unhas.ac.id/handle/123456789/2601

The National Energy Council. (2015). Executive Reference Data 2015. Jakarta.

Tim Kajian Pengembangan Energi, \& ESDM. (2003). Rencana Umun Ketenagalistrikan Daerah. Makassar: ESDM Sulawesi Selatan.

Vicharus Dianjiwa. (2015, August 5). 2015, Tahun Jebloknya Industri Batu Bara. Retrieved February 23, 2016, from http://www.tambang.co.id/7179-7179/

Yi, H. (2015). Clean-energy policies and electricity sector carbon emissions in the U.S. states. Utilities Policy, 34, 19-29. 


\section{LAMPIRAN}


Lampiran 1 Pemakaian Bahan Bakar Gas (BBG)

\begin{tabular}{|c|c|c|c|c|c|c|c|c|c|c|c|c|c|c|c|c|c|}
\hline Kemasan & Ukuran & Sifat & Region & Sales District & JAN 2014 & FEB 2014 & MAR 2014 & APR 2014 & MAY 2014 & JUN 2014 & JUL 2014 & AUG 2014 & SEP 2014 & оCT 2014 & NOV 2014 & DEC 2014 & Grand Total \\
\hline PSO & $3 \mathrm{KG}$ & PSO & Sulawesi Selatan & Kab. Bantaeng & $216.72 \mathrm{MT}$ & $211.68 \mathrm{MT}$ & $238.56 \mathrm{MT}$ & $248.64 \mathrm{MT}$ & $267.12 \mathrm{MT}$ & $272.16 \mathrm{MT}$ & $332.64 \mathrm{MT}$ & $322.56 \mathrm{MT}$ & $297.36 \mathrm{MT}$ & $317.52 \mathrm{MT}$ & $263.76 \mathrm{MT}$ & $290.64 \mathrm{MT}$ & $3,279.36 \mathrm{MT}$ \\
\hline NPSO & $12 \mathrm{KG}$ & NPSO & Sulawesi Selatan & Kab. Bantaeng & $75.60 \mathrm{MT}$ & $69.12 \mathrm{MT}$ & $73.44 \mathrm{MT}$ & $75.60 \mathrm{MT}$ & $77.76 \mathrm{MT}$ & $84.24 \mathrm{MT}$ & 101.52 MT & $95.04 \mathrm{MT}$ & $71.28 \mathrm{MT}$ & $82.08 \mathrm{MT}$ & $64.80 \mathrm{MT}$ & $69.12 \mathrm{MT}$ & $939.60 \mathrm{MT}$ \\
\hline PSO & $3 \mathrm{KG}$ & Pso & lawesi Selatan & Kab. Barru & $332.64 \mathrm{MT}$ & 309.12 MT & $336.00 \mathrm{MT}$ & $336.00 \mathrm{MT}$ & $344.40 \mathrm{MT}$ & $341.04 \mathrm{MT}$ & $381.36 \mathrm{MT}$ & $386.40 \mathrm{MT}$ & 408.24 MT & $445.20 \mathrm{MT}$ & $359.52 \mathrm{MT}$ & $398.16 \mathrm{MT}$ & $4,378.08 \mathrm{MT}$ \\
\hline NPSO & $12 \mathrm{KG}$ & NPSO & awesi Sel & Kab. Barru & $35.64 \mathrm{MT}$ & 40.68 MT & 36.67 MT & $44.35 \mathrm{MT}$ & $51.17 \mathrm{MT}$ & $57.98 \mathrm{MT}$ & $66.05 \mathrm{MT}$ & $64.42 \mathrm{MT}$ & $47.90 \mathrm{MT}$ & $59.62 \mathrm{MT}$ & $48.77 \mathrm{MT}$ & $74 \mathrm{MT}$ & 597.98 MT \\
\hline $\begin{array}{l}\text { PSO } \\
\text { NPO }\end{array}$ & $3 \mathrm{KG}$ & PSO & awesi Selatan & Kab. Bone & $791.28 \mathrm{MT}$ & $757.68 \mathrm{MT}$ & 796.32 MT & $809.76 \mathrm{MT}$ & $824.88 \mathrm{MT}$ & $871.92 \mathrm{MT}$ & $935.76 \mathrm{MT}$ & $949.20 \mathrm{MT}$ & $959.28 \mathrm{MT}$ & 1,001.28 MT & 897.12 MT & $940.80 \mathrm{MT}$ & 10,535.28 MT \\
\hline $\begin{array}{l}\text { NPSO } \\
\text { PSO }\end{array}$ & $12 \mathrm{KG}$ & NPSO & wesi Selatan & Kab. Bone & $\begin{array}{l}73.20 \mathrm{MT} \\
\end{array}$ & $\begin{array}{r}75.22 \mathrm{MT} \\
\end{array}$ & $77.04 \mathrm{MT}$ & $81.50 \mathrm{MT}$ & $75.74 \mathrm{MT}$ & $75.89 \mathrm{MT}$ & $79.92 \mathrm{MT}$ & $90.72 \mathrm{MT}$ & $71.28 \mathrm{MT}$ & $84.24 \mathrm{MT}$ & $66.96 \mathrm{MT}$ & $69.12 \mathrm{MT}$ & $920.83 \mathrm{MT}$ \\
\hline $\begin{array}{l}\text { PSO } \\
\text { NPSO }\end{array}$ & 3 KG & $\begin{array}{l}\text { PSO } \\
\text { PPSO }\end{array}$ & $\begin{array}{l}\text { awesi Selatan } \\
\text { awesi Seltanta }\end{array}$ & kiumba & $636.72 \mathrm{MT}$ & $582.96 \mathrm{MT}$ & $606.48 \mathrm{MT}$ & $613.20 \mathrm{MT}$ & $633.36 \mathrm{MT}$ & $635.04 \mathrm{MT}$ & $749.28 \mathrm{MT}$ & $732.48 \mathrm{MT}$ & $696.60 \mathrm{MT}$ & $744.24 \mathrm{MT}$ & $613.20 \mathrm{MT}$ & 670.32 MT & $88 \mathrm{MT}$ \\
\hline $\begin{array}{l}\text { NPSO } \\
\text { NPSO }\end{array}$ & $\begin{array}{l}12 \mathrm{KG} \\
50 \mathrm{KG}\end{array}$ & $\begin{array}{l}\text { NPSO } \\
\text { NPSO }\end{array}$ & $\begin{array}{l}\text { Sulawess Selatan } \\
\text { Sulawesi Selatan }\end{array}$ & $\begin{array}{l}\text { Kab. Bulukumba } \\
\text { Kab. Bulukumba }\end{array}$ & 109.54 MT & $128.38 \mathrm{MT}$ & $127.44 \mathrm{MT}$ & $114.60 \mathrm{MT}$ & $116.64 \mathrm{MT}$ & 133.92 MT & 153.36 MT & $162.00 \mathrm{MT}$ & $105.84 \mathrm{MT}$ & 108.00 MT & $90.72 \mathrm{MT}$ & $\begin{array}{r}97.20 \mathrm{MT} \\
0.10 \mathrm{MT}\end{array}$ & $\begin{array}{r}1,447.63 \mathrm{MT} \\
0.10 \mathrm{MT}\end{array}$ \\
\hline PSO & 3 KG & PSO & Sulawesi Selatan & Kab. Enrekang & 263.76 MT & $230.16 \mathrm{MT}$ & $258.72 \mathrm{MT}$ & $260.40 \mathrm{MT}$ & $277.20 \mathrm{MT}$ & $267.12 \mathrm{MT}$ & $302.40 \mathrm{MT}$ & $294.00 \mathrm{MT}$ & $290.64 \mathrm{MT}$ & $307.44 \mathrm{MT}$ & 282.24 MT & $305.76 \mathrm{MT}$ & 3,339.84 MT \\
\hline עnso & $12 \mathrm{KG}$ & NPSO & Sulawesi Selatan & Kab. Enrekang & $40.46 \mathrm{MT}$ & $40.75 \mathrm{MT}$ & $37.54 \mathrm{MT}$ & $32.88 \mathrm{MT}$ & $42.48 \mathrm{MT}$ & $49.44 \mathrm{MT}$ & $49.20 \mathrm{MT}$ & $60.48 \mathrm{MT}$ & $47.28 \mathrm{MT}$ & $47.04 \mathrm{MT}$ & $35.04 \mathrm{MT}$ & $32.64 \mathrm{MT}$ & $515.23 \mathrm{MT}$ \\
\hline PSO & $3 \mathrm{KG}$ & PSO & Sulawesi Selatan & Kab. Gowa & 1,273.44 MT & 1,160.88 MT & 1,184.40 MT & 1,167.60 MT & 1,207.92 MT & 1,179.36 MT & 1,368.00 MT & 1,254.96 MT & 1,266.72 MT & 1,344.00 MT & 1,199.52 MT & $1,281.84 \mathrm{MT}$ & 14,888.64 MT \\
\hline NPSO & $12 \mathrm{KG}$ & NPSO & Sulawesi Selatan & Kab. Gowa & $216.43 \mathrm{MT}$ & 194.69 MT & $206.78 \mathrm{MT}$ & 207.36 MT & $220.32 \mathrm{MT}$ & 216.00 MT & $228.96 \mathrm{MT}$ & 220.32 MT & 185.76 MT & $190.08 \mathrm{MT}$ & $157.68 \mathrm{MT}$ & $157.68 \mathrm{MT}$ & $2,402.06 \mathrm{MT}$ \\
\hline NPSO & $12 \mathrm{KG}$ & BRIGHT GAS & awesi Selatan & Kab. Gowa & & & & & & & & & & $8.64 \mathrm{MT}$ & $4.32 \mathrm{MT}$ & $8.64 \mathrm{MT}$ & $21.60 \mathrm{MT}$ \\
\hline NPSO & 50 KG & NPSO & Sulawesi Selatan & Kab. Gowa & 24.25 MT & $21.75 \mathrm{MT}$ & 17.25 MT & 20.90 MT & 20.25 MT & $21.00 \mathrm{MT}$ & 10.25 MT & $23.65 \mathrm{MT}$ & $23.75 \mathrm{MT}$ & $21.50 \mathrm{MT}$ & 21.50 MT & $28.65 \mathrm{MT}$ & $254.70 \mathrm{MT}$ \\
\hline PsO & 3 KG & PSO & awesi Selatan & Kab. Jeneponto & $384.72 \mathrm{MT}$ & $369.60 \mathrm{MT}$ & $393.60 \mathrm{MT}$ & $428.40 \mathrm{MT}$ & $451.92 \mathrm{MT}$ & 460.32 MT & $515.76 \mathrm{MT}$ & $512.40 \mathrm{MT}$ & $506.76 \mathrm{MT}$ & $556.08 \mathrm{MT}$ & 477.12 MT & $520.80 \mathrm{MT}$ & 5,577.48 MT \\
\hline Pso & $3 \mathrm{KG}$ & PSO & dlawesi Selatan & Kab. Luwu & 425.04 MT & $386.40 \mathrm{MT}$ & $416.64 \mathrm{MT}$ & 425.04 MT & $445.20 \mathrm{MT}$ & 453.60 MT & 535.92 MT & $519.12 \mathrm{MT}$ & 497.28 MT & 529.20 MT & 472.08 MT & 507.36 MT & $5,612.88 \mathrm{MT}$ \\
\hline NPSO & $12 \mathrm{KG}$ & NPSO & lawesi Selatan & Kab. Luwu & $67.30 \mathrm{MT}$ & $107.30 \mathrm{MT}$ & $107.54 \mathrm{MT}$ & 109.56 MT & $126.36 \mathrm{MT}$ & $115.08 \mathrm{MT}$ & $132.60 \mathrm{MT}$ & $122.64 \mathrm{MT}$ & $96.58 \mathrm{MT}$ & $75.36 \mathrm{MT}$ & $51.60 \mathrm{MT}$ & $56.52 \mathrm{MT}$ & $1,168.44 \mathrm{MT}$ \\
\hline NPSO & 50 KG & NPSO & Sulawesi Selatan & Kab. Luwu & & $1.00 \mathrm{MT}$ & $1.00 \mathrm{MT}$ & $0.50 \mathrm{MT}$ & $0.25 \mathrm{MT}$ & $0.50 \mathrm{MT}$ & $0.25 \mathrm{MT}$ & $0.25 \mathrm{MT}$ & $0.25 \mathrm{MT}$ & & & & $4.00 \mathrm{MT}$ \\
\hline PSO & $3 \mathrm{KG}$ & Pso & awesi Selatan & Kab. Luwu Timur & $334.32 \mathrm{MT}$ & $330.96 \mathrm{MT}$ & $364.56 \mathrm{MT}$ & $361.20 \mathrm{MT}$ & $388.08 \mathrm{MT}$ & $388.08 \mathrm{MT}$ & 451.92 MT & $411.60 \mathrm{MT}$ & 414.96 MT & 463.68 MT & 421.68 MT & 462.00 MT & 4,793.04 MT \\
\hline NPSO & $12 \mathrm{KG}$ & NPSO & lawesi Selatan & Kab. Luwu Timur & $12.24 \mathrm{MT}$ & $12.24 \mathrm{MT}$ & $12.24 \mathrm{MT}$ & $12.24 \mathrm{MT}$ & $12.24 \mathrm{MT}$ & $18.36 \mathrm{MT}$ & $12.24 \mathrm{MT}$ & 18.36 MT & $12.24 \mathrm{MT}$ & $12.24 \mathrm{MT}$ & & $12.24 \mathrm{MT}$ & 146.88 MT \\
\hline NPsO & $50 \mathrm{KG}$ & NPSO & lawesi Selatan & Kab. Luwu Timur & $0.25 \mathrm{MT}$ & & & & $0.25 \mathrm{MT}$ & & & & & & & $0.25 \mathrm{MT}$ & $0.75 \mathrm{MT}$ \\
\hline Pso & $3 \mathrm{KG}$ & PSO & Sulawesi Selatan & Kab. Luwu Utara & $371.52 \mathrm{MT}$ & $340.20 \mathrm{MT}$ & $381.48 \mathrm{MT}$ & $371.40 \mathrm{MT}$ & $370.80 \mathrm{MT}$ & 414.48 MT & $450.84 \mathrm{MT}$ & 441.36 MT & 432.96 MT & 474.36 MT & $424.08 \mathrm{MT}$ & $50.96 \mathrm{MT}$ & 24.44 MT \\
\hline $\begin{array}{l}\text { PSO } \\
\text { INPSO }\end{array}$ & $3 \mathrm{KG}$ & $\begin{array}{l}\text { PSO } \\
\text { PSOS }\end{array}$ & $\begin{array}{l}\text { Sulawesi Selatan } \\
\text { pulawes Selat }\end{array}$ & Kab. Maros & $626.04 \mathrm{MT}$ & $567.24 \mathrm{MT}$ & $603.12 \mathrm{MT}$ & $606.48 \mathrm{MT}$ & $631.68 \mathrm{MT}$ & $624.96 \mathrm{MT}$ & 712.32 MT & $672.00 \mathrm{~N}$ & $687.12 \mathrm{MT}$ & 747.60 & $660.24 \mathrm{MT}$ & $668.64 \mathrm{~N}$ & \\
\hline $\begin{array}{l}\text { Pso } \\
\text { pso }\end{array}$ & $12 \mathrm{KG}$ & NPSO & Sulawesi Selatan & Kab. Maros & $51.70 \mathrm{MT}$ & $4.32 \mathrm{MT}$ & & & & & & & & & & & иT \\
\hline & $50 \mathrm{KG}$ & NPSO & Sulawesi Selatan & Kab. Maros & & & & & & & & & & & & & $0.25 \mathrm{MT}$ \\
\hline so & 3 KG & PSO & Sulawesi Selatan & Kab. Pangkep & $638.40 \mathrm{MT}$ & $542.64 \mathrm{MT}$ & 564.48 MT & $566.16 \mathrm{MT}$ & $16.56 \mathrm{MT}$ & $519.92 \mathrm{MT}$ & $693.84 \mathrm{MT}$ & $656.88 \mathrm{MT}$ & $613.20 \mathrm{MT}$ & 714.00 MT & $584.64 \mathrm{MT}$ & $677.04 \mathrm{MT}$ & $487.76 \mathrm{MT}$ \\
\hline IPSO & $12 \mathrm{~K}$ & NPSO & awesi Selatan & b. Pangkep & $112.90 \mathrm{MT}$ & $129.02 \mathrm{MT}$ & $110.88 \mathrm{MT}$ & $116.93 \mathrm{MT}$ & $100.80 \mathrm{MT}$ & $118.94 \mathrm{MT}$ & $114.91 \mathrm{MT}$ & $120.96 \mathrm{MT}$ & $90.72 \mathrm{MT}$ & $90.72 \mathrm{MT}$ & $80.64 \mathrm{MT}$ & $74.59 \mathrm{MT}$ & $1,262.02 \mathrm{MT}$ \\
\hline NPso & $50 \mathrm{r}$ & NPSO & awesi Selatan & b. Pangkep & $13.75 \mathrm{MT}$ & $5.50 \mathrm{MT}$ & $8.25 \mathrm{MT}$ & $2.75 \mathrm{MT}$ & $2.75 \mathrm{MT}$ & $5.50 \mathrm{MT}$ & $2.75 \mathrm{MT}$ & $5.50 \mathrm{MT}$ & $2.75 \mathrm{MT}$ & $5.50 \mathrm{MT}$ & $5.50 \mathrm{MT}$ & $5.50 \mathrm{MT}$ & $5.00 \mathrm{MT}$ \\
\hline PSo & $3 k$ & PSO & awesi Selatan & b. Pinrang & $614.88 \mathrm{MT}$ & $552.72 \mathrm{MT}$ & $598.08 \mathrm{MT}$ & $593.04 \mathrm{MT}$ & $630.00 \mathrm{MT}$ & $609.84 \mathrm{MT}$ & 702.24 MT & 702.24 MT & $680.40 \mathrm{MT}$ & $748.68 \mathrm{MT}$ & $636.72 \mathrm{MT}$ & $692.16 \mathrm{MT}$ & $7,761.00 \mathrm{MT}$ \\
\hline NPSO & 12 KG & NPS S & wesi Selatan & b. Pinrang & 124.99 MT & $120.24 \mathrm{MT}$ & $137.76 \mathrm{MT}$ & $142.08 \mathrm{MT}$ & $148.80 \mathrm{MT}$ & 148.32 MT & 172.80 MT & $166.08 \mathrm{MT}$ & $121.44 \mathrm{MT}$ & $121.92 \mathrm{MT}$ & $108.48 \mathrm{MT}$ & 4 MT & $1,624.75 \mathrm{MT}$ \\
\hline PsO & $3 k$ & PSO & awesi Selatan & b. Selayar & $87.36 \mathrm{MT}$ & $87.36 \mathrm{MT}$ & 107.52 MT & 102.48 MT & $110.88 \mathrm{MT}$ & 107.52 MT & 114.24 MT & $152.88 \mathrm{MT}$ & $131.04 \mathrm{MT}$ & $131.04 \mathrm{MT}$ & 114.24 MT & $115.92 \mathrm{MT}$ & $1,362.48 \mathrm{MT}$ \\
\hline PSO & $3 \mathrm{k}$ & PSO & Sulawesi Selatan & Kab. Sidrap & 627.24 MT & $562.44 \mathrm{MT}$ & $618.36 \mathrm{MT}$ & 602.64 MT & 632.28 MT & $613.20 \mathrm{MT}$ & 683.76 MT & 672.00 MT & 693.84 MT & $722.40 \mathrm{MT}$ & 603.12 MT & 663.60 MT & 7,694.88 MT \\
\hline NPSO & & NPSO & awesi Selatan & Kab.s & $47.52 \mathrm{MT}$ & $54.00 \mathrm{MT}$ & $58.32 \mathrm{MT}$ & $56.16 \mathrm{MT}$ & $54.00 \mathrm{MT}$ & $56.16 \mathrm{MT}$ & $62.64 \mathrm{MT}$ & $82.08 \mathrm{MT}$ & $56.16 \mathrm{MT}$ & $56.16 \mathrm{MT}$ & $49.68 \mathrm{MT}$ & $47.52 \mathrm{MT}$ & $680.40 \mathrm{MT}$ \\
\hline NPSO & 50 & NPS & awesi Selatan & . Sidrap & $0.45 \mathrm{MT}$ & & $1.05 \mathrm{MT}$ & $0.70 \mathrm{MT}$ & & $0.70 \mathrm{MT}$ & & & & $1.25 \mathrm{MT}$ & & $1.20 \mathrm{MT}$ & $5.35 \mathrm{MT}$ \\
\hline PSO & $3 \mathrm{KG}$ & PSC & Sulawesi Selatan & Kab.s & $238.56 \mathrm{MT}$ & 246.96 MT & 250.32 MT & $250.32 \mathrm{MT}$ & $267.12 \mathrm{MT}$ & $270.48 \mathrm{MT}$ & $312.48 \mathrm{MT}$ & 305.76 MT & $288.96 \mathrm{MT}$ & 312.4 & $280.56 \mathrm{MT}$ & $312.48 \mathrm{MT}$ & $3,336.48 \mathrm{MT}$ \\
\hline $\begin{array}{l}\text { NPsO } \\
\text { NPSO }\end{array}$ & $\begin{array}{l}12 \mathrm{~K} \\
50 \mathrm{~K} \\
\mathrm{~s}\end{array}$ & $\begin{array}{l}\text { NPSO } \\
\text { NSSO }\end{array}$ & $\begin{array}{l}\text { Sulawesi Selatan } \\
\text { Sulawesi Selatata }\end{array}$ & $\begin{array}{l}\text { Kab. Sinjai } \\
\text { Kab Siniai }\end{array}$ & 75.11 MT & $67.93 \mathrm{MT}$ & $69.59 \mathrm{MT}$ & $84.24 \mathrm{MT}$ & 79.92 MT & $88.56 \mathrm{MT}$ & 103.68 MT & 101.52 MT & $71.28 \mathrm{MT}$ & 101.09 MT & $81.65 \mathrm{MT}$ & $\begin{array}{l}83.81 \mathrm{MT} \\
0.02 \mathrm{MT}\end{array}$ & 1,008.37 MT \\
\hline & & {$\left[\begin{array}{l}\text { NPS } \\
\text { PSO }\end{array}\right.$} & $\begin{array}{l}\text { Sulawesi Selatan } \\
\text { Sulawess Selatatan }\end{array}$ & $\begin{array}{l}\text { Kab. Sinj } \\
\text { Kab Soo }\end{array}$ & & & & & & & & & & & & & \\
\hline $\begin{array}{l}\text { PSO } \\
\text { NPSO }\end{array}$ & $\begin{array}{l}3 \mathrm{KG} \\
12 \mathrm{KG}\end{array}$ & $\begin{array}{l}\text { PSO } \\
\text { NPSO }\end{array}$ & $\begin{array}{l}\text { Sulawess Selatan } \\
\text { Sulawesi Selatan }\end{array}$ & $\begin{array}{l}\text { Kab. Soppeng } \\
\text { Kab. Soppeng }\end{array}$ & $\begin{array}{r}r / 1.28 \mathrm{MI} \\
19.58 \mathrm{MT}\end{array}$ & $\begin{array}{r}444.40 \mathrm{MI} \\
19.58 \mathrm{MT}\end{array}$ & $\begin{array}{l}24.10 \mathrm{MT} \\
\end{array}$ & $19.20 \mathrm{MT}$ & $\begin{array}{l}20.00 \mathrm{MT} \\
24.00\end{array}$ & $21.60 \mathrm{MT}$ & $31.20 \mathrm{MT}$ & $28.80 \mathrm{MT}$ & $19.20 \mathrm{MT}$ & $\begin{array}{r}16.80 \mathrm{MT} \\
16.04\end{array}$ & $21.60 \mathrm{MT}$ & $\begin{array}{l}\begin{array}{r}425.04 \mathrm{MI} \\
14.40 \mathrm{MT}\end{array}\end{array}$ & 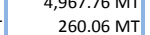 \\
\hline$e_{0}+2$ & $3 \mathrm{k}$ & PSO & Selatan & . T & $631.68 \mathrm{MT}$ & $544.32 \mathrm{MT}$ & $551.04 \mathrm{MT}$ & $564.48 \mathrm{MT}$ & $576.24 \mathrm{MT}$ & & $631.68 \mathrm{MT}$ & $596.40 \mathrm{MT}$ & & $658.56 \mathrm{MT}$ & 601.44 MT & $653.52 \mathrm{MT}$ & $7,165.20 \mathrm{MT}$ \\
\hline so & 12 & NPS & n & b. T. & 34.56 MT & 38.88 & & & & & & & & & & & \\
\hline NPSO & $50 \mathrm{r}$ & NPS & n & Kab. T & $2.50 \mathrm{MT}$ & $5.00 \mathrm{MT}$ & $5.00 \mathrm{MT}$ & ит & $7.50 \mathrm{MT}$ & MT & $5.00 \mathrm{MT}$ & ИT & & & MT & & $87.50 \mathrm{MT}$ \\
\hline PSO & $3 k$ & ps & n & raja & $179.76 \mathrm{MT}$ & 144.48 MT & 166.32 MT & 174.72 MT & $184.80 \mathrm{Y}$ & $169.68 \mathrm{MT}$ & $193.20 \mathrm{MT}$ & $210.00 \mathrm{MT}$ & $194.88 \mathrm{MT}$ & 201.60 MT & $183.12 \mathrm{MT}$ & 204.96 MT & $207.52 \mathrm{MT}$ \\
\hline NPSO & 12 & $\mathrm{NI}$ & ? & 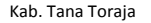 & $161.66 \mathrm{MT}$ & $126.26 \mathrm{MT}$ & $134.40 \mathrm{MT}$ & $128.40 \mathrm{MT}$ & $128.40 \mathrm{MT}$ & $126.00 \mathrm{MT}$ & $153.60 \mathrm{MT}$ & $147.60 \mathrm{MT}$ & $123.60 \mathrm{MT}$ & $122.40 \mathrm{MT}$ & $116.40 \mathrm{MT}$ & $135.60 \mathrm{MT}$ & 1,604.33 MT \\
\hline NPSO & & & ? & & $1.50 \mathrm{MT}$ & $3.75 \mathrm{MT}$ & $2.70 \mathrm{MT}$ & 3.3 & 3.3 & 3.3 & 3.3 & 4.5 & & ит & $3.30 \mathrm{MT}$ & 4. & $40.70 \mathrm{MT}$ \\
\hline PS & & Ps & 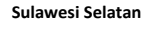 & ja Utara & $216.72 \mathrm{MT}$ & 193.20 MT & 208.32 MT & 199.92 MT & 215.0 & 213.3 & 228.4 & & 240.2 & $248.6-3$ & 236. & 272. & 2,709.84 MT \\
\hline ras & & pros & $n$ & & 596.40 MT & $530.88 \mathrm{MT}$ & $577.92 \mathrm{MT}$ & 571.20 MT & 599. & 577. & & & & & & & 7,369.56 MT \\
\hline & & & & & 79.7 & & & & & & & & & & & & $958.58 \mathrm{MT}$ \\
\hline PSO & & Ps & si & & 3,593.64 MT & 3,387.36 MT & & & & & & & & & & & $43,863.84 \mathrm{MT}$ \\
\hline NPS & & & & & $1,329.14 \mathrm{MT}$ & 1,238.95 MT & 1,289.3 & 1,285. & 1,258.5 & 321. & 1,344 & 1,40 & & & & 1,06 & 14,946.43 MT \\
\hline NPS & & BF & n & & & & & & & & & & & & & & \\
\hline NPS & & & n & & $217.20 \mathrm{MT}$ & 206.25 MT & & & & & & & & & & 242. & 344 \\
\hline NPSO & & & iselatan & & & & & & & & & & & & & & \\
\hline Pso & & Pso & si Selatan & & ИT & 383.0 & 404. & & 448. & & & & & $517.44 \mathrm{MT}$ & & & $8 \mathrm{MT}$ \\
\hline $\begin{array}{l}\text { PPSO } \\
\text { NPSO }\end{array}$ & $\begin{array}{l}121 \\
50 \\
\end{array}$ & $\mid \begin{array}{l}\text { NNSOO } \\
\text { NPSO }\end{array}$ & $\begin{array}{l}\text { Wesi Selatan } \\
\text { wesi Selatan }\end{array}$ & 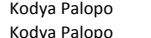 & $\begin{array}{l}173.88 \mathrm{MT} \\
0.50 \mathrm{MT}\end{array}$ & $158.04 \mathrm{MT}$ & $\begin{array}{r}\begin{array}{r}171.00 \mathrm{MT} \\
0.50 \mathrm{MT}\end{array}\end{array}$ & 180.0 & $\begin{array}{r}178.5 \\
0.5\end{array}$ & 184.32 & $1900.4 \mathrm{4}-\mathrm{C}$ & $\begin{array}{l}195.4 \\
0.5\end{array}$ & $\begin{array}{l}150.48 \mathrm{MT} \\
0.50 \mathrm{MT}\end{array}$ & $167.76 \mathrm{MT}$ & & & $\begin{array}{l}2,043.36 \mathrm{MT} \\
\mathbf{3 . 5 0 \mathrm { MT }}\end{array}$ \\
\hline PSO & $3 \mathrm{KG}$ & PSO & Sulawesi Selatan & ya Parepare & $386.40 \mathrm{MT}$ & $342.72 \mathrm{MT}$ & $362.88 \mathrm{MT}$ & $366.24 \mathrm{MT}$ & $389.76 \mathrm{MT}$ & $374.64 \mathrm{MT}$ & 414.96 MT & $384.72 \mathrm{MT}$ & $393.12 \mathrm{MT}$ & $414.96 \mathrm{MT}$ & $347.76 \mathrm{MT}$ & $379.68 \mathrm{MT}$ & \\
\hline & & & west & (a) & (c) & & & & 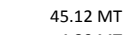 & & & & & & & & $558.36 \mathrm{MT}$ \\
\hline & & & Jlwesi SSlatan & & & & & & & & & & & & & & \\
\hline
\end{tabular}




\section{Lampiran 2}

Energy Balance for Area "Thesis Energy Rishal Asri"

Scenario: Dasar, Year: 2025, Units: Barrel of Oil Equivalent

\begin{tabular}{|c|c|c|c|c|c|c|c|c|c|c|c|c|c|c|c|}
\hline Sektor & Listrik & Gas Bumi & Premium & Avtur & Minyak Tanah & Minyak Solar & Minyak Bakar & LPG & Batubara & Surya & Hidro & LNG & Non BBM & Biodiesel & |Total \\
\hline Production & - & $2,314,802.00$ & - & - & - & - & $\cdot$ & - & - & 0.12 & $1,056,761.71$ & - & - & - & $3,371,563.83$ \\
\hline Imports & - & $3,824,969.41$ & $7,308,187.71$ & $5,205,275,33$ & $361,850.87$ & $6,244,704.96$ & $297,199.23$ & $1,104,328.29$ & $4,591,166.24$ & $4,391.06$ & - & - & 0.07 & $368,327.55$ & $29,310,400,72$ \\
\hline Exports & -0.00 & $-2,199,061.90$ & $\cdot$ & - & - & 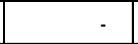 & - & - & - & - & - & -18.85 & - & - & $-2,199,080.75$ \\
\hline Total Primary Supply & -0.00 & $3,940,709.51$ & $7,308,187.71$ & $5,205,275.33$ & $361,850.87$ & $6,244,704.96$ & $297,199.23$ & \begin{tabular}{|l|}
$1,104,328.29$ \\
\end{tabular} & $4,591,166.24$ & $4,391.18$ & $1,056,761.71$ & \begin{tabular}{|l|}
-18.85 \\
\end{tabular} & 0.07 & $368,327.55$ & $30,482,883.81$ \\
\hline Pabrik Biogas & - & - & $\cdot$ & - & - & - & $\cdot$ & - & - & - & - & - & - & - & $\cdot$ \\
\hline Produksi Biomass & . & . & . & . & . & . & . & . & . & . & . & . & . & . & . \\
\hline Tambang Batubara & - & - & - & - & - & - & $\cdot$ & - & - & - & - & $\cdot$ & - & - & $\cdot$ \\
\hline Tambang Gas Bumi & - & $-115,740.10$ & - & - & - & - & - & - & - & - & - & - & - & - & $-115,740.10$ \\
\hline Tambang Minyak Bumi & - & - & - & - & - & - & - & - & - & - & - & - & - & - & - \\
\hline Pencairan Batubara & - & - & - & - & - & - & - & - & - & - & - & - & - & - & 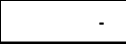 \\
\hline Pabrik Briket & - & - & - & - & - & - & - & - & - & - & - & - & - & - & $\cdot$ \\
\hline Pabrik Bioetanol & - & - & - & - & - & - & - & - & - & - & - & - & - & - & - \\
\hline Pabrik Biodiesel & - & - & - & - & - & - & - & - & - & - & - & - & - & - & $\cdot$ \\
\hline Regasifikasi LNG & - & - & - & - & - & - & - & - & - & - & - & - & - & - & - \\
\hline Kilang LPG & - & - & - & - & - & - & - & - & - & - & - & - & - & - & - \\
\hline Kilang LNG & - & -22.18 & - & - & - & - & - & - & - & - & - & 18.85 & - & - & -3.33 \\
\hline Pembangkit Listrik & $3,859,585.94$ & $-2,127,030.37$ & - & - & - & $-3,063,469.06$ & - & - & $-2,895,285.16$ & $-4,391.18$ & \begin{tabular}{|l|}
$-1,056,761.71$ \\
\end{tabular} & - & - & - & $-5,287,351,54$ \\
\hline Transmisi Distribusi & $-463,150.31$ & - & - & - & - & $\cdot$ & - & - & - & - & - & - & - & - & $-463,150.31$ \\
\hline Total Transformation & $3,396,435.62$ & $-2,242,792.65$ & - & - & - & $-3,063,469.06$ & - & - & $-2,895,285.16$ & $-4,391.18$ & \begin{tabular}{|l|}
$-1,056,761.71$ \\
\end{tabular} & 18.85 & - & - & \begin{tabular}{|l|}
$-5,866,245.28$ \\
\end{tabular} \\
\hline Rumah Tangga & $1,356,915,65$ & $1,689,062.88$ & - & - & $259,526.62$ & - & - & $1,076,327.65$ & - & - & - & - & - & - & $4,381,832,80$ \\
\hline Industri & $901,113.23$ & - & $1,627.35$ & - & 654.84 & $39,763.18$ & $8,178.25$ & - & $1,695,881.08$ & - & - & - & 0.07 & - & $2,647,218.00$ \\
\hline Transportasi & & . & $7,306,560.36$ & \begin{tabular}{|l|}
$5,205,275.33$ \\
\end{tabular} & . & $2,684,204.38$ & $289,020.98$ & 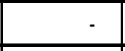 & - & - & - & - & - & $368,327.55$ & \begin{tabular}{|l}
$15,853,388.60$ \\
\end{tabular} \\
\hline Komersial & $1,138,406.75$ & $8,853.98$ & - & - & $101,669.41$ & $122,809.81$ & - & $28,000,64$ & - & - & - & - & - & - & $1,399,740.58$ \\
\hline Khusus & - & - & - & - & - & - & - & - & - & . & - & - & - & - & - \\
\hline Lainnya & - & - & - & - & - & $334,458.55$ & $\cdot$ & - & - & - & - & - & - & - & $334,458.55$ \\
\hline Total Demand & $3,396,435.62$ & $1,697,916.86$ & \begin{tabular}{|l|}
$7,308,187.71$ \\
\end{tabular} & $5,205,275.33$ & $361,850.87$ & $3,181,235.91$ & $297,199.23$ & $1,104,328.29$ & $1,695,881.08$ & & 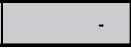 & - & 0.07 & $368,327.55$ & $24,616,638.53$ \\
\hline
\end{tabular}




\section{Lampiran 3}

Energy Balance for Area "Thesis Energy Rishal Asri"

Scenario: Dasar, Year: 2050, Units: Barrel of Oil Equivalent

\begin{tabular}{|c|c|c|c|c|c|c|c|c|c|c|c|c|c|c|c|}
\hline Sektor & Listrik & Gas Bumi & Premium & Avtur & Minyak Tanah & Minyak Solar & Minyak Bakar & LPG & Batubara & Surya & Hidro & LNG & Non BBM & Biodiesel & Total \\
\hline Production & . & $1,864,000.00$ &. & . &. & - & - & . &. & 0.12 & $8,122,785.18$ & - &. & - & $9,986,785.31$ \\
\hline Imports & - & $4,343,636.18$ & $10,687,634.40$ & $44,459,942.01$ & $1,192,963.60$ & $23,425,947.84$ & $2,538,474.83$ & $1,562,055.62$ & $26,335,514.27$ & $3,594.51$ & $7,955,552.35$ & - & 0.62 & $1,061,410.58$ & $123,566,726.82$ \\
\hline Exports & -0.00 & $-2,199,061.90$ & - & - & - & - & - & - & - & - & - & -18.85 & - & - & $-2,199,080.75$ \\
\hline Total Primary Supply & -0.00 & $4,008,574.28$ & $10,687,634.40$ & \begin{tabular}{|l|}
$44,459,942.01$ \\
\end{tabular} & $1,192,963.60$ & \begin{tabular}{|l|}
$23,425,947.84$ \\
\end{tabular} & \begin{tabular}{|l|}
$2,538,474.83$ \\
\end{tabular} & \begin{tabular}{|l|}
$1,562,055.62$ \\
\end{tabular} & $26,335,514.27$ & $3,594.63$ & $16,078,337.53$ & -18.85 & 0.62 & $1,061,410.58$ & \begin{tabular}{|l|}
$131,354,431.37$ \\
\end{tabular} \\
\hline Pabrik Biogas & - & - & - & - & - & - & - & - & - & - & - & - & - & - & - \\
\hline Produksi Biomass & - & - & - & - & - & - & - & - & - & - & - & - & - & - & $\cdot$ \\
\hline Tambang Batubara & - & - & - & - & - & - & - & - & - & - & - & - & - & - & - \\
\hline Tambang Gas Bumi & - & $-115,740,10$ & - & - & - & - & - & - & - & - & - & - & - & - & $-115,740,10$ \\
\hline Tambang Minyak Bumi & - & - & - & - & - & - & - & - & - & - & - & - & 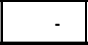 & - & 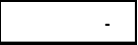 \\
\hline Pencairan Batubara & - & - & - & - & - & - & - & - & - & - & - & - & - & - & - \\
\hline Pabrik Briket & - & . & - & . & - & - & . & - & . & . & - & - & . & . & . \\
\hline Pabrik Bioetanol & - & - & - & - & - & - & - & - & - & - & - & - & - & - & - \\
\hline Pabrik Biodiesel & . & . & - & . & - & . & . & - & . & . & - & - & . & . & - \\
\hline Regasifikasi LNG & - & - & - & - & - & - & - & - & - & - & - & - & - & - & - \\
\hline Kilang LPG & . & - & - & - & - & - & - & - & - & - & - & - & - & - & - \\
\hline Kilang LNG & . & -22.18 & - & - & - & - & - & - & . & - & - & 18.85 & - & - & -3.33 \\
\hline Pembangkit Listrik & $21,690,862.27$ & $-1,741,193.33$ & - & - & - & $-2,507,764.80$ & - & - & $-11,850,444.85$ & $-3,594.63$ & $-16,078,337.53$ & - & - & - & $-10,490,472.89$ \\
\hline Transmisi Distribusi & $-2,602,903.47$ & - & - & - & - & - & - & - & - & - & - & - & - & - & $-2,602,903.47$ \\
\hline Total Transformation & $19,087,958.80$ & $-1,856,955,61$ & - & - & - & \begin{tabular}{|l|}
$-2,507,764.80$ \\
\end{tabular} & - & - & $-11,850,444,85$ & $-3,594.63$ & \begin{tabular}{|l|}
$-16,078,337.53$ \\
\end{tabular} & 18.85 & - & - & $-13,209,119.78$ \\
\hline Rumah Tangga & $1,667,758.30$ & 2,075,993.93 & - & - & $318,979.05$ & - & - & $1,322,893.13$ & - & - & - & - & - & - & $5,385,624,42$ \\
\hline Industri & $7,696,699.86$ & $\cdot$ & 13,899.72 & - & $5,593.19$ & $339,630.15$ & $69,853.06$ & - & $14,485,069.42$ & 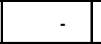 & - & - & 0.62 & - & $22,610,746.02$ \\
\hline Transportasi & & - & $10,673,734,68$ & \begin{tabular}{|l|}
$44,459,942.01$ \\
\end{tabular} & $\cdot$ & \begin{tabular}{|l|}
$16,672,875.82$ \\
\end{tabular} & \begin{tabular}{|l|}
$2,468,621.77$ \\
\end{tabular} & - & - & - & - & 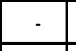 & - & $1,061,410.58$ & $75,336,584.86$ \\
\hline Komersial & $9,723,500.64$ & $75,624.73$ & - & - & $868,391.36$ & $1,048,958.31$ & - & $239,162.49$ & - & - & - & - & - & - & $11,955,637.53$ \\
\hline Khusus & - & - & - & - & - & - & - & - & - & - & - & - & - & - & - \\
\hline Lainnya & - & - & - & - & - & $2,856,718.76$ & - & - & - & - & - & - & - & - & $2,856,718.76$ \\
\hline Total Demand & $19,087,958.80$ & 2,151,618.66 & $10,687,634.40$ & 44,459,942.01 & $1,192,963.60$ & 20,918,183.04 & $2,538,474.83$ & $1,562,055.62$ & $14,485,069.42$ & - & - & - & 0.62 & $1,061,410.58$ & $118,145,311.59$ \\
\hline
\end{tabular}




\section{Lampiran 4}

hergy Balance for Area "Thesis Energy Rishal Assi"

Scenario: RE, Year: 2025, Units: Barrel of OOil Equivalent

\begin{tabular}{|c|c|c|c|c|c|c|c|c|c|c|c|c|c|c|c|c|c|c|c|c|}
\hline Sektor & Listrik & Gas Bumi & Premium & Avtur & Minyak Tanah & Minyaksolar N & Minyak Bakar & PPG & Batubara & Biogas & Bioethanol & Angin & Surva & Hidro & Panasbumi & Biomass & LNG & Non BBM & Biodiesel & Total \\
\hline Production & . & $2,314,802,00$ &. & $\cdot$ & . &. & $\cdot$ & $\cdot$ & 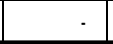 & . & $\cdot$ & $\cdot$ & 0.12 & $1,364,388.41$ & 77,896.59 & $\cdot$ & $\cdot$ & $\cdot$ & $\cdot$ & $3,757,087,13$ \\
\hline Imports & $\cdot$ & $3,973,662,36$ & $5,589,322.37$ & $5,205,275.33$ & $361,850.87$ & $4,163,493.90$ & $297,199.23$ & $1,104,328.29$ & 4,194,641.94 & $343,654,76$ & $1,718,845.85$ & $14,942.40$ & $39,623.00$ & $\cdot$ & $\cdot$ & $66,229.01$ & $\cdot$ & 0.07 & $433,551,72$ & $27,507,021.09$ \\
\hline Exports & -0.00 & $-2,199,061.90$ & & $\cdot$ & $\cdot$ &. & & & & 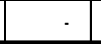 & & $\cdot$ & $\cdot$ & & $\cdot$ & & -32.24 & $\cdot$ & & $-2,199,094,14$ \\
\hline Total Primary Supply & -0.00 & \begin{tabular}{|l|}
$4,089,402,46$ \\
\end{tabular} & 5,589,322.37 & $5,205,275.33$ & $361,850.87$ & $4,163,493.90$ & $297,199.23$ & $1,104,328.29$ & 4,194,641.94 & $343,654,76$ & $1,718,845.85$ & $14,942,40$ & 39,623.12 & $1,364,388.41$ & 77,896.59 & 66,229.01 & -32.24 & 0.07 & $433,551,72$ & $29,065,014.08$ \\
\hline Pabrik Biogas & $\cdot$ & $\cdot$ & . & $\cdot$ & . & . & $\cdot$ & . & r & . & & $\cdot$ & . & . & . & . & . & $\cdot$ & ${ }^{\circ}$ & . \\
\hline Produksi Biomass & . & . & . & . & . & . & $\cdot$ & $\cdot$ & . & . & . & . & $\cdot$ & . & . & $\cdot$ & . & $\cdot$ & . & . \\
\hline Tambang Batubara & . & . & . & . & . & . & $\cdot$ & $\cdot$ & . & . & . & . & $\cdot$ & . & . & $\cdot$ & . & $\cdot$ & $\cdot$ & . \\
\hline Tambang Gas Bumi & - & $-115,740,10$ & - & . & . & . & $\cdot$ & $\cdot$ & - & . & - & . & $\cdot$ & . & - & $\cdot$ & . & $\cdot$ & . & - $115,740.10$ \\
\hline Tambang Minyak Bumi & & $\cdot$ & - & . & . & . & & $\cdot$ & r & . & & . & $\cdot$ & . & - & . & . & $\cdot$ & . & . \\
\hline Pencairan Batubara & . & . & $\cdot$ & . & . & $\cdot$ & . & $\cdot$ & . & $\cdot$ & - & $\cdot$ & $\cdot$ & . & $\cdot$ & . & . & $\cdot$ & . & . \\
\hline Pabrik Briket & - & . & $\cdot$ & . & . & . &. & $\cdot$ & . & . & $\cdot$ & . & $\cdot$ & . & $\cdot$ &. & . &. & . &. \\
\hline Pabrik Bioetanol & - &. & $\cdot$ & $\cdot$ & . & $\cdot$ & $\cdot$ & $\cdot$ & $\cdot$ & $\cdot$ & 19.49 & $\cdot$ & $\cdot$ & $\cdot$ & $\cdot$ & -19.89 & . & $\cdot$ & $\cdot$ & -0.40 \\
\hline Pabrik Biodiesel & . & . & $\cdot$ & . & . & . & $\cdot$ & $\cdot$ & . & . & $\cdot$ & . & $\cdot$ & . & $\cdot$ & -22.47 & . & $\cdot$ & 22.02 & -0.45 \\
\hline Regasifikasi LNG & - & . & $\cdot$ & $\cdot$ & . & . & $\cdot$ & $\cdot$ & . & . & $\cdot$ & - & $\cdot$ & . & $\cdot$ & $\cdot$ & . & $\cdot$ & . & . \\
\hline Kilang $L P G$ & & . & $\cdot$ & . & . & . & . & . & . & . & . & . & $\cdot$ & . & . & . & . & $\cdot$ & . & . \\
\hline Kilang LNG & & -37.93 & $\cdot$ & $\cdot$ & $\cdot$ & $\cdot$ & $\cdot$ & $\cdot$ & . & $\cdot$ & $\cdot$ & $\cdot$ & $\cdot$ & . & $\cdot$ & . & 32.24 & $\cdot$ & . & -5.69 \\
\hline Pembangkit Listrik & 3,859,585.94 & $-2,622,596,45$ & $\cdot$ & . & . & $-982,257,99$ & $\cdot$ & $\cdot$ & $-2,498,760.86$ & $\cdot$ & . & $-14,942,40$ & \begin{tabular}{|l|}
$-39,623.12$ \\
\end{tabular} & $-1,364,388.41$ & $-77,896,59$ & $-66,186,65$ & $\cdot$ & $\cdot$ & - & $-3,808,066.54$ \\
\hline Trannmisi Distribusi & $-463,150,31$ & . & . & . & . & . & $\cdot$ & . & . & . & . & . & . & . & . & $\cdot$ & . & $\cdot$ & $\cdot$ & $-463,150,31$ \\
\hline Total Transformation & $3,396,435.62$ & $-2,739,374,48$ & . & . & . & $-982,257.99$ & 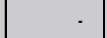 & $\cdot$ & $-2,498,760.86$ & . & 19.49 & $-14,942.40$ & $-39,623.12$ & $-1,364,388.41$ & $-77,896.59$ & $\mid-66,229.01$ & 32.24 & - & 22.02 & $-4,386,963.49$ \\
\hline Rumah Tangga & $1,356,915.65$ & 1,341,173.99 & & . & $259,526.62$ & . & & $\mid 1,076,327,65$ & & $343,654,76$ & & . & $\cdot$ & . & . & . & . & $\cdot$ & . & $4,377,598.67$ \\
\hline Industri & $901,113,23$ & & $1,627,35$ & . & 654.84 & $39,763.18$ & $8,178.25$ & . & 1,695,881.08 & . & & . & $\cdot$ & . & $\cdot$ & . & . & 0.07 & - & $2,647,218.00$ \\
\hline Transportasi & & . & $5,587,695.02$ & $5,205,275.33$ & . & $2,684,204,38$ & $289,020.98$ & $\cdot$ & . & $\cdot$ & $1,718,865.34$ & . & $\cdot$ & . & $\cdot$ & . & . & $\cdot$ & $433,973,74$ & $15,919,034,79$ \\
\hline Komersial & $1,138,406.75$ & $8,853.98$ & $\cdot$ & $\cdot$ & 101, 669.41 & $122,809.81$ & $\cdot$ & $28,000.64$ & . & $\cdot$ & $\cdot$ & $\cdot$ & $\cdot$ & . & $\cdot$ & $\cdot$ & . & $\cdot$ & $\cdot$ & $1,399,740,58$ \\
\hline Khusus & - & $\cdot$ & $\cdot$ & $\cdot$ & $\cdot$ & $\cdot$ & $\cdot$ & $\cdot$ & $\cdot$ & $\cdot$ & $\cdot$ & $\cdot$ & $\cdot$ & . & $\cdot$ &. &. & $\cdot$ & $\cdot$ & $\cdot$ \\
\hline Lànnya & . & . & . & $\cdot$ & . & $334,458.55$ &. & $\cdot$ & . &. & . &. &. &. & $\cdot$ & $\cdot$ & . &. & . & $334,458.55$ \\
\hline Total Demand & 3,396,435.62 & \begin{tabular}{|l|}
$1,350,027.97$ \\
\end{tabular} & 5,589,322.37 & $5,205,275.33$ & 361,850.87 & 3,181,235.91 & $297,199.23$ & $1,104,328.29$ & 1,695,881.08 & $343,654,76$ & 1,718,865.34 & & & & & & - & 0.07 & $433,973,74$ & $24,678,050,58$ \\
\hline
\end{tabular}




\section{Lampiran 5}

eergy Balance for Area "Thesis Energy Rishal Ass"

Scenario: RES, Year: 2050, Units: Barrel of Oil Equivalent

\begin{tabular}{|c|c|c|c|c|c|c|c|c|c|c|c|c|c|c|c|c|c|c|c|c|}
\hline Seltor & Listrik & Gas Bumi & Premium & Avtur & \begin{tabular}{|l|} 
Minyak Tanah \\
\end{tabular} & \begin{tabular}{|l|} 
Minyak Solar \\
\end{tabular} & Minyak Bakar & $P P G$ & Batubara & Biogas & Bioethanol A & Angin & Surpa & Hidro & Panassumi & Biomass & \begin{tabular}{|l|l|} 
LNG & $N$ \\
\end{tabular} & Non BBM & Biodiesel & Total \\
\hline Production & $\cdot$ & $1,864,000,00$ & $\cdot$ & $\cdot$ & $\cdot$ & $\cdot$ & $\cdot$ & . & $\cdot$ & $\cdot$ & . & $\cdot$ & 0.12 & $8,122,785.18$ & $606,558.55$ & $\cdot$ & $\cdot$ & $\cdot$ & $\cdot$ & $10,593,343,86$ \\
\hline Imports & . & $8,409,074,66$ & \begin{tabular}{|l|l|}
6 & $3,005,354.61$ \\
\end{tabular} & $44,459,442.01$ & $1,192,963.60$ & 23,801,678.64 & 2,538,474.83 & 1,562,055.62 & 23,515,358.56 & $1,382,332,25$ & $7,682,216,00$ & 450,019.27 & $251,955.57$ & $4,335,724.68$ & $942,218,32$ & $595,075.32$ & & 0.62 & $3,3110,199.82$ & $127,834,644,39$ \\
\hline Exports & -0.00 & $-2,199,061.90$ & $\cdot$ & $\cdot$ & $\cdot$ & $\cdot$ & $\cdot$ & & $\cdot$ & $\cdot$ &. & $\cdot$ & $\cdot$ & $\cdot$ & $\cdot$ & $\cdot$ & -109.19 & $\cdot$ & $\cdot$ & $-2,199,171.09$ \\
\hline Total Primary Supply & -0.00 & $8,074,0127.76$ & \begin{tabular}{|l|l|}
$6,305,354,61$ \\
\end{tabular} & $44,459,942.01$ & $1,192,963.60$ & $23,801,678.64$ & $2,538,474.83$ & 1,562,055.62 & $23,515,358.56$ & $1,382,332,25$ & $7,682,216.00$ & 450,019.27 & $251,955.69$ & $12,458,509.86$ & $1,548,776.87$ & $595,075.32$ & -109.19 & 0.62 & $3,110,199.82$ & $136,228,817,16$ \\
\hline Pabrik Biogas & $\cdot$ & 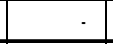 & $\cdot$ & $\cdot$ & $\cdot$ & $\cdot$ & $\cdot$ & 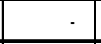 & $\cdot$ & $\cdot$ & $\cdot$ & $\cdot$ & $\cdot$ & $\cdot$ & $\cdot$ & $\cdot$ & $\cdot$ & $\cdot$ &. & $\cdot$ \\
\hline Produksi Biomass &. &. & $\cdot$ & $\cdot$ & $\cdot$ & $\cdot$ & $\cdot$ & 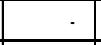 & $\cdot$ & $\cdot$ & $\cdot$ & $\cdot$ & . & $\cdot$ & - &. & - & $\cdot$ &. & 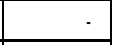 \\
\hline Tambang Batubara & $\cdot$ & $\cdot$ & $\cdot$ & $\cdot$ & $\cdot$ & $\cdot$ & $\cdot$ & $\cdot$ & $\cdot$ & $\cdot$ & $\cdot$ & $\cdot$ & . & $\cdot$ & $\cdot$ & $\cdot$ & $\cdot$ & $\cdot$ & $\cdot$ & $\cdot$ \\
\hline Tambann Gas Bumi & . & $-115,740,10$ & $\cdot$ & $\cdot$ & $\cdot$ & $\cdot$ & . & . & $\cdot$ & $\cdot$ & . & $\cdot$ & . & $\cdot$ & $\cdot$ & . & . & $\cdot$ & . & . $.115,740.10$ \\
\hline Tambang Minyak Bumi & $\cdot$ & . & $\cdot$ & $\cdot$ & . & $\cdot$ & $\cdot$ & $\cdot$ & $\cdot$ & $\cdot$ & $\cdot$ & $\cdot$ & $\cdot$ & $\cdot$ & - & $\cdot$ & & $\cdot$ & $\cdot$ & . \\
\hline Pencairan Batubara & $\cdot$ &. & $\cdot$ & $\cdot$ &. & $\cdot$ &. & $\cdot$ & $\cdot$ & $\cdot$ & $\cdot$ &. & . &. & 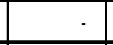 &. &. &. &. & $\cdot$ \\
\hline Pabrik Briket & . & & & . & . & $\cdot$ & . & & . &. & . & . & ${ }^{\circ}$ & $\cdot$ & & $\cdot$ & &. & . & . \\
\hline Pabrik Bioetanol & . & . & $\cdot$ & $\cdot$ & 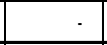 & $\cdot$ & $\cdot$ & . & $\cdot$ & $\cdot$ & 63.78 & $\cdot$ & $\cdot$ & $\cdot$ & & 65.09 & 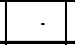 & $\dot{ }$ & $\cdot$ & $-1,30$ \\
\hline Pabrik Biodiesel & $\cdot$ & $\cdot$ & . & $\dot{-}$ & $\dot{-}$ & $\cdot$ & $\cdot$ & $\cdot$ & $\cdot$ & $\cdot$ & $\cdot$ & $\cdot$ & . & $\cdot$ & - & .73 .54 & & $\cdot$ & 72.07 & -1.47 \\
\hline Regasifikasi LNG & $\cdot$ & $\cdot$ & . & $\cdot$ & $\cdot$ & $\cdot$ & $\cdot$ & $\cdot$ & $\cdot$ & $\cdot$ & $\cdot$ & $\cdot$ & $\cdot$ & $\cdot$ & $\cdot$ & $\cdot$ & $\cdot$ & $\cdot$ & $\cdot$ & $\cdot$ \\
\hline Kilang LPG & $\dot{-}$ & $\cdot$ & . & . & $\cdot$ & $\cdot$ & . & . & $\cdot$ & $\cdot$ & . & . & . & $\cdot$ & & . & 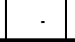 & . & . & . \\
\hline Kiang LNG & $\cdot$ & .128 .46 & . & - & $\dot{5}$ & $\cdot$ & $\cdot$ & $\cdot$ & $\cdot$ & $\cdot$ & $\cdot$ & 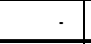 & $\cdot$ & $\cdot$ & $\cdot$ & $\cdot$ & 109.19 & $\cdot$ & $\cdot$ & .19 .27 \\
\hline Pembanghit listrik & $21,960,3220,40$ & $-7,205,889,34$ & $\cdot$ & $\cdot$ & $\cdot$ & $-2,697,839.60$ & $\cdot$ & $\cdot$ & $-9,030,289.14$ & $\cdot$ & $\cdot$ & $-450,019.27$ & $-251,955.69$ & $-12,458,509.86$ & $-1,548,776.87$ & $-594,396,70$ & . & $\cdot$ & . & $-12,277,896.07$ \\
\hline Transmisi Distribusi & $-2,635,238,45$ & & & . & $\cdot$ & & $\cdot$ & & & $\cdot$ & $\cdot$ & & &. & & $\cdot$ & & $\cdot$ & $\cdot$ & $-2,635,238.45$ \\
\hline Total Transformation & $19,325,081.95$ & $-7,321,757,90$ & . & . & . & $-2,697,839.60$ & 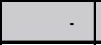 & & $-9,030,289.14$ & $\cdot$ & 63.78 & $-450,019.27$ & $-251,955.69$ & $-12,458,509.86$ & $-1,548,776,87$ & $-595,075.32$ & 109.19 &. & 72.07 & $-15,028,896,66$ \\
\hline Rumah Tangga & $1,667,758,30$ & $676,630,13$ & & $\dot{5}$ & $318,779.05$ & $\cdot$ & $\cdot$ & $1,322,893,13$ & & $1,382,332,25$ & 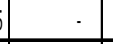 & . & . & $\cdot$ & & $\cdot$ & &. & 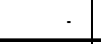 & $5,368,592,86$ \\
\hline Industri & $7,696,699.86$ & $\cdot$ & $13,899.72$ & . & $5,593.19$ & $339,630,15$ & $69,853.06$ & . & 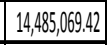 & $\cdot$ & . & $\cdot$ & . & $\cdot$ &. &. &. & 0.62 & $\cdot$ & $22,610,746.02$ \\
\hline Transportasi & $237,123,15$ & $\cdot$ & 2,991,454.89 & $44,459,942.01$ & $\cdot$ & 16,858,531.82 & 2,468,621.77 & . & $\cdot$ & $\cdot$ & $7,682,279,79$ & $\cdot$ & 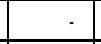 & $\cdot$ & 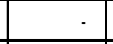 &. & . &. & $3,310,271.89$ & $78,408,225,33$ \\
\hline Komersial & $9,723,500,64$ & $75,624,73$ & . & . & $868,391.36$ & $1,048,958.31$ & . & $239,162,49$ & $\cdot$ & $\cdot$ & $\cdot$ & . &. & $\cdot$ & & $\cdot$ & 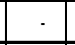 &. & $\cdot$ & $11,955,677.53$ \\
\hline Khusus & $\cdot$ & $\cdot$ &. & . & $\cdot$ & $\cdot$ & $\cdot$ &. & $\cdot$ & $\cdot$ &. & . & . & $\cdot$ &. &. &. & $\cdot$ & . & $\cdot$ \\
\hline Lainnya & $\cdot$ & $\cdot$ & $\dot{.}$ & 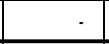 & 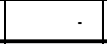 & $2,856,718.76$ & $\cdot$ & . & $\cdot$ & $\cdot$ & $\cdot$ & 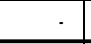 & 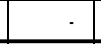 & $\cdot$ & $x$ & $\cdot$ & $\dot{.}$ & $\cdot$ & $\cdot$ & $2,856,718.76$ \\
\hline Total Demand & $19,325,081.95$ & $752,254.86$ & $3,005,354,61$ & 44,459,942.01 & 1,192,963.60 & 21,103,839.04 & 2,538,477.83 & 1,562, 055.62 & $14,485,069.42$ & $1,382,332.25$ & $7,682,279.79$ & & & & & . & & 0.62 & $3,710,271.89$ & $121,199,920.49$ \\
\hline
\end{tabular}




\section{Lampiran 6}

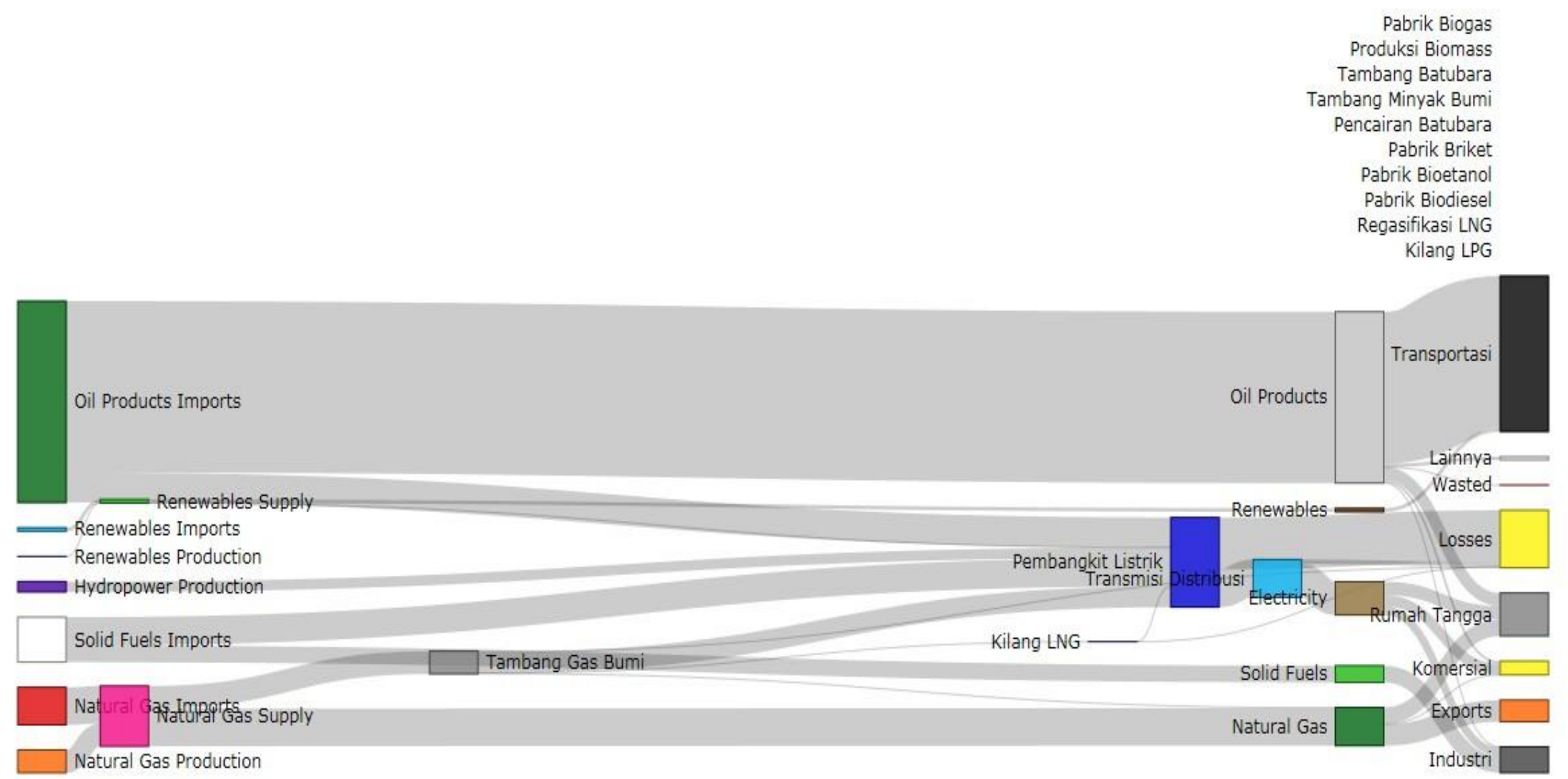

Gambar 6.1 Aliran Energi Skenario BaU tahun 2025 Sulawesi Selatan 


\section{Lampiran 7}

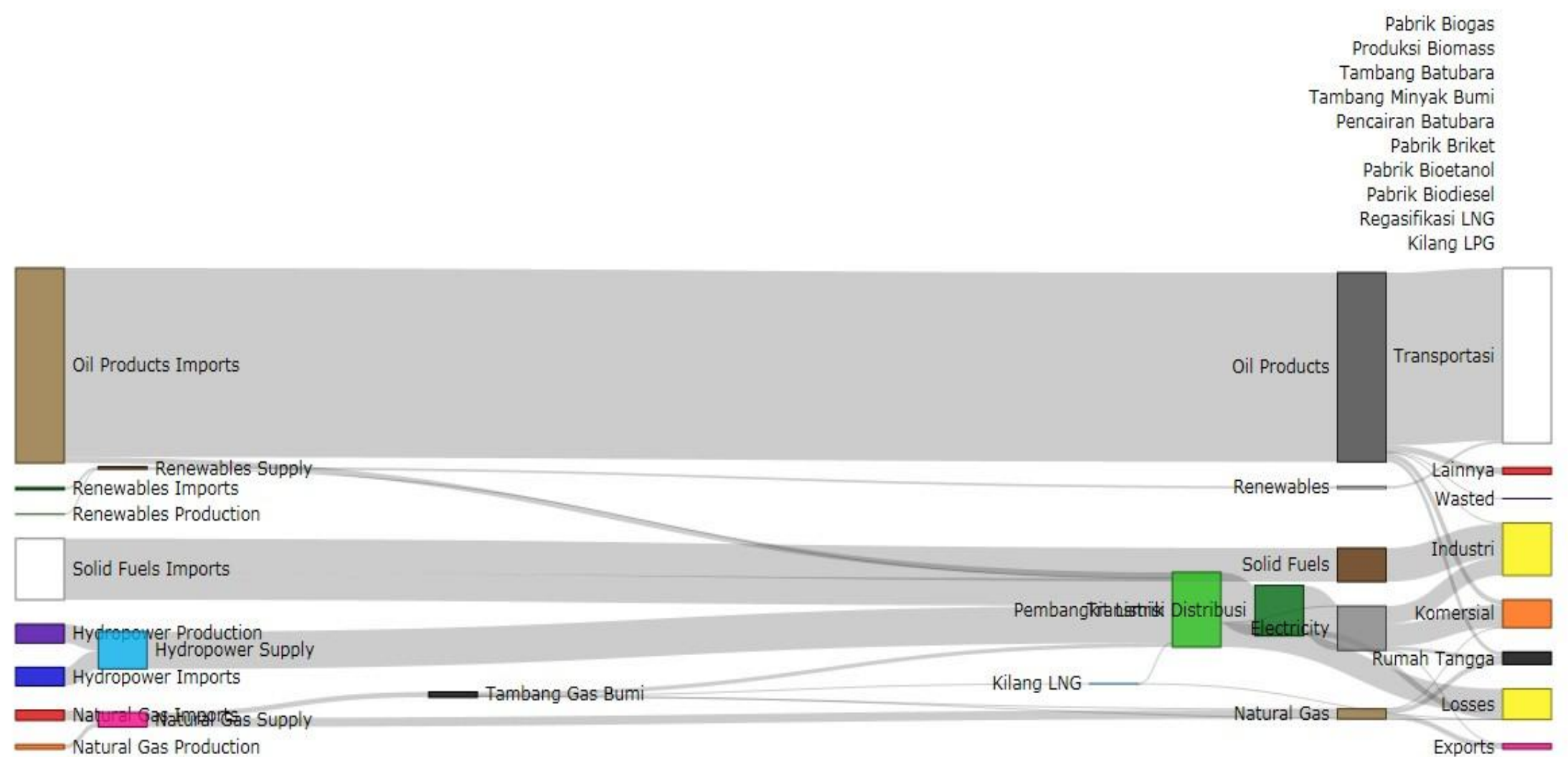

Gambar 6.2 Aliran Energi Skenario CE tahun 2050 Sulawesi Selatan 


\section{Lampiran 8}

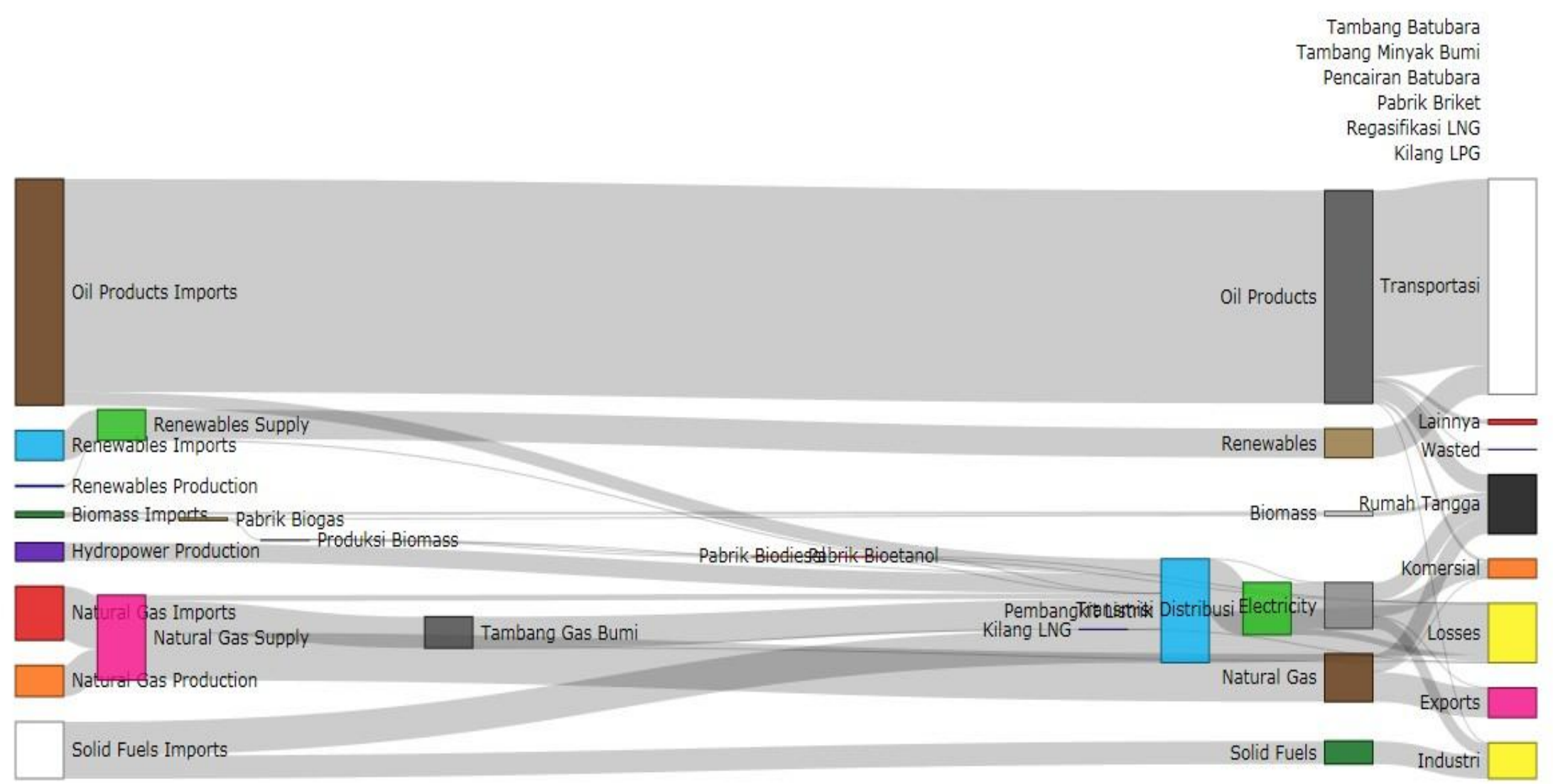

Gambar 6.3 Aliran Energi Skenario CE tahun 2025 Sulawesi Selatan 
Lampiran 9

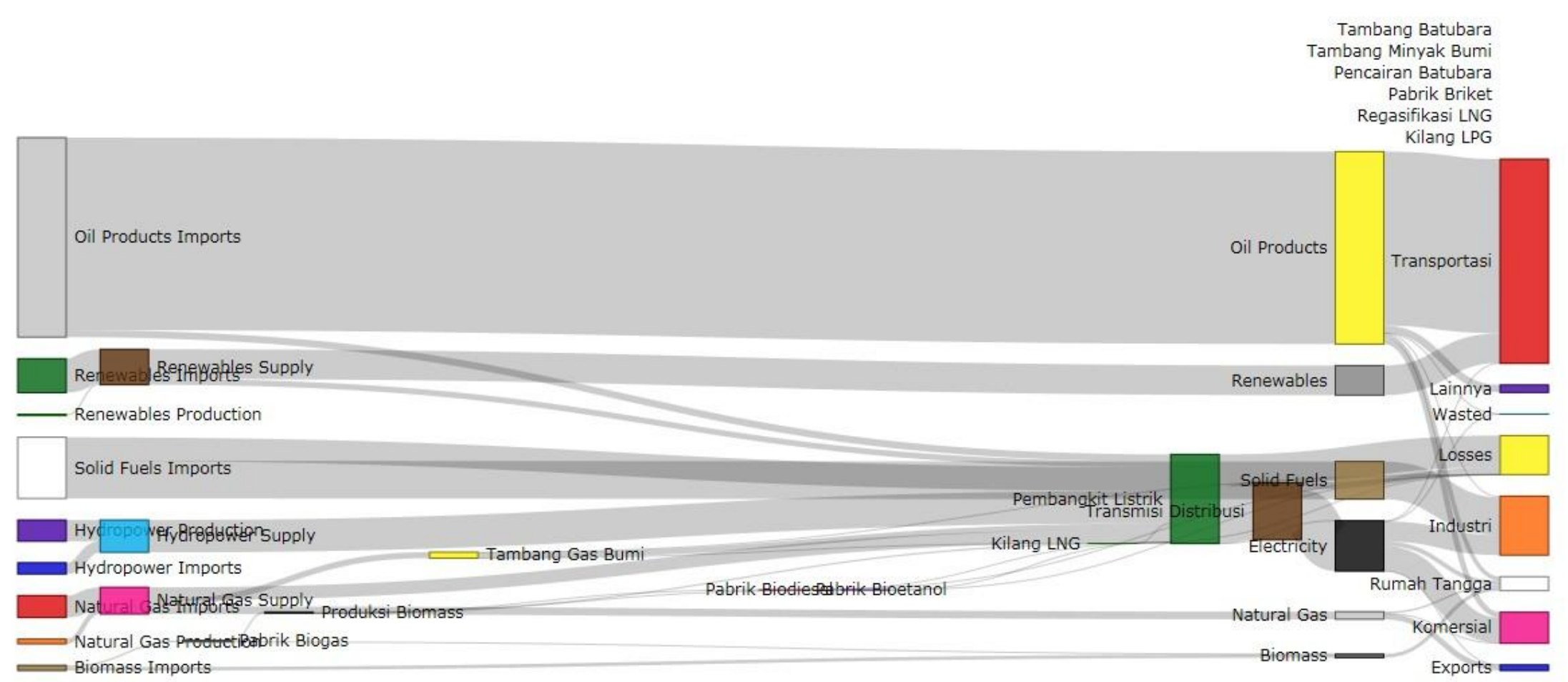

Gambar 6.4 Aliran Energi Skenario CE tahun 2050 Sulawesi Selatan 
Lampiran 10 Harga minyak 2014

MONTHLY REPORT
INDONESAA CRUDE PRICE (ICP)

\begin{tabular}{|c|c|c|c|c|c|c|c|c|c|c|c|c|c|c|c|}
\hline \multirow{2}{*}{ No } & \multirow[t]{2}{*}{ Jenis Minyak Mentah Indonesia } & \multirow{2}{*}{ Formula } & \multicolumn{12}{|c|}{$\begin{array}{l}2.0014 \\
\text { HARGA USSIBBL }\end{array}$} & \multirow{2}{*}{ Average } \\
\hline & & & Jan. & Feb. & Mar. & Apr. & Mei. & Juni & Juli & Aug. & Sep. & Oct. & Nov. & Dec. & \\
\hline & \begin{tabular}{|l} 
A Harg \\
Sic
\end{tabular} & & 110.03 & 108 & 112 & & & & 105,06 & 100,00 & 95,66 & 84,46 & & & \\
\hline 2 & Apjuna & 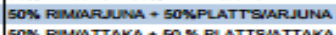 & 102,77 & 104.13 & 102,85 & 108,08 & 104.23 & 107.25 & 103,75 & 98,74 & 94,12 & 83,11 & 74,63 & 59,14 & 94,82 \\
\hline 3 & $\begin{array}{l}\text { Attaka } \\
\text { Cinta }\end{array}$ & & $\begin{array}{l}105,89 \\
10967\end{array}$ & $\begin{array}{l}107.30 \\
10565\end{array}$ & $\begin{array}{l}106,20 \\
107.92\end{array}$ & $\begin{array}{l}106,44 \\
10569\end{array}$ & $\begin{array}{l}107.77 \\
108.62\end{array}$ & $\begin{array}{l}110,36 \\
108,72\end{array}$ & $\begin{array}{l}106,92 \\
104,79\end{array}$ & $\begin{array}{l}101,81 \\
100,35\end{array}$ & $\begin{array}{c}97.09 \\
95.80\end{array}$ & $\begin{array}{l}86,06 \\
84,09\end{array}$ & 77,59 & $\begin{array}{r}62,13 \\
60.45\end{array}$ & 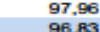 \\
\hline 5 & \begin{tabular}{|lllll} 
Canta \\
Duri
\end{tabular} & 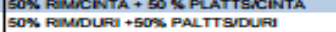 & $\begin{array}{l}100,67 \\
102,80\end{array}$ & $\begin{array}{l}105.65 \\
104,02\end{array}$ & $\begin{array}{l}107.92 \\
104,76 \\
-150\end{array}$ & 100,44 & 104.46 & $\begin{array}{l}108,72 \\
106,86\end{array}$ & $\begin{array}{l}103,47 \\
103,49\end{array}$ & $\begin{array}{r}100.35 \\
98,65\end{array}$ & 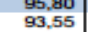 & $\begin{array}{l}84.450 \\
82,40\end{array}$ & $\begin{array}{l}76,37 \\
73,54\end{array}$ & $\mid \begin{array}{lll}58.04 \\
58.04\end{array}$ & $\begin{array}{l}96,83 \\
94,67\end{array}$ \\
\hline 6 & $\begin{array}{l}\text { Widuri } \\
\text { Befliga }\end{array}$ & SON FEMMMDURI + 50 \& PLATTSY WIDUFA & 104,75 & 105.84 & 108,03 & 105,91 & 106,66 & 109.27 & 105,88 & 100,45 & $\begin{array}{l}95,79 \\
99.70\end{array}$ & 85,05 & 76,50 & 60.21 & 97,08 \\
\hline 8 & Senipah Condensale & 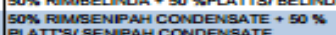 & $\begin{array}{r}108,60 \\
106,43\end{array}$ & 107.62 & 106,41 & 106,89 & 108.29 & 110,40 & $\begin{array}{l}106,89 \\
107,46\end{array}$ & 101,88 & 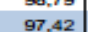 & $\begin{array}{l}87,711 \\
86,11\end{array}$ & 79,68 & 63.86 & 99,63 \\
\hline & B. Harga Minyak Mentah Lainya & & & & & & & & & & & & & & \\
\hline$\frac{9}{10}$ & $\begin{array}{l}\text { Aaroa } \\
\text { Arun Condensate }\end{array}$ & 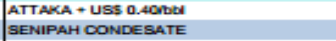 & $\begin{array}{l}10.29 \\
108,43\end{array}$ & $\begin{array}{l}1077.70 \\
107,62\end{array}$ & $\begin{array}{l}106,60 \\
106,41\end{array}$ & $\begin{array}{l}106,84 \\
108,89\end{array}$ & $\begin{array}{l}108.17 \\
108.29\end{array}$ & $\begin{array}{l}110,76 \\
110.40\end{array}$ & $\begin{array}{l}107,32 \\
107.46\end{array}$ & $\begin{array}{l}102,21 \\
101,88\end{array}$ & $\begin{array}{l}97,49 \\
97,42\end{array}$ & $\begin{array}{l}86,46 \\
86,14\end{array}$ & $\begin{array}{ll}77,99 \\
77,93\end{array}$ & $\begin{array}{r}62,53 \\
62,17\end{array}$ & $\begin{array}{l}98,36 \\
98,25\end{array}$ \\
\hline 11 & Badak & ATTAKA & $\begin{array}{l}105,89 \\
105,89\end{array}$ & $\begin{array}{l}107.30 \\
10730\end{array}$ & $\begin{array}{l}106,20 \\
10620\end{array}$ & $\begin{array}{l}106,44 \\
106844\end{array}$ & $\begin{array}{l}107,77 \\
107.77\end{array}$ & $\begin{array}{r}110,36 \\
110.36\end{array}$ & $\begin{array}{l}106,92 \\
106,92\end{array}$ & $\begin{array}{l}101,81 \\
101,81\end{array}$ & $\begin{array}{c}97.09 \\
97.09\end{array}$ & $\begin{array}{l}86,06 \\
88,06\end{array}$ & 77,59 & 62,13 & 97,96 \\
\hline & $\begin{array}{l}\text { Beckapai } \\
\text { Betapak }\end{array}$ & 㝐TINA & $\begin{array}{r}105.89 \\
9781\end{array}$ & $\begin{array}{l}107.30 \\
90917\end{array}$ & $\begin{array}{l}106.20 \\
97.89\end{array}$ & & 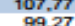 & $\begin{array}{l}110.36 \\
1020\end{array}$ & 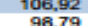 & & & $\begin{array}{l}86.06 \\
78.15\end{array}$ & $\begin{array}{l}77.59 \\
69.67\end{array}$ & 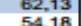 & $\begin{array}{l}97.96 \\
89.86\end{array}$ \\
\hline 14 & Bentayan & SLC- USS 1.9650 A & 108.07 & 106.75 & 110,50 & $\begin{array}{r}\$ 69,12 \\
109,09\end{array}$ & 106.21 & 109.65 & $\begin{array}{r}98,19 \\
103,10\end{array}$ & 98,04 & $\begin{array}{l}89.18 \\
93.70\end{array}$ & 82,50 & 74.37 & 58,04 & $\begin{array}{l}96,67 \\
96,67\end{array}$ \\
\hline 15 & Bontang Return Cond, (BRC) & MOPS NAPHTHA - USS 2.007DA & 102,47 & 100.37 & 100,08 & 101,99 & 103.31 & 104,17 & 104,34 & 96,87 & 92,45 & 77,79 & 69.86 & 54,33 & 92,34 \\
\hline $\begin{array}{l}16 \\
17\end{array}$ & $\begin{array}{l}\text { Buta } \\
\text { Bungu }\end{array}$ & $\begin{array}{l}\text { Durt-us } \\
\text { sLC }\end{array}$ & $\begin{array}{l}102,30 \\
11003\end{array}$ & $\begin{array}{l}103.52 \\
10871\end{array}$ & $\begin{array}{l}104,26 \\
112,46\end{array}$ & $\begin{array}{l}102,94 \\
11105\end{array}$ & $\begin{array}{l}103,96 \\
108.17\end{array}$ & $\begin{array}{l}106,36 \\
111,61\end{array}$ & $\begin{array}{l}102,97 \\
105,06\end{array}$ & 98,15 & $\begin{array}{c}93.05 \\
99.66\end{array}$ & 81,90 & 73,04 & & .17 \\
\hline 18 & Camar & SAR & $\begin{array}{l}110.03 \\
103.15\end{array}$ & $\begin{array}{l}10871 \\
104.51\end{array}$ & $\begin{array}{l}112,46 \\
103,23\end{array}$ & $\begin{array}{l}111,05 \\
103,46\end{array}$ & $\begin{array}{l}108,17 \\
104.61\end{array}$ & $\begin{array}{l}111,61 \\
107,63\end{array}$ & 0.06 & & & $\begin{array}{l}84,46 \\
83,49\end{array}$ & $\begin{array}{l}76,33 \\
75,01\end{array}$ & & 18,630 \\
\hline 19 & Cepu & 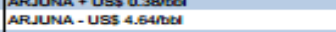 & 98,13 & 99,49 & 98,21 & 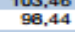 & $\begin{aligned} 99.61 \\
99.59\end{aligned}$ & $\begin{array}{l}102,61 \\
102\end{array}$ & 99,11 & 94,10 & 89.,48 & $\begin{array}{l}88,49 \\
78,47\end{array}$ & 69.99 & 54.50 & 90,18 \\
\hline 20 & Geragai & sic + Uss $0.1950 \mathrm{~d}$ & 110.22 & 108.90 & 112,65 & 111,24 & 108.36 & 111,80 & 105,25 & 100,19 & 95,85 & 84,65 & 76,52 & 60.19 & 18,82 \\
\hline 21 & Geragai C & ARC - USG & $\begin{array}{l}102,21 \\
10929\end{array}$ & $\begin{array}{l}100,11 \\
10428\end{array}$ & $\begin{array}{r}99,82 \\
103,00\end{array}$ & $\begin{array}{l}101,73 \\
10923\end{array}$ & $\begin{array}{l}103,05 \\
104,38\end{array}$ & $\begin{array}{l}103,91 \\
107,40\end{array}$ & & & $\begin{array}{l}92,19 \\
94,27\end{array}$ & $\begin{array}{l}77,63 \\
83.26\end{array}$ & $\begin{array}{l}69,60 \\
74,78\end{array}$ & & 92,06 \\
\hline & & 1550.1515000 & & & 11 & 10 & & 30 & $\begin{array}{l}103,90 \\
105,25\end{array}$ & & & 65 & & & 8,87 \\
\hline 24 & Jatbarane & sic & 110.03 & 108,71 & 112,46 & 111,05 & 108,17 & 111,61 & 105,06 & 100,00 & & $\begin{array}{l}84,46 \\
84,46\end{array}$ & 76,33 & 60.00 & $\begin{array}{l}98,68 \\
98,63\end{array}$ \\
\hline 25 & Jene / Pendopo & & 110.03 & 108.71 & 112,46 & 111,05 & 108,17 & 111,61 & 105,06 & 100,00 & 95.66 & 84,46 & 76,33 & 60.00 & 98,63 \\
\hline & & SIC+ + USS 0.4000A & $\begin{array}{l}110,43 \\
10226\end{array}$ & $\begin{array}{l}109.11 \\
10973\end{array}$ & $\begin{array}{l}112,86 \\
108,45\end{array}$ & & & & & $\begin{array}{r}100,40 \\
102,72\end{array}$ & & $\begin{array}{l}84,86 \\
87,37\end{array}$ & & & $\begin{array}{l}99.03 \\
9929\end{array}$ \\
\hline 28 & Klamon & DUA & 102,30 & 103.52 & 104,26 & 100,94 & 103.96 & 106,36 & 102,97 & 98,15 & 35 | & 81,90 & 04 & 54 & 17 \\
\hline 29 & SLT & & & & 101,11 & 101,34 & 102,49 & $105_{-}>>+>$ & & & & 8 & & & $\begin{array}{l}94,08 \\
93,08\end{array}$ \\
\hline 30 & Latang & sLC & 110.08 & 108.76 & 112,51 & 111,10 & 108.22 & 111,66 & & 100.05 & & & & & 68 \\
\hline 年1 & |Link" & & $\begin{array}{l}105,49 \\
10992\end{array}$ & $\begin{array}{l}106,90 \\
1086\end{array}$ & $\begin{array}{l}105,80 \\
112,35\end{array}$ & $\begin{array}{l}106,04 \\
110,94\end{array}$ & $\begin{array}{l}107.37 \\
108.06\end{array}$ & $\begin{array}{l}109,96 \\
111,50\end{array}$ & & & & $\begin{array}{l}85,66 \\
84.35\end{array}$ & 77,19 & & $\begin{array}{l}97.56 \\
98.52\end{array}$ \\
\hline 33 & Mactur & & & & 102,98 & 10 & & & & & & & & & \\
\hline 34 & Mengope & sLC+ + Uss 0.1950, & 110.22 & 108,90 & 112,65 & 111,24 & 108.36 & 111,80 & 105,25 & 100,19 & 85 & 84,65 & 76,52 & 60.19 & 98,82 \\
\hline $\begin{array}{l}35 \\
36\end{array}$ & 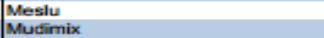 & s & $\begin{array}{l}10 \\
10\end{array}$ & $\begin{array}{l}104.13 \\
100.83\end{array}$ & $\begin{array}{l}103,03 \\
102,55\end{array}$ & $\begin{array}{l}10 \\
10 \\
10\end{array}$ & $\begin{array}{l}104,60 \\
103.93\end{array}$ & $\begin{array}{l}107,19 \\
108.65\end{array}$ & $\begin{array}{l}103,75 \\
103.45\end{array}$ & $g$ & 99 & $\begin{array}{l}82 \\
82\end{array}$ & $\begin{array}{l}74,42 \\
74,33\end{array}$ & $\begin{array}{l}58.96 \\
58.84 \\
\end{array}$ & $\begin{array}{l}94,79 \\
94.52\end{array}$ \\
\hline & & & & & & & & & & & & & & & \\
\hline 38 & $P_{2}$ & DONDENSATE & 105,68 & 106.87 & 105,66 & 106,14 & 107,54 & 109.65 & & 10 & & & & & 50 \\
\hline 39 & & & 11 & & & & 10 & $111, \pi 17$ & & & & & & & 73 \\
\hline & Pangk & 30/6 & & & & & & & & & & & & & .52 \\
\hline $\begin{array}{l}41 \\
42\end{array}$ & \begin{tabular}{|l} 
Ramb \\
Rimas
\end{tabular} & 01 & & & $\begin{array}{l}112 \\
112 \\
\end{array}$ & $\begin{array}{l}11 \\
11\end{array}$ & 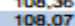 & 111, 11,51 & & & & & & & 1.82 \\
\hline 43 & s: & & & & & & & & & & & & & & 63 \\
\hline 44 & Setat Panjang & s & 110,03 & 108,71 & $112>2>2$ & 111,05 & 7 & 11 & & & & & & & 63 \\
\hline $\begin{array}{l}45 \\
46\end{array}$ & $\begin{array}{l}\text { Se } \\
\text { So }\end{array}$ & $A T=0$ & 10 & & 10 & 28 & 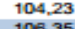 & 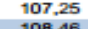 & & & & & & 59,14 & 94,82 \\
\hline & 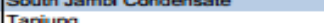 & ATE-C & 110 & & 104 & 11. & & 11 & & & & & & & $\begin{array}{l}96,31 \\
98,82\end{array}$ \\
\hline 48 & & & 101,24 & 102,60 & 101.32 & 101,55 & 102,70 & 105,72 & & 97,21 & & 81,58 & 10 & & 13.29 \\
\hline 49 & Trak & & 9 & & 101 & & 101,46 & & & & & & 54 & & .67 \\
\hline & & Is 3 & & & & & & & & & & & & & 98,71 \\
\hline & Wes & 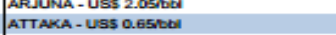 & 105.24 & 106,65 & 105,55 & 105,79 & 107.12 & 109.71 & 106,27 & 101,16 & 96,44 & 85,41 & 6,94 & 61,48 & $\begin{array}{l}92,77 \\
97,31\end{array}$ \\
\hline & Aver & & 105,80 & 106,08 & 106,90 & 106,44 & 106.20 & 108,95 & 104,63 & 99.51 & 94.97 & 83,72 & 75,39 & 59.56 & $6,5.5$ \\
\hline
\end{tabular}


Lampiran 11

\section{KONVERSI SATUAN ENERGI}

\begin{tabular}{|c|c|c|c|c|c|c|c|}
\hline \multirow[b]{2}{*}{ Konversi dari } & \multicolumn{7}{|c|}{ Pengali } \\
\hline & TCE & $\mathrm{BOE}$ & TOE & Joule & kalori & BTU & kWh \\
\hline TCE & 1 & 4,92 & 0,684 & $2,93^{*} 10^{+04}$ & $7,00 * 10^{+09}$ & $2,78^{*} 10^{+07}$ & $8,13^{*} 10^{+03}$ \\
\hline $\mathrm{BOE}$ & 0,203 & 1 & 0,139 & $5,95^{*} 10^{+09}$ & $1,46^{*} 10^{+09}$ & $5,64 * 10^{+06}$ & $1,70^{*} 10^{+03}$ \\
\hline TOE & 1,46 & 7,20 & 1 & $4,28 * 10^{+10}$ & $1,02 * 10^{+10}$ & $4,06 * 10^{+07}$ & $1,19^{*} 10^{+04}$ \\
\hline Joule & $3,45^{*} 10^{.11}$ & $1,68 * 10^{10}$ & $2,33^{*} 10^{11}$ & 1 & 0,239 & $9,48 * 10^{04}$ & $2,78^{*} 10^{07}$ \\
\hline kalori & $1,42^{*} 10^{10}$ & $6,84^{*} 10^{10}$ & $9,78^{*} 10^{11}$ & 4,18 & 1 & $3,97^{*} 10^{03}$ & $1,16^{*} 10^{06}$ \\
\hline BTU & $3,60^{*} 10^{\circ 0}$ & $1,77^{*} 10^{07}$ & $2,47^{*} 10^{08}$ & $1,06^{*} 10^{+03}$ & 252 & 1 & $2,93^{*} 10^{04}$ \\
\hline kWh & $1,23^{*} 10^{04}$ & $5,89 * 10^{\circ 4}$ & $8,41^{*} 10^{05}$ & $3,60^{*} 10^{+06}$ & $8,60^{*} 10^{+05}$ & $3,41^{*} 10^{+03}$ & 1 \\
\hline
\end{tabular}

Catatn:

TCE bn coal equivalent (acuam: $7000 \mathrm{kcal} / \mathrm{kg}$ )

BOE bamel oil equivalent (acugm: $10230 \mathrm{kcalkg} 32 \mathrm{APL}, 7.195 \mathrm{bgrmel} / \mathrm{pm})$

bic

BTU british themal unit

kWh kilo watt hour 
Lampiran 12

Data Kependudukan

\begin{tabular}{|c|c|c|c|}
\hline \multicolumn{1}{|c|}{ Rincian } & Tahun 2011 & Tahun 2012 & Tahun 2013 \\
\hline Jumlah Penduduk (Ribu Jiwa) & 8.156 & 8.250 & 8.342 \\
\hline Laki-laki & 3.978 & 4.025 & 4.071 \\
\hline Perempuan & 4.178 & 4.225 & 4.271 \\
\hline Sex Ratio (\%) & 95,20 & 95,27 & 95,34 \\
\hline Pertumbuhan Penduduk (\%) & 1,19 & 1,15 & 1,12 \\
\hline Kepadatan Penduduk (jiwa/km $\left.{ }^{2}\right)$ & 177 & 179 & 181 \\
\hline
\end{tabular}

Data Ekonomi Sulawesi Selatan

\begin{tabular}{|c|c|c|c|}
\hline Tahun & $\begin{array}{c}\text { PDRB per Kapita atas } \\
\text { Harga Konstan (Ribu } \\
\text { Rupiah) }\end{array}$ & $\begin{array}{c}\text { PDRB atas harga } \\
\text { konstan (Milyar } \\
\text { Rupiah) }\end{array}$ & $\begin{array}{c}\text { Pertumbuhan PDRB } \\
\text { atas dasar harga } \\
\text { konstan (\%) }\end{array}$ \\
\hline 2010 & 21.307 & 171,741 & 8,19 \\
\hline 2011 & 22.769 & 185,708 & 7,61 \\
\hline 2012 & 24.507 & 202,185 & 8,39 \\
\hline 2013 & 26.817 & 217,618 & 7,65 \\
\hline 2014 & 27.899 & 234,084 & 7,29 \\
\hline
\end{tabular}


Lampiran 13

Pemakaian Energi Jenis BBM

\begin{tabular}{|c|c|c|c|}
\hline Tahun & $\begin{array}{c}\text { Premium } \\
\text { (Metric Ton) }\end{array}$ & $\begin{array}{c}\text { Solar } \\
\text { (Metric Ton) }\end{array}$ & (Metric Ton) \\
\hline 2009 & 678,029 & 311,397 & 3,224 \\
\hline 2010 & 737,734 & 322,499 & 4,253 \\
\hline 2011 & 831,821 & 376,081 & 3,305 \\
\hline 2012 & 924,844 & 409,932 & 3,823 \\
\hline 2013 & 959,591 & 425,972 & 4,850 \\
\hline 2014 & 988,665 & 440,233 & 6,807 \\
\hline
\end{tabular}

Sumber : ( Pertamina, 2014)

Pembangkit Listrik Tenaga Air Sulawesi Selatan

\begin{tabular}{|l|c|c|}
\hline Kabupaten & Daya terpasang (MW) & Jumlah lokasi PLTA \\
\hline Pinrang & 443,0 & 3 \\
\hline Tana Toraja & 360,0 & 2 \\
\hline Enrekang & 656,0 & 5 \\
\hline Maros & 17,3 & 1 \\
\hline Gowa & 20,0 & 1 \\
\hline Luwu & 240,8 & 2 \\
\hline Sidrap & 494,1 & 1 \\
\hline Soppeng & 227,4 & 2 \\
\hline Jeneponto & 13,2 & 1 \\
\hline LuwuTimur & 475,0 & 19 \\
\hline J u m l a h & $2.946,8$ & 1 \\
\hline
\end{tabular}

Sumber : (ESDM Sulawesi Selatan, 2014) 
Lampiran 14

Pembangkit Listrik Tenaga Mini-Hidro Sulawesi Selatan

\begin{tabular}{|l|c|c|}
\hline Kabupaten & Daya terpasang $(\mathrm{kW})$ & Jumlah lokasi PLTM \\
\hline Enrekang & 435 & 1 \\
\hline Soppeng & 17200 & 2 \\
\hline Luwu & 1337 & 1 \\
\hline Bulukumba & 250 & 1 \\
\hline Sinjai & 11170 & 2 \\
\hline Tana Toraja & 8700 & 1 \\
\hline Bone & 1090 & 1 \\
\hline Gowa & 9200 & 1 \\
\hline Maros & 6000 & 1 \\
\hline Barru & 315 & 1 \\
\hline Wajo & 2700 & 1 \\
\hline Jeneponto & 9000 & 1 \\
\hline Bantaeng & 330 & 1 \\
\hline Luwu Timur & 8090 & 1 \\
\hline Pinrang & 600 & 18 \\
\hline J u m l a h & 76417 & $2014)$ \\
\hline
\end{tabular}

Sumber:(ESDM Sulawesi Selatan, 2014) 
Lampiran 15

PLTS Sulawesi Selatan

\begin{tabular}{|l|l|c|}
\hline No & \multicolumn{1}{|c|}{ Kabupaten } & Jumlah Unit \\
\hline 1 & Bantaeng & 352 \\
\hline 2 & Enrekang & 510 \\
\hline 3 & Wajo & 761 \\
\hline 4 & Soppeng & 450 \\
\hline 5 & Takalar & 553 \\
\hline 6 & Pinrang & 432 \\
\hline 7 & Tana Toraja/Toraja Utara & 803 \\
\hline 8 & Jeneponto & 600 \\
\hline 9 & Bulukumba & 543 \\
\hline 10 & Gowa & 750 \\
\hline 11 & Lutim & 338 \\
\hline 12 & Palopo & 320 \\
\hline 13 & Lutra & 465 \\
\hline 14 & Barru & 345 \\
\hline 15 & Pangkep & 703 \\
\hline 16 & Maros & 620 \\
\hline 17 & L u w u & 1420 \\
\hline 18 & B o n e & 936 \\
\hline 19 & Selayar & 2.45 \\
\hline 20 & Sidrap & 285 \\
\hline 21 & Sinjai & 553 \\
\hline & & Jumlah \\
\hline & & \\
\hline
\end{tabular}


Lampiran 16

Potensi Biodiesel Sulawesi Selatan

\begin{tabular}{|c|l|c|c|}
\hline No. & \multicolumn{1}{|c|}{$\begin{array}{c}\text { Jenis Bahan } \\
\text { baku }\end{array}$} & $\begin{array}{c}\text { Potensi } \\
(\text { Ha })\end{array}$ & $\begin{array}{c}\text { Produktiv.Minyak } \\
\text { (Liter/ha/Thn) }\end{array}$ \\
\hline 1 & Jagung & 262.436 & 172 \\
\hline 2 & Kapas & 3305 & 325 \\
\hline 3 & Kacang Tanah & 34001 & 1059 \\
\hline 4 & Kelapa & 114300 & 2689 \\
\hline 5 & Kelapa sawit & 7950 & 5950 \\
\hline 6 & Jarak Pagar & 800 & 2300 \\
\hline & Total & 601.992 & 12.495 \\
\hline
\end{tabular}

Sumber : ESDM Sulawesi Selatan, 2014

Potensi Bioetanol Sulawesi Selatan

\begin{tabular}{|c|l|c|c|}
\hline No. & Jenis Bahan Baku & Potensi (Ha) & $\begin{array}{c}\text { Produktiv.Minyak } \\
\text { (Liter/ha/Thn) }\end{array}$ \\
\hline 1 & Ubi kayu & 32.852 & 4.5 \\
\hline 2 & Ubi Jalar & 5.029 & 7.812 \\
\hline 3 & Tebu & 2.819 & 5.025 \\
\hline \multicolumn{2}{|l|}{ Total } & 40.700 & 17.337 \\
\hline
\end{tabular}

Sumber:(ESDM Sulawesi Selatan, 2014) 
Lampiran 17

Potensi Biogas Sulawesi Selatan

\begin{tabular}{|c|l|c|c|c|c|}
\hline No. & Kab/Kota & $\begin{array}{c}\text { Sapi Potong } \\
\text { (Ekor) }\end{array}$ & $\begin{array}{c}\text { Sapi Perah } \\
\text { (Ekor) }\end{array}$ & $\begin{array}{c}\text { Kerbau } \\
\text { (Ekor) }\end{array}$ & $\begin{array}{c}\text { Potensi Biru } \\
\text { (Digester) }\end{array}$ \\
\hline 1 & Selayar & 13.135 & 3 & 4.004 & 4.286 \\
\hline 2 & Bulukumba & 53.491 & 5 & 1.426 & 13.731 \\
\hline 3 & Bantaeng & 18.938 & 4 & 197 & 4.785 \\
\hline 4 & Jenneponto & 19.287 & - & 3.184 & 5.618 \\
\hline 5 & Takalar & 34.987 & - & 3.597 & 9.646 \\
\hline 6 & Gowa & 88.778 & 54 & 1.361 & 22.548 \\
\hline 7 & Sinjai & 74.187 & 211 & 1.005 & 18.851 \\
\hline 8 & Maros & 58.303 & - & 1.760 & 15.016 \\
\hline 9 & Pangkep & 33.214 & - & 2.627 & 8.960 \\
\hline 10 & Barru & 53.201 & 2 & 346 & 13.387 \\
\hline 11 & Bone & 275.571 & 3 & 3.643 & 69.804 \\
\hline 12 & Soppeng & 26.951 & 5 & 64 & 6.755 \\
\hline 13 & Wajo & 72.066 & - & 4.472 & 19.135 \\
\hline 14 & Sidrap & 33.964 & 3 & 2.110 & 9.019 \\
\hline 15 & Pinrang & 20.936 & 23 & 2.324 & 5.821 \\
\hline 16 & Enrekang & 42.107 & 1.362 & 3.489 & 11.740 \\
\hline 17 & Luwu & 13.518 & - & 6.026 & 4.886 \\
\hline 18 & Tana Toraja & 5.823 & - & 21.861 & 6.921 \\
\hline 19 & Luwu Utara & 22.874 & 3 & 11.542 & 8.605 \\
\hline 20 & Luwu Timur & 14.232 & - & 1.110 & 3.836 \\
\hline 21 & Toraja Utara & 199 & - & 19.373 & 4.893 \\
\hline 22 & Makassar & 2.742 & 9 & 356 & 777 \\
\hline 23 & Parepare & 3.519 & 3 & 83 & 901 \\
\hline 24 & Palopo & 1.962 & - & 545 & 627 \\
\hline J U M L A H & 983.985 & 1.690 & 96.505 & 270.545 \\
\hline & & & & & \\
\hline
\end{tabular}


Lampiran 18

Potensi Biomassa Sulawesi Selatan

\begin{tabular}{|r|l|r|}
\hline No & Jenis Biomassa & Jumlah Energi (Kcal) \\
\hline 1 & Sekam Padi & 327.453 .734 .384 \\
\hline 2 & Bonggol jagung & 1.760 .316 .201 .144 \\
\hline 3 & Ubi Kayu & 1.006 .809 .102 .824 \\
\hline 4 & Kelapa Sawit & 91.993 .607 .091 \\
\hline 5 & Bagas & 38.063 .697 .628 \\
\hline
\end{tabular}

Sumber: (Nurmawati, 2009)

Pemakaian Energi Jenis Listrik tahun 2012-2014

\begin{tabular}{|c|c|c|c|c|c|c|c|}
\hline \multirow{2}{*}{$\begin{array}{l}\text { GOLONGAN } \\
\text { TARIF }\end{array}$} & \multirow{2}{*}{$\begin{array}{l}\text { Ting } \\
\text { kat }\end{array}$} & \multicolumn{2}{|c|}{ Tahun 2012} & \multicolumn{2}{|c|}{ Tahun 2013} & \multicolumn{2}{|c|}{ Tahun 2014} \\
\hline & & KWH & KVARH & KWH & KVARH & KWH & KVARH \\
\hline S.1 / 220 VA & - & 0 & 0 & 0 & 0 & 72 & 0 \\
\hline \multirow{3}{*}{ S.2 / 450 VA } & 1 & 1.572 .213 & 0 & 1.442 .636 & 0 & 1.420 .015 & 0 \\
\hline & II & 892.168 & 0 & 896.054 & 0 & 882.095 & 0 \\
\hline & III & 1.655 .237 & 0 & 1.837 .445 & 0 & 1.931 .623 & 0 \\
\hline \multirow{3}{*}{ S.2 / 900 VA } & 1 & 3.130 .527 & 0 & 3.590 .415 & 0 & 4.603 .487 & 0 \\
\hline & $\|$ & 3.456 .863 & 0 & 3.719 .977 & 0 & 3.720 .483 & 0 \\
\hline & III & 6.747 .638 & 0 & 7.860 .720 & 0 & 8.215 .327 & 0 \\
\hline S.2/ 1.300 VA & - & 9.560 .330 & 0 & 10.574 .273 & 0 & 11.247 .002 & 0 \\
\hline S.2 / $2.200 \mathrm{VA}$ & - & 9.294 .688 & 0 & 10.563 .190 & 0 & 11.330 .016 & 0 \\
\hline $\begin{array}{l}\mathrm{S} .2 / 3.500 \mathrm{VA} \\
\mathrm{s} / \mathrm{d} 200 \mathrm{kVA} \\
\end{array}$ & - & 64.734 .267 & 0 & 76.877 .565 & 0 & 86.305 .671 & 0 \\
\hline S. $3>200 \mathrm{Kva}$ & - & 37.009 .516 & 128.321 & 50.581 .441 & 254.506 & 56.778 .491 & 356.932 \\
\hline $\begin{array}{l}\text { JUMLAH S } \\
\text { (Sosial) }\end{array}$ & & 138.053 .446 & 128.321 & 167.943.716 & 254.506 & 186.434 .282 & 356.932 \\
\hline \multirow{3}{*}{ R.1 / 450 VA } & 1 & 214.794 .300 & 0 & 200.251 .745 & 0 & 204.364 .935 & 0 \\
\hline & $॥$ & 145.052 .405 & 0 & 150.029 .824 & 0 & 152.129 .500 & 0 \\
\hline & III & 197.192.069 & 0 & 238.167 .172 & 0 & 261.590 .390 & 0 \\
\hline \multirow{3}{*}{ R.1 / 900 VA } & 1 & 262.896 .733 & 0 & 267.721 .150 & 0 & 386.752 .438 & 0 \\
\hline & ॥ & 248.428 .796 & 0 & 278.107 .509 & 0 & 283.290 .600 & 0 \\
\hline & III & 470.687 .755 & 0 & 584.014 .485 & 0 & 627.446 .932 & 0 \\
\hline R.1/1.300 VA & - & 403.006 .050 & 0 & 463.344 .645 & 0 & 500.179 .421 & 0 \\
\hline
\end{tabular}




\begin{tabular}{|c|c|c|c|c|c|c|c|}
\hline \multirow{2}{*}{$\begin{array}{l}\text { GOLONGAN } \\
\text { TARIF }\end{array}$} & \multirow{2}{*}{$\begin{array}{l}\text { Ting } \\
\text { kat }\end{array}$} & \multicolumn{2}{|c|}{ Tahun 2012} & \multicolumn{2}{|c|}{ Tahun 2013} & \multicolumn{2}{|c|}{ Tahun 2014} \\
\hline & & KWH & KVARH & KWH & KVARH & KWH & KVARH \\
\hline $\begin{array}{l}\text { R.2 / 3.500 VA } \\
\text { s/d 5.500 VA }\end{array}$ & - & 74.885 .850 & 0 & 89.889 .782 & 0 & 99.348 .679 & 0 \\
\hline \multirow{2}{*}{$\begin{array}{l}\text { R.3 / } 6.600 \text { VA } \\
\text { keatas }\end{array}$} & 1 & 15.335 .107 & 0 & 19.765 .033 & 0 & 38.038 .689 & 0 \\
\hline & ॥ & 15.092 .422 & 0 & 16.170 .414 & 0 & 0 & 0 \\
\hline $\begin{array}{c}\text { JUMLAH R } \\
\text { (Rumah } \\
\text { Tangga) } \\
\end{array}$ & & 2.257 .760 .560 & 0 & 2.548 .354 .051 & 0 & 2.810 .134 .468 & 0 \\
\hline \multirow{2}{*}{ B. 1 / 450 VA } & 1 & 1.816 .585 & 0 & 1.694 .863 & 0 & 1.685 .313 & 0 \\
\hline & $\|$ & 3.998 .235 & 0 & 4.097.164 & 0 & 3.994 .079 & 0 \\
\hline \multirow{2}{*}{ B.1 / 900 VA } & 1 & 16.147 .446 & 0 & 16.696 .752 & 0 & 19.131 .390 & 0 \\
\hline & $\|$ & 12.890 .569 & 0 & 14.147 .708 & 0 & 13.867 .075 & 0 \\
\hline B. $1 / 1.300$ VA & - & 40.841 .111 & 0 & 42.698 .576 & 0 & 43.281 .390 & 0 \\
\hline $\begin{array}{l}\text { B.1 / } 2.200 \text { VA } \\
\text { s/d 5.500 VA }\end{array}$ & - & 147.097 .901 & 0 & 154.805 .805 & 0 & 168.176 .755 & 0 \\
\hline \multirow{2}{*}{$\begin{array}{l}\text { B. } 2 / 6.600 \text { VA } \\
\text { s/d } 200 \text { kVA }\end{array}$} & 1 & 209.799 .985 & 0 & 205.720 .423 & 73 & 456.782 .246 & 0 \\
\hline & ॥ & 147.629 .488 & 0 & 160.353 .355 & 0 & 628 & 0 \\
\hline B. $3 />200 \mathrm{kVA}$ & - & 243.120 .037 & 4.000 .094 & 273.087 .513 & 6.458 .139 & 298.881 .302 & -1.844 .936 \\
\hline $\begin{array}{c}\text { JUMLAH B } \\
\text { (Bisnis) }\end{array}$ & & 823.341.358 & 4.000 .094 & 873.302 .159 & 6.458 .212 & 1.005 .800 .178 & -1.844 .936 \\
\hline \multirow{2}{*}{$\mathrm{I} .1$ / $450 \mathrm{VA}$} & 1 & 1.251 & 0 & 1.08 & 0 & 1.052 & 0 \\
\hline & $\|$ & 3.898 & 0 & 3.912 & 0 & 4.781 & 0 \\
\hline \multirow{2}{*}{$\mathrm{I} .1 / 900 \mathrm{VA}$} & 1 & 39.368 & 0 & 36.838 & 0 & 38.073 & 0 \\
\hline & $\|$ & 41.147 & 0 & 40.835 & 0 & 47.678 & 0 \\
\hline I.1/1.300 VA & - & 107.326 & 0 & 121.062 & 0 & 92.417 & 0 \\
\hline $1.1 / 2.200$ VA & - & 189.277 & 0 & 170.313 & 0 & 160.345 & 0 \\
\hline $\begin{array}{c}\mathrm{I} .1 / 3.500 \mathrm{~s} / \mathrm{d} \\
14 \mathrm{kVA}\end{array}$ & - & 2.481 .097 & 0 & 2.721 .515 & 0 & 2.546 .819 & 0 \\
\hline $\begin{array}{l}\mathrm{I} .2 />14 \mathrm{kVA} \\
\mathrm{s} / \mathrm{d} 200 \mathrm{kVA}\end{array}$ & - & 118.285 .830 & 4.561 .121 & 127.459 .558 & 6.518 .826 & 142.378 .256 & 3.728 .293 \\
\hline $1.3 />200 \mathrm{kVA}$ & - & 239.957 .851 & 4.119 .258 & 263.862 .254 & 9.730 .734 & 304.360 .524 & 3.311 .176 \\
\hline $\begin{array}{l}\text { I.4 / } 30.000 \\
\text { kVA keatas }\end{array}$ & - & 421.317 .273 & 1.726 .380 & 375.751 .639 & 0 & 365.174 .834 & 0 \\
\hline $\begin{array}{l}\text { JUMLAH I } \\
\text { (Industri) }\end{array}$ & & 782.424.318 & 10.406 .759 & 770.169 .006 & 16.249 .560 & 814.804 .779 & 7.039 .469 \\
\hline P.1/450 VA & - & 599.324 & 0 & 668.78 & 0 & 673.639 & 0 \\
\hline P.1/900 VA & - & 2.312 .932 & 0 & 2.642 .797 & 0 & 2.901 .732 & 0 \\
\hline P. $1 / 1.300$ VA & - & 2.497.391 & 0 & 2.694 .932 & 0 & 2.799 .459 & 0 \\
\hline $\begin{array}{l}\text { P.1 / } 2.200 \text { VA } \\
\text { s/d 5.500 VA }\end{array}$ & - & 11.240 .028 & 0 & 12.710 .454 & 0 & 13.217.762 & 0 \\
\hline \multirow{2}{*}{$\begin{array}{l}\text { P.1 / } 6.600 \text { VA } \\
\text { s/d } 200 \text { kVA }\end{array}$} & 1 & 35.310 .869 & 0 & 46.754 .780 & 0 & 96.258 .893 & 0 \\
\hline & ॥ & 38.920 .948 & 8.538 & 40.800 .010 & 0 & 0 & 0 \\
\hline P. $2 />200 \mathrm{kVA}$ & - & 28.846 .327 & 282.462 & 30.545 .055 & 431.466 & 34.221 .477 & 209.006 \\
\hline P.3 & - & 132.974 .488 & 0 & 126.459 .378 & 0 & 132.418 .018 & 0 \\
\hline $\begin{array}{c}\text { JUMLAH P } \\
\text { (Pemerintah) }\end{array}$ & & 252.702.307 & 291 & 263.276.186 & 431.466 & 282.490 .980 & 209.006 \\
\hline $\mathrm{T} />200 \mathrm{kVA}$ & - & 0 & 0 & 0 & 0 & 0 & 0 \\
\hline $\begin{array}{c}\mathrm{C} / \mathrm{TM}>200 \\
\mathrm{kVA}\end{array}$ & - & 0 & 0 & 0 & 0 & 0 & 0 \\
\hline $\mathrm{L}$ & - & 91.384 .797 & 0 & 362.673 .853 & 0 & 148.286 .546 & 0 \\
\hline
\end{tabular}


Lampiran 19

Pembangkit Listrik Sulawesi Selatan

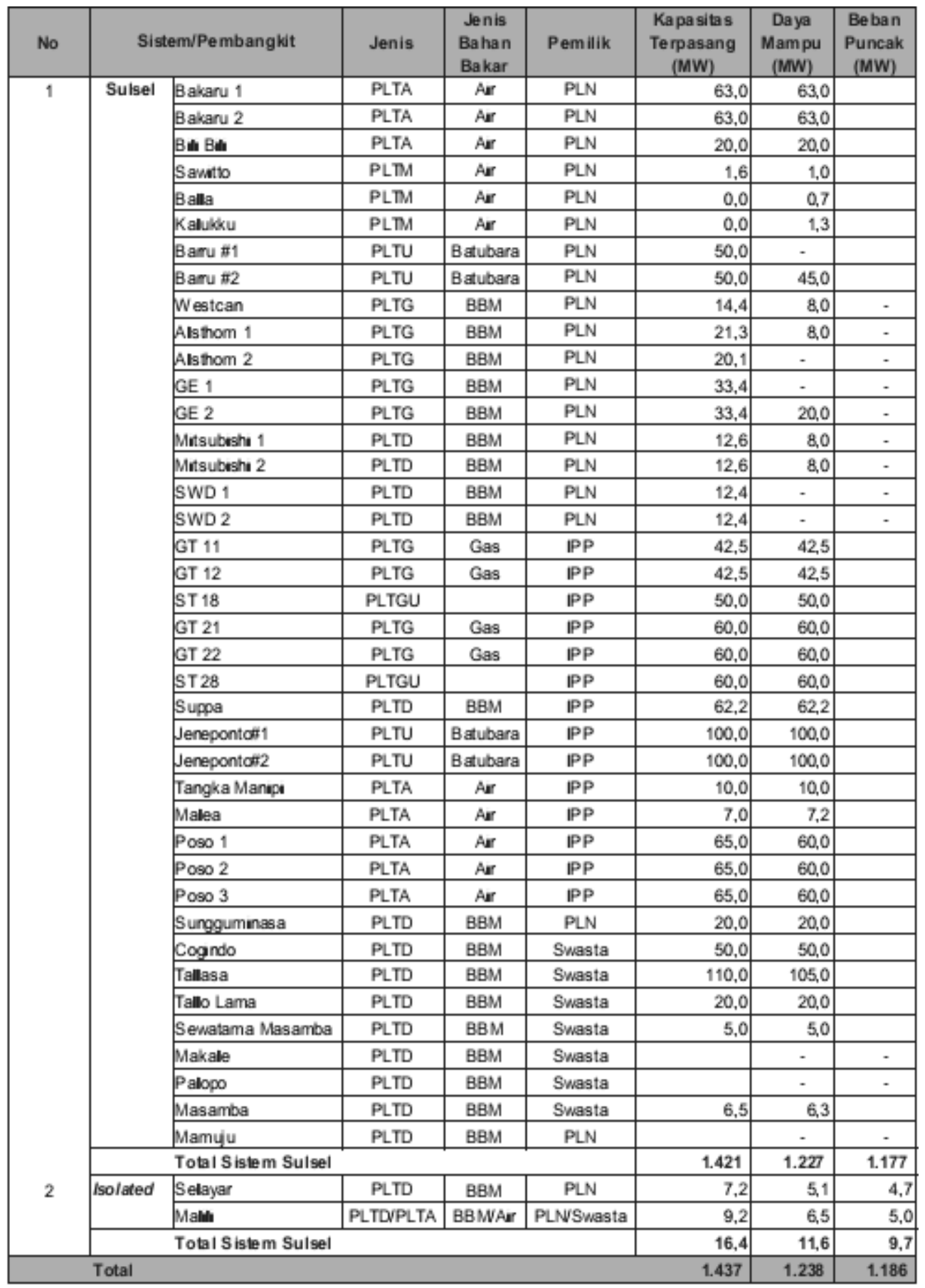

Sumber : PLN, 2014 
Lampiran 20

KONVERSI SATUAN ENERGI KE SBM

\begin{tabular}{|l|c|c|}
\hline \multicolumn{1}{|c|}{ Jenis Energi } & Unit Asli & Pengali ke SBM \\
\hline Batubara & Ton & 4,9893 \\
Antrasit & Ton & 4,2766 \\
Batubara Kalimantan & Ton & 4,8452 \\
Batubara Ombilin & Ton & 3,7778 \\
Batubara Tanjung Enim & Ton & 3,0649 \\
Lignit & Ton & 2,5452 \\
Gambut Ricu & Ton & 3,5638 \\
Briket Batubara & & \\
Biomasa & Ton & 4,9713 \\
Arang kayu & Ton & 2,2979 \\
Kayu Bakar & MSCF & 0,1796 \\
Gas bumi & M & 0,0063 \\
Gas bumi & Ribu KKal & 0,0007 \\
Gas Kota & Ribu KKal & 0,0007 \\
CNG & Ton & 8,0532 \\
LNG & MMBTU & 0,1796 \\
LNG & Ton & 8,5246 \\
LPG & & \\
Minyak Bumi & Barel & 0,9545 \\
Kondensat & Barel & 1,0000 \\
Minyak bumi & & \\
Produk Kilang & KiloLiter & 5,5530 \\
Aviation Gasoil (Avgas) & KiloLiter & 5,8907 \\
Aviation Turbin Gas & & \\
(Avtur) & KiloLiter & 5,8275 \\
Premium & KiloLiter & 5,9274 \\
Minyak Tanah (Kerosene) & KiloLiter & 6,4871 \\
Minyak Solar (ADO) & KiloLiter & 6,6078 \\
Minyak Diesel (IDO) & KiloLiter & 6,9612 \\
Minyak Bakar (FO) & Barel & 1,6728 \\
Refinery Fuel Gas (RFG) & Barel & 1,1236 \\
Refinery Fuel Oil (RFO) & MWh & 1,5937 \\
Panas Bumi & MWh & 1,5937 \\
Tenaga Air & MWh & 0,6130 \\
Listrik & & \\
\hline & & \\
\hline
\end{tabular}

Sumber. Departemen Pertambangan dan Energi 